\title{
ASPECTOS ETNOENTOMOLÓGICOS, SOCIOECONÔMICOS E ECOLÓGICOS RELACIONADOS À CULTURA DA ERVA-MATE (Ilex paraguariensis) NO MUNICÍPIO DE SALTO DO LONTRA, PARANÁ, BRASIL
}

\section{RAQUEL PASINATO}

Dissertação apresentada à Escola Superior de Agricultura "Luiz de Queiroz", Universidade de São Paulo, para obtenção do título de mestre em Ecologia de Agroecossistemas.

PIRACICABA

Estado de São Paulo - Brasil

Dezembro - 2003 


\title{
ASPECTOS ETNOENTOMOLÓGICOS, SOCIOECONÔMICOS E ECOLÓGICOS RELACIONADOS À CULTURA DA ERVA-MATE (Ilex paraguariensis) NO MUNICÍPIO DE SALTO DO LONTRA, PARANÁ, BRASIL
}

\author{
RAQUEL PASINATO \\ Bióloga
}

Orientador: Prof. Dr. VALTER ARTHUR

Dissertação apresentada à Escola Superior de Agricultura "Luiz de Queiroz", Universidade de São Paulo, para obtenção do título de Mestre Ecologia de Agroecossistemas.

PIRACICABA

Estado de São Paulo - Brasil

Dezembro - 2002 


\section{Dados Internacionais de Catalogação na Publicação (CIP)} DIVISÃO DE BIBLIOTECA E DOCUMENTAÇÃO - ESALQ/USP

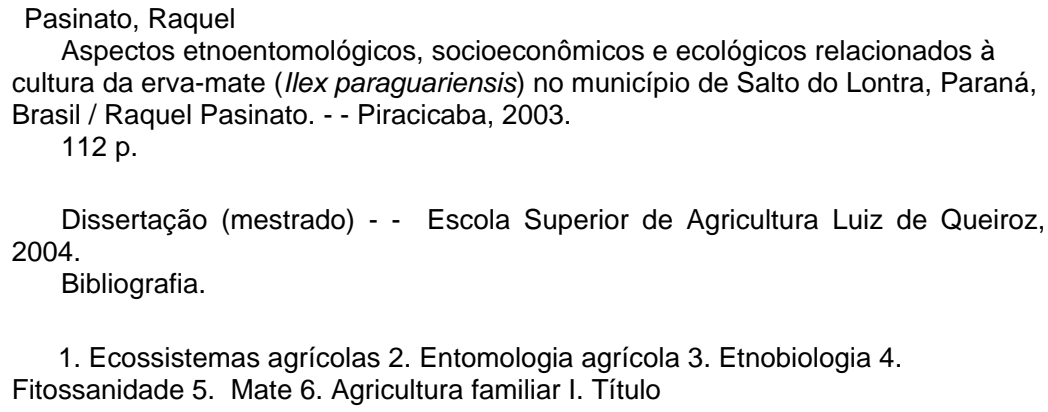

CDD 633.73

\section{"Permitida a cópia total ou parcial deste documento, desde que citada a fonte - $\mathrm{O}$ autor"}




\section{DEDICATÓRIA}

Dedico este trabalho aos meus amados pais, Tranqüilo Pasinato e Inedir Pasinato e aos meus queridos irmãos Cássio e Hígor. Com vocês dividi aflições, orações, intenções e sonhos. Alguns destes sonhos com o tempo se vão, outros porém, tornaram-se reais. A vocês toda minha conquista, por vocês toda fé na vida, para vocês todo meu amor.

Aos meus tios, Danilo Pasinato e Maria de Fátima Pasinato, com toda gratidão e carinho que merecem. Sem vocês eu teria desistido no caminho. 


\title{
Chimarrão
}

\author{
Amargo doce que eu sorvo \\ num beijo em lábios de prata \\ tens o perfume da mata \\ molhada pelo sereno. \\ e a cuia, seio moreno \\ que passa de mão em mão \\ traduz no meu chimarrão \\ em sua simplicidade \\ a velha hospitalidade \\ da gente do meu rincão
}

Glaucus Saraiva 


\section{AGRADECIMENTOS}

À uma força poderosa, que sempre abre novas janelas em minha vida, a quem muitos assim como eu, chamam de Deus, obrigada.

Ao meu orientador, professor Valter, pela liberdade de escolha que proporcionou e pelo apoio nas escolhas do caminho deste trabalho, obrigada.

À minha banca de qualificação, professora Maria Elisa Garavello e professor João Hoefel pelas valiosas contribuições na conclusão deste trabalho. Também ao professor Caron pelos diálogos esclarecedores.

Ao professor e amigo Luis F. Alves da Universidade Estadual do oeste do Paraná, por ter acreditado em mim, por sempre estar do meu lado e por ter sido meu primeiro exemplo de professor pesquisador, meu muito obrigada.

Ao professor Marcos Sorrentino, pelas vezes que me ouviu, apontou caminhos e principalmente por ter reacendido minha fé nas utopias, obrigada.

Aos amigos, Ana Paula e Andersão, obrigada pelo apoio em todos os momentos, pelas fossas curtidas juntos, pelas boas gargalhadas e principalmente pelo companheirismo e amizade sincera. Este momento de despedida é triste pela incerteza do amanhã, mas é fugaz pela esperança do reencontro. Levo vocês em meu coração. 
Á amiga Cláudia, que também compartilha esperanças, ideais e utopias, obrigada pelo conhecimento compartilhado, pela ajuda na construção deste trabalho de mestrado e no meu crescimento pessoal, sua amizade é muito especial para mim.

Aos amigos da Vila Estudantil da Pós-Graduação da ESALQ, Rosângela, Kátia, Henrique, Márcia, Milena, Juan, Wirifran, Daruska e Júlio, por todos os momentos compartilhados, foram intensos e inesquecíveis, assim como vocês.

Ao amigo Elio, que também veio passar um tempo em Pira, você é especial, obrigada pela contribuição na identificação dos insetos e, principalmente, pela amizade sincera.

Às amigas, Elaine, Francieli e Sheila, que mesmo distantes, ouviram, incentivaram e acreditaram, obrigada pela amizade duradoura, sei que vocês sempre estarão comigo, mesmo separadas pela distância geográfica.

Aos colegas da OCA, Ana Paula Coati, Valéria, Flávia, Sandra, Rita, Amílcar, Mário e Maria Cláudia, obrigada pela acolhida, apoio e pelos momentos compartilhados.

À dona Nair, pessoa que me acolheu em sua casa nos primeiros tempos em Pira, obrigada pelo carinho.

Á ESALQ, pela moradia estudantil, ao Programa de Pós Graduação Interunidades em Ecologia de Agroecossitemas, pela oportunidade do aprendizado. Ao departamento de Ciências Florestais pelo espaço disponibilizado. À Regina Freitas, secretaria da Ecologia, pela atenção, incentivo e apoio, obrigada.

Aos colegas do Coral Luiz de Queiroz, pela alegria compartilhada de cantar. 
Por fim, de maneira especial agradeço aos agricultores/as de Salto do Lontra, ao técnico da Secretaria Municipal de Agricultura, Adair Banck, ao Engoagrônomo Hiloy B. Santi , pela estrutura que possibilitou a realização desta pesquisa, meus sinceros agradecimentos. 


\section{SUMÁRIO}

Página

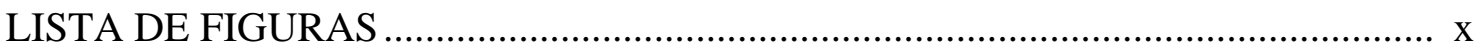

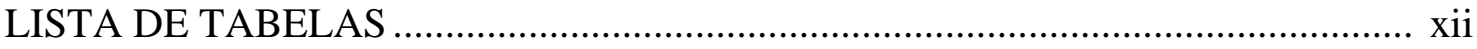

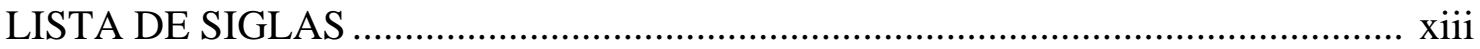

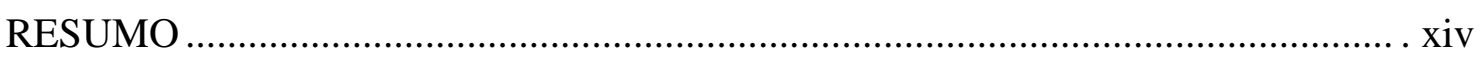

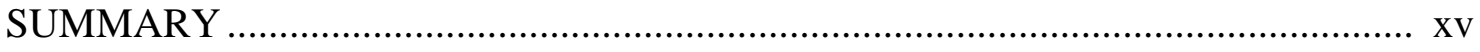

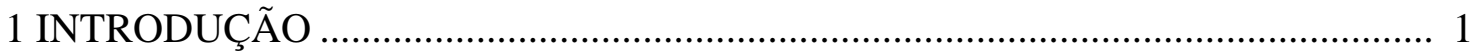

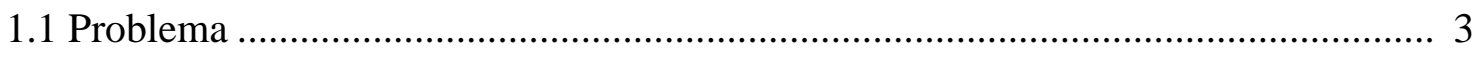

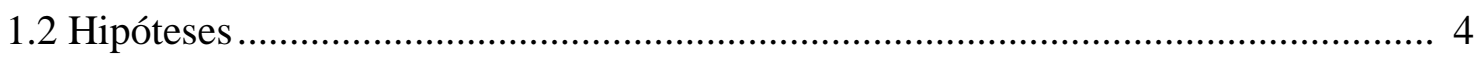

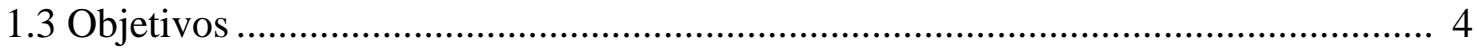

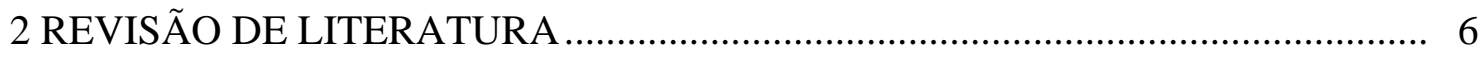

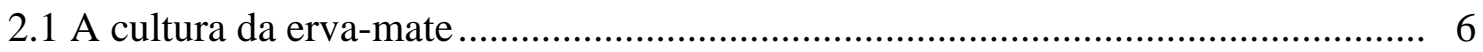

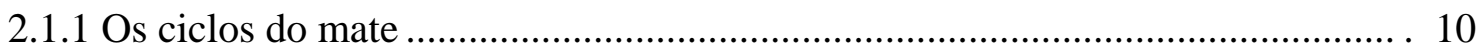

2.1.2 Características fenológicas da erva-mate .................................................... 12

2.1.3 Pragas da erva-mate, inimigos naturais e o equilíbrio ecológico do

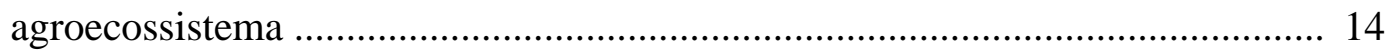

2.1.4 Aspectos culturais, políticos, sociológicos e econômicos da atividade ervateira

2.1.5 Organização dos agricultores familiares em relação à cultura da erva-mate no

Sul do Brasil: possibilidades emergentes...................................................... 22

2.2 Das mudanças na agricultura à busca de um novo paradigma.............................. 23

2.3 Estrutura da agricultura familiar do Paraná ....................................................... 28

2.4 Os saberes e os sabores: a importância do etnoconhecimento.............................. 32 
2.5 O ser humano e a natureza: caminhos apontados pela etnociência....................... 33

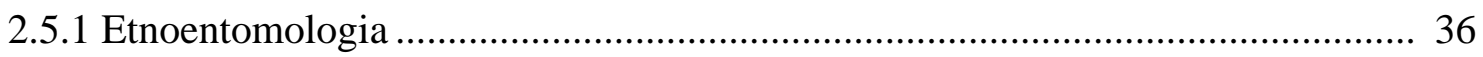

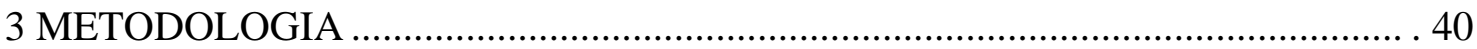

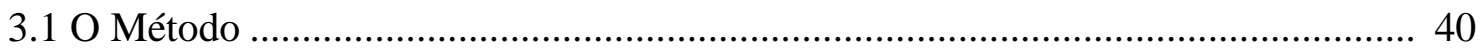

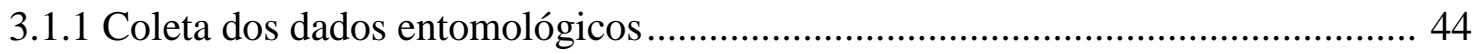

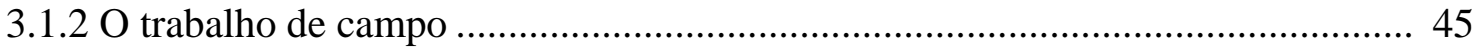

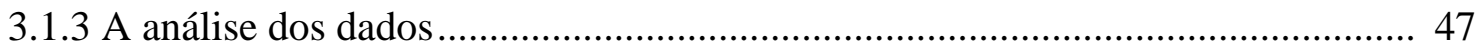

3.2 Caracterização da área de estudo: o município de Salto do Lontra ....................... 48

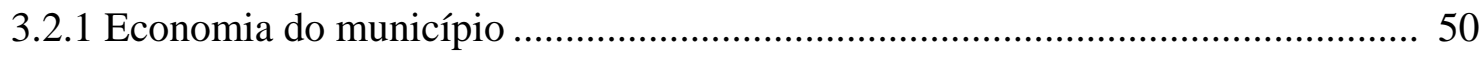

3.2.2 Estrutura Fundiária.............................................................................. 53

3.3 Caracterização dos sujeitos da pesquisa........................................................... 53

4 RESULTADOS E DISCUSSÂO .................................................................. 55

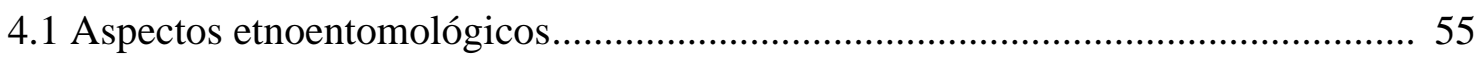

4.1.1 O etnoconhecimento do agricultor erveiro em relação aos insetos praga e

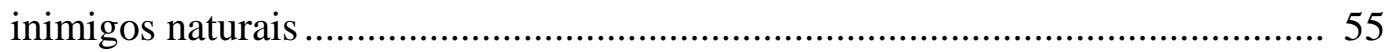

4.1.2 Relação estabelecida pelo agricultor com os insetos e a cultura da erva-

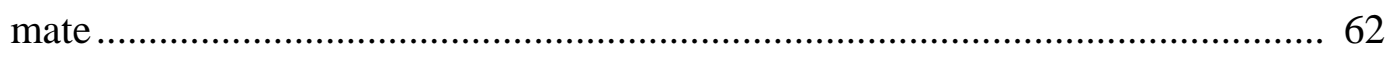

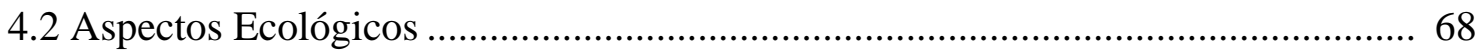

4.2.1 Ervais nativos, ervais plantados e sistemas ecologicamente sustentáveis ........... 68

4.2.2 Diversidade da entomofauna em ervais plantados no município de Salto do

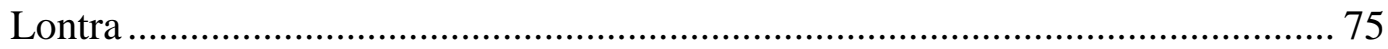

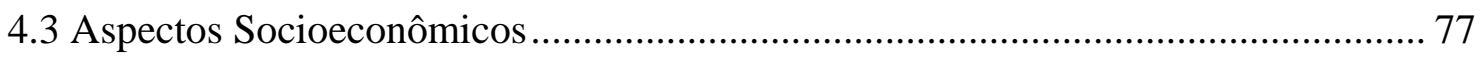

4.3.1 O município de Salto do Lontra e a cultura da erva-mate: como tudo

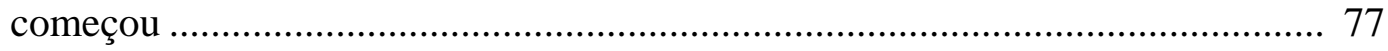

4.3.2 A erva-mate como alternativa de renda ....................................................... 80

4.3.3 A assistência técnica no campo e a organização dos agricultores ...................... 82

4.3.4 Os produtos derivados da erva-mate ........................................................... 86

4.3.5 O trabalho familiar no campo .............................................................. 88 
4.3.6 Perspectiva do agricultor sobre o futuro da erva-mate................................... 90

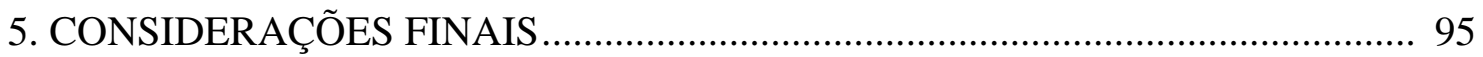

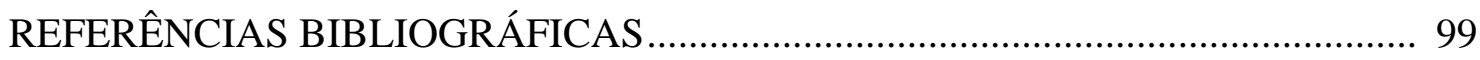




\section{LISTA DE FIGURAS}

Página

1 Mapa da localização geográfica da erva-mate no Brasil............................................ 13

2 Aplicações Industriais e Usos Alternativos para a Erva-Mate..................................... 88 


\section{LISTA DE TABELAS}

Página

1 Participação da agricultura familiar e da agricultura patronal no total de estabelecimentos e área segundo mesorregiões Paraná 1995 .................................... 30 2 Produção agrícola do Município de Salto do Lontra nos anos de 1994 a 2002 ........ 51 3 Estrutura fundiária do Município de Salto do Lontra ........................................... 53

4 Comparação entre o conhecimento popular dos agricultores sobre os insetos associados ou não com a erva-mate com a taxonomia e características apresentadas pela

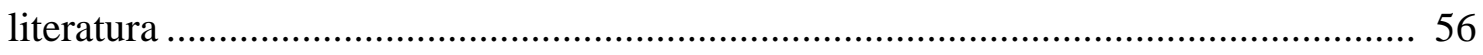

5 Comparação entre citações dos agricultores sobre os insetos (pragas e inimigos naturais) apresentados e pelas fotos e as considerações da literatura a respeito........... 59

6 Famílias de insetos coletadas nos dois ervais plantados no município de Salto do Lontra, PR. N= número de famílias de insetos, H’= índice de diversidade de ShannonWiener 


\section{LISTA DE SIGLAS}

APROMATE - Associação dos Produtores da erva-mate

CAMOL -Cooperativa Mista Ourense

CRESOL - Cooperativas de Crédito Rural

EMBRAPA - Empresa Brasileira de Pesquisa Agropecuária

EMATER - Empresa Paranaense de Assistência Técnica e Extensão Rural

FAPERGS - Fundação de Amparo à pesquisa do Rio grande do Sul

INCRA - Instituto Nacional de Terras e

ONGs - Organizações não governamentais

PRONAF - Programa Nacional de Fortalecimento da Agricultura Familiar

PRONEX - Programas de Apoio à Núcleos de Excelência

UNI-ERECHIM - Universidade Regional de Erechim

UNISC - Universidade Santa Cruz do Sul 


\title{
ASPECTOS ETNOENTOMOLÓGICOS, SOCIOECONÔMICOS E ECOLÓGICOS RELACIONADOS À CULTURA DA ERVA-MATE (Ilex paraguariensis) NO MUNICÍPIO DE SALTO DO LONTRA, PARANÁ, BRASIL
}

\author{
Autora: RAQUEL PASINATO \\ Orientador: Prof. Dr. VALTER ARTHUR
}

\section{RESUMO}

Esta pesquisa aconteceu com o objetivo de realizar um estudo etnoentomológico com os produtores de erva-mate do Município de Salto do Lontra, região Sudoeste do Paraná, visando diagnosticar parâmetros para um plano de manejo que viesse a contribuir para a solucionar problemas fitossanitários, socioeconômicos e ambientais enfrentados pelos agricultores do município. Assim, utilizando elementos da pesquisa qualitativa e da pesquisa quantitativa, como as entrevistas e as coletas de insetos, objetivou-se encontrar indicadores para as respostas ao problema da decadência da cultura da erva-mate em Salto do Lontra. O estudo buscou valorizar e compreender o etnoconhecimento do agricultor/a produtor/a de erva-mate, a respeito dos insetos que observam nas plantações desta cultura e as cognições que fazem sobre estes invertebrados. Observou-se que os agricultores identificam e conhecem mais os insetos classificando-os como benéficos ou maléficos à medida que estes causam danos às suas plantações. Ainda, foram diagnosticados aspectos como, a possibilidade da erva-mate representar um sistema agroecológico, sustentável e viável aos pequenos agricultores; pois ela adapta-se ao sistema de consorcio de culturas agrícolas e pode ser uma fonte de 
renda alternativa para a agricultura familiar. Além de evidenciar as dificuldades de comercialização do produto na região; a falta de apoio técnico, a desorganização dos agricultores e a necessidade de políticas públicas que fomentem a atividade local da erva-mate. Assim, foi demonstrado que um plano de manejo para a cultura da erva-mate só será eficaz quando forem considerados elementos como, possibilidades de comercialização do produto, retorno financeiro para o agricultor/a, política de incentivo governamental, organização dos agricultores, sustentabilidade do agroecosssitema e, principalmente, o respeito à diversidade e o intercâmbio de saberes e práticas. 


\section{ETHNOENTOMOLOGICAL, SOCIOECONOMIC AND ECOLOGICAL ASPECTS RELATED TO THE YERBA MATE (Ilex paraguariensis) CULTURE IN THE MUNICIPAL DISTRICT OF SALTO DA LONTRA, PARANÁ, BRAZIL}

Author: RAQUEL PASINATO

Adviser: Prof. Dr. VALTER ARTHUR

\section{SUMMARY}

This study was carried out with the objective of accomplishing an ethnoentomological study with the yerba mate producers of the Municipal district of Salto do Lontra, Southwest area of Paraná, aiming at diagnosing elements for a management project that leads to a contribution towards a solution to the plant health/crop protection, socioeconomic and environmental problems faced by the farmers of the municipal district. Qualitative and quantitative research parameters, such as interviews and collections of insects, have been used with the intention of finding indicators of the answers to the problem of the yerba mate culture decadence in Salto do Lontra. This study wanted to value and to understand the ethnoknowledge of the yerba mate producer, regarding the insects observed in this culture and the cognitions that they have about these insects. It has been observed that the farmers identify and know the insects, classifying them as beneficial or malicious, only when they cause damages to their plantations. Furthermore, it has been diagnosed aspects such as the possibility of the yerba mate to represent an agroecological system, sustainable and viable to the small 
farmers because it adapts well to the system of agricultural cultures association, and it can be a source of alternative income for the agricultural family. This study has also evidenced the difficulties of the product commercialization in the area, the lack of technical support, the farmers' disorganization, and the need of public politics that foment the local activity of the mate. It has demonstrated that a management project for the culture of the yerba mate will only be effective when it is considered elements such as possibilities of commercialization of the product, financial return for the producer, politics of government incentives, farmers' organization, sustainability of the agroecosystem and, mainly, the respect to the diversity and the exchange of knowledge and practices. 


\section{INTRODUÇÃO}

Este trabalho representa o início de uma descoberta. A descoberta construída ao longo dos acontecimentos, durante uma pós-graduação.A ciência da academia nos apresenta alguns caminhos como receitas a serem seguidas, mas, quando cansamos de fazer repetições e a inquietude nos angustia, precisamos mudar de rumo, para um dia nos encontrarmos.

Na tentativa de encontrar o caminho, descobriu-se entre leituras, discussões, disciplinas e atividades do mestrado, autores como Santos, Diegues, Marques, Morin e Posey, dentre outros, os quais permitem acreditar-se que há outras possibilidades de transformação da sociedade, através de novos paradigmas de ciência, outras visões de mundo, outras racionalidades que não as que separam as ciências naturais das ciências sociais e adotam somente o positivismo lógico como a verdade dos fatos, além de fazer distinção hierárquica entre conhecimento científico e conhecimento do senso comum.

Dentro os direcionamentos apresentados, a opção pela busca de uma abordagem de interação entre a biologia e a antropologia levaram este trabalho ao campo da etnobiologia. Uma ciência considerada nova pelos especialistas da área e que apresenta possibilidades de estudar o relacionamento entre as sociedades humanas e a natureza. $\mathrm{Na}$ etnobiologia o conhecimento do indivíduo estudado sobre seu ambiente e os elementos que o compõe, um agroecossistema em sua complexidade por exemplo, é considerado muito importante e contribui na resolução dos problemas locais das comunidades estudadas.

Nesse sentido, o trabalho foi realizado objetivando estudar as relações dos/as agricultores/as do Município de Salto do Lontra, PR, produtores de erva-mate (Ilex paraguariensis), com os insetos pragas e/ou inimigos naturais deste agroecossistema. Ao 
mesmo tempo procurou-se considerar outros aspectos que circundam a atividade, como os socioeconômicos e ecológicos.

A erva-mate pode representar um auxílio no equilíbrio dos ecossistemas locais, pois aceita o sistema de consorciamento com outras plantas, devido o seu caráter nativo presente na mata Atlântica e, assim, preserva a entomofauna local, auxiliando no equilíbrio do agroecossistema. Por estes motivos fazem-se necessários estudos descritivos das situações problemáticas para que, a partir deles, se possam elaborar projetos de manejo adequados à manutenção da cultura e, conseqüentemente, à melhoria da qualidade de vida dos agricultores que desenvolvem esta atividade.

A erva-mate é de ocorrência natural nos Estados do Sul do Brasil (Paraná, Santa Catarina e Rio Grande do Sul) e também, em menor quantidade, no Mato Grosso do Sul. No Estado do Paraná, particularmente, ela aparece significativamente na produção agrícola do estado. É considerada uma atividade importante para pequenos produtores, uma vez que utiliza a mão de obra familiar no campo, além de gerar mais de 700 mil empregos na indústria.

A cultura é antiga na região Sul, tendo sido descoberta pelos índios e utilizada posteriormente pelos colonizadores, representando uma expressão cultural forte na região Além de serem usadas no chimarrão ou no preparo do chá, as folhas da ervamate, constituem-se em matéria prima para corante natural, antioxidante, cosméticos e medicamentos. A erva-mate é também considerada uma bebida, tônica, estimulante e diurética.

Considerando a importância econômica e ambiental da cultura da erva-mate para pequenos e médios produtores rurais, realizou-se o estudo de alguns problemas que vêm afetando sua atividade. Para tanto, buscou-se saber do agricultor o seu conhecimento sobre os aspectos que envolvem esta cultura.

Assim, o trabalho organiza-se da seguinte forma:

No capítulo 1 tem-se a Introdução, bem como o Problema, as Hipóteses e os objetivos que conduziram a pesquisa.

No capítulo 2 tem-se a Revisão de Literatura, em que se apresenta a cultura da erva-mate e os fatores a ela associados, bem como a presença do agricultor familiar no 
Paraná. Também há uma reflexão sobre a agricultura moderna e as propostas da agroecologia, bem como as contribuições de alguns autores em trabalhos de etnobiologia e a relevância destas pesquisas na valorização do etnoconhecimento.

O capítulo 3 (Metodologia) apresenta a perspectiva de ciência na qual se acredita e que norteia a pesquisa, bem como o método e os procedimentos adotados no estudo.

No capítulo 4 têm-se resultados e discussão, com a apresentação das interpretações do discurso dos agricultores sobre os problemas, os aspectos etnoentomológicos, ecológicos e socioeconômicos da cultura da erva-mate.

No capítulo 5 têm-se as considerações finais, em que se colocam alguns elementos encontrados ao longo do trabalho buscando a compreensão do todo.

\subsection{Problema}

O município tem uma economia baseada essencialmente na agricultura praticada na maior parte por pequenos agricultores. A cultura da erva-mate inicio-se em Salto do Lontra a cerca de dez anos, representando uma fonte de renda alternativa para os agricultores familiares e conseqüentemente contribuindo para melhorar as condições de vida da população local. Atualmente, a cultura da erva-mate está em declínio na região sudoeste do Paraná, representando uma perda valiosa de renda de sua população regional sem que se tenha esgotado a plenitude de suas reais e diversificadas potencialidades. Os agricultores estão abandonando os ervais e optando por outras culturas agrícolas, as quais nem sempre são mais adequadas ecologicamente. Assim, perante a gravidade dos problemas ambientais que perpassam a sociedade contemporânea, práticas agrícolas alternativas e menos agressivas que as da agricultura convencional, precisam ser incentivadas e preservadas para que seja possível constituir agroecosssitemas ambientalmente sustentáveis. 


\subsection{Hipóteses}

- Os problemas com as pragas estão levando os agricultores a abandonar a cultura da erva-mate na região.

- Os agricultores conhecem os insetos associados às culturas que plantam e têm uma relação negativa com os mesmos, vendo-os como pragas que devem ser eliminadas.

- O agroecossistema da erva-mate pode ser ecologicamente equilibrado e sustentável se o conhecimento etno do agricultor for levado em consideração em um plano de manejo.

- A biodiversidade da entomofauna do agroecossistema da erva-mate na região é abundante, mesmo em ervais plantados.

\subsection{Objetivos}

\subsubsection{Objetivo Geral}

Realizar um estudo etnoentomológico com os produtores de erva-mate do Município de Salto do Lontra, PR visando diagnosticar elementos para um plano de manejo que contribua para a solução de problemas fitossanitários, socioeconômicos e ambientais enfrentados pelos agricultores de Salto do Lontra.

\subsubsection{Objetivos Específicos}

- Identificar as percepções dos agricultores sobre o problema e o conhecimento deles sobre os insetos associados à cultura da erva-mate;

- Comparar o etnoconhecimento do agricultor em relação aos insetos pragas e inimigos naturais da cultura da erva-mate com o conhecimento encontrado na literatura especializada e coletas realizadas; 
- Identificar quais problemas afetam o setor ervateiro, relacionado a pequenos e médios agricultores da região sudoeste do Paraná, especificamente no município de Salto do Lontra;

- Demonstrar a viabilidade ecológica da cultura da erva-mate como alternativa de restabelecimento de ecossistemas simplificados pelas práticas agrícolas atuais. 


\section{REVISÃO DE LITERATURA}

\subsection{A cultura da erva-mate}

A história econômica do mate remonta ao período da colonização européia, mais especificamente quando o General Irala desbravava o Paraguai chegando em Guaíra, por volta de 1554. Ao chegar na região, percebeu que os índios de Guaíra eram mais fortes que os guaranis e o mais curioso era que eles faziam uso generalizado da bebida feita de folhas fragmentadas, ou trituradas, tomada em uma cuia por meio de um canudo de taquara (Linhares, 1969).

Após os índios, os soldados do general Irala provavelmente foram os primeiros não índios a experimentar o mate. Este foi sendo difundido aos poucos nos lares espanhóis, iniciando-se um conjunto de relações econômicas da maior importância (Linhares, 1969).

Assim, o Paraguai se movimentou em torno do produto, colocando os índios à frente do desbravamento da erva nas regiões de Maracaju, Ivaí e Alto Uruguai com empório de vendas em Assunção. As encomendas eram distribuídas aos conquistadores e aventureiros e supriam as regiões litorâneas até as mais meridionais como do Rio da Prata e daí para os mercados da Argentina, Chile, Bolívia e Peru (Linhares, 1969).

Segundo Costa (1995) e Linhares (1969), houve tentativas de proibir o seu uso, sob a alegação de supostas propriedades afrodisíacas, levando os jesuítas a denominá-la, no início da colonização, de “erva do diabo”. Posteriormente, o hábito se generalizou desde o Peru ao Rio da Prata, penetrando nos lares dos colonizadores europeus, como bebida de todas as horas e de todos os lugares. 
Os jesuítas, que no início a combateram, se tornariam depois os seus melhores difusores, procurando melhorar-lhe o preparo e até promovendo o seu cultivo. O vício, juntamente com as possibilidades lucrativas do negócio, superaram o suposto lado negativo do pecado e da excomunhão. Muitos espanhóis enriqueceram, mas milhares de índios foram excluídos e escravizados neste processo (Linhares, 1969 e Costa, 1995).

Mesmo com ervais nativos abundantes, os jesuítas não tardaram a fazer plantações do mate, estudando seu sistema vegetativo e aperfeiçoando cada vez mais o cultivo da planta. Afinal, o cultivo das árvores diminuía as despesas com transporte e mantinha os trabalhadores às vistas dos padres. A estes coube a prerrogativa de difundir o uso da infusão em forma de chá, conhecido na época como "chá dos Jesuítas" (Linhares, 1969).

A erva cultivada e fabricada pelos jesuítas era denominada "caamíni” e era mais apreciada e tinha mais valor no mercado que a “erva-de-palos”, fabricada pelos espanhóis. O processo era guardado a sete chaves pelos jesuítas e a Companhia de Jesus explorou a exportação do mate,seu cultivo, a sua extração, por mais de um século e meio, desde 1610 até 1768, quando ocorreu a saída forçada da Companhia de Jesus das terras da América (Linhares, 1969)

Em 1638 os bandeirantes invadiram as Missões do Guaíra, descobriram também a erva-mate e a levaram para São Vicente. Os tropeiros que vinham de Minas Gerais comprar mulas nos Campos Gerais também voltavam com grandes carregamentos de erva e a bebida foi se difundindo cada vez mais. Em 1813 as exportações paraguaias foram proibidas pelo ditador Dr. Francia e o Brasil tornou-se o único produtor e exportador, transformando a erva-mate numa das maiores riquezas nacionais e tornando Curitiba um grande centro de exportação (Anuário Brasileiro da Erva-Mate, 1999).

Segundo Linhares (1969), em meio a todo este complexo mercado do mate e à saga exploratória da colonização européia, alguns naturalistas descreveram em suas excursões botânicas na América a cultura do mate, como por exemplo, o francês Aimé Bonpland.

Quando este naturalista esteve no Brasil, na Província do Rio Grande do Sul, pensou muito na necessidade de cultivar ervais e de criar novos ervais, ao mesmo tempo 
que criticava o método de trabalho empregado por implicar na destruição em massa de imensas florestas de erva-mate. Na época Bonpland já mencionava o plantio da erva associado a outros vegetais. No entanto, os conselhos do naturalista francês foram desprezados pelo Brasil, mas muito bem aproveitadas pelos argentinos um século depois. (Linhares, 1969).

Saint Hilaire foi o primeiro cientista a classificar e publicar uma nomenclatura para a erva-mate, baseado em exemplares coletados na região de Curitiba, durante suas viagens ao sul do Brasil, em 1820. Ele enviou amostras da planta para o Museu de História Natural de Paris, onde ocorreu uma mistura com outras amostras, havendo troca de etiquetas de identificação e assim, a erva brasileira foi considerada idêntica à do Paraguai e ganhou o nome de Ilex paraguariensis (Anuário Brasileiro da Erva-mate, 1999; Costa, 1995; Linhares, 1969).

No território de Missiones, Argentina, iniciou-se os primeiros cultivos por possuir aquela terra condições climáticas e tipo de solo adequado ao plantio, por volta de 1911 inúmeros ervais cultivados, amparados pela ajuda oficial, se espalharam em várias localidades do território. A produção cresceu e o país passou a armazenar mais do que as necessidades de consumo (Linhares, 1969). No Brasil, a descoberta comercial do mate deu-se tardiamente com a investigação da flora no planalto curitibano, onde a planta era consumida pelos índios caigangues e entre os brancos da região Sul do Brasil, os quais a chamaram de "congonha”. No ínicio do século XVIII o uso da bebida tinha se difundido no interior paulistano, hoje paranaense com o despertar de um interesse do governo português pela comercialização da bebida, talvez em estímulo às Vilas do Sul, que se encontravam em decadência (Linhares, 1969).

No entanto, a grande oportunidade do Brasil apareceu um século depois, com o abandono dos ervais jesuíticos e o comércio paraguaio em profundo colapso. Restava aos produtores brasileiros agora, adquirirem as técnicas de preparo elaboradas pelos jesuítas, porque os mercados já faziam tais exigências. Com a abertura de estradas e as circunstâncias políticas que impediam a comunicação do Paraguai com Buenos Aires, os interessados precisavam vir a Paranaguá para adquirir o produto (Linhares, 1969). 
Em 1835 a região de Morretes e Paranaguá apresentava cerca de 20 fábricas de Soque e toda a produção era absorvida pelos mercados platinos. O sucesso do mate proporcionou um bem comum a pequenos empresários, a pequenos comerciantes intermediários de matéria-prima e aos que partipavam diretamente nos trabalhos de beneficiamento e produção. Mas, a cobiça pelo lucro imediato, levou muitos a fraudarem e falsificarem o produto, causando prejuízos enormes (Linhares, 1969).

No Rio Grande do Sul, em meados do século XIX, a cultura do mate se expandia e o estado precisava importar mate do Paraná e Santa Catarina para suprir o consumo interno. Com a crise da pecuária gaúcha e a Revolução Farroupilha, a erva-mate passou a ser esteio econômico da revolução, sendo representada na bandeira, nos lenços e distintivos dos republicanos (Linhares, 1969).

Por volta de 1849 as exportações paranaenses cresciam a cada ano e a região de Morretes vivia uma de suas fases mais florescentes. Porém, a maior dificuldade encontrada na época era com o transporte da matéria-prima para os portos e a comunicação dos povos de serra acima com o litoral, visto que as estradas eram rudimentares e precárias. Com isso, o governo da época tomara providências para melhorá-las, afinal o mercado do mate era muito lucrativo, sendo que no governo de Zacarias de Góis os soques existentes no Paraná já chegavam a noventa (Linhares, 1969).

A região do Alto Paraná foi inicialmente o centro abastecedor dos mercados rioplatenses, não só pela existência de apreciáveis ervais nativos, mas pela facilidade do escoamento através dos rios Paraná, Paraguai e da Prata, quando as comunicações por terra eram difíceis (Costa, 1995).

O mesmo governo alertava para um problema que mais tarde seria crucial: o perigo da monocultura e a superprodução que levou a superabundância de oferta nos mercados, conseqüentemente cada vez mais exigentes na qualidade do produto. Assim, por volta de 1859, o mate paranaense enfrentou uma crise proverbial em sua trajetória (Linhares, 1969).

Um pouco mais tarde, em Santa Catarina iniciou-se a exploração em Lajes com a instalação dos primeiros engenhos, sendo a produção deste Estado, sincronizada com a 
economia paranaense. O Estado foi sendo ocupado pelos imigrantes, principalmente alemães, os quais se adaptaram logo ao uso do mate, bem como à prática de seu comércio, que enriqueceu muitos deles (Linhares, 1969).

Após a Guerra do Paraguai o Brasil ganhou os mercados e o mate era para o Paraná o mesmo que o café para São Paulo ou a borracha para os estados amazônicos. Em 1875, o Paraná com uma população de 127.000 habitantes, consumia, diariamente, cerca de 750 arrobas de erva-mate, o que equivalia a mais de 4 milhões de quilos de consumo anual (Linhares, 1969).

\subsubsection{Os ciclos do mate}

Sintetizando, o cenário da erva-mate pode distinguir-se em três ciclos:

No primeiro o mate se beneficiava à custa do trabalho indígena, sendo mais destinado ao consumo doméstico com produção reduzida e, beneficiamento primitivo e rudimentar, longe dos padrões exigidos pelos mercados platinos. Neste ciclo, até 1820, o mate paranaense ainda não se tornara produto de exportação (Linhares, 1969)

O segundo ciclo começa com a instalação do primeiro engenho em Paranaguá com conhecimentos e experiências trazidas do Paraguai por seu idealizador, podendo ser denominado de um ciclo industrial pelo emprego da força hidráulica a vapor e pelas melhorias no acondicionamento do produto. Neste ciclo, a erva paranaense já concorria com a do Paraguai e com a da Zona missioneira do Rio Grande (Linhares, 1969).

O terceiro ciclo foi entre 1875 e 1880, com o deslocamento dos engenhos para o planalto curitibano. Novas técnicas de industrialização permitiram à indústria paranaense suplantar as do Rio Grande do Sul e do Paraguai, tornando o mate paranaense preferido nos mercados uruguaio, argentino e chileno. Esta foi, sem dúvida a fase de excelência do mate paranaense, quando ele fora base econômica do estado, fator de povoamento, progresso e civilização (Linhares, 1969).

No decorrer do último século muitas transformações ocorreram em torno do mercado da erva-mate. Em 1910, com a decisão da questão dos limites de Missões, o presidente dos Estados Unidos julgou o caso em favor da Argentina e lá se foi uma boa 
parte de nossa região ervateira, a única até hoje daquele país, que se constituiu no maior produtor e exportador mundial de erva-mate (Anuário Brasileiro da Erva-Mate, 1999).

Em 1966, o Brasil teve suas exportações de erva-mate completamente sustadas para o mercado argentino perante alegações de que este era auto-suficiente e produzia o necessário para consumo interno e exportação, inclusive para os mercados do Uruguai e Chile que eram do Brasil até então ( Linhares, 1969).

Atualmente, o Brasil é o segundo maior produtor mundial de erva-mate, só perdendo para a Argentina, sendo o estado do Paraná o maior produtor. A indústria nacional produz anualmente cerca de 270 mil toneladas de erva-mate e o maior importador é o Uruguai, que absorve cerca de 81\% da produção (Anuário Brasileiro da Erva-Mate, 1999).

Tradicionalmente, a erva-mate (Ilex paraguariensis) compõe um dos sistemas agroflorestais mais antigos e característicos da região Sul do Brasil, assumindo importância ambiental e socioeconômica significativa, foi por um longo tempo um dos primeiros produtos das exportações brasileiras. (Penteado et al., 2000).

A partir da década de 60 com a implantação de novas áreas de cultivo, muitos ervais nativos desapareceram. A escassez de matéria-prima para a produção de chimarrão e chás fez com que a erva-mate passasse a ser cultivada em monocultura, alterando severamente as características do seu ecossistema original (Alves et al., 2000).

A erva-mate, através do tempo, passou de um sistema natural (florestal) para um sistema artificial (monocultura), o qual, segundo Fernandez Diaz (1997) pode ser chamado de agroecossistema, no qual existe pouca diversidade de espécies com um elevado número de indivíduos, tornando este sistema suscetível ecologicamente.

Nessa nova condição, sob constante desequilíbrio, muitos problemas de ordem fitossanitária começaram a surgir na cultura.

Também, fatores tecnológicos, econômicos de mercado e o próprio manejo da cultura, têm alterado o quadro de prosperidade da atividade ervateira no estado do Paraná e demais regiões produtoras, pois o setor passa por um momento de transição preocupante (Rucker et al., 2003). Tais preocupações estão relacionadas aos problemas enfrentados no setor tecnológico, tais como colheita da safrinha no verão, período em 
que a planta está em pleno desenvolvimento, falta de pesquisas técnicas que forneçam dados de base para decisões de produtores e industriais, avaliação dos custos dos diferentes sistemas produtivos, capacitação da mão de obra e exploração sustentável da cultura; fatores econômicos e de legislação do produto também estão no rol das preocupações do setor ervateiro.

\subsubsection{Características fenológicas da erva-mate}

A área de distribuição natural da erva-mate abrange aproximadamente $540.000 \mathrm{~km}^{2}$, compreendendo territórios do Brasil, da Argentina e do Paraguai, situados entre as latitudes de $21^{\circ} \mathrm{S}$ e $30^{\circ} \mathrm{S}$ e longitudes de $48^{\circ} 30^{\prime} \mathrm{W}$ e $56^{\circ} 10^{\prime} \mathrm{W}$, com altitudes variáveis entre 500 e 1000m (Grigoletti Jr. et al., 1997).

Só no Brasil, os ervais nativos se estendem por $450.000 \mathrm{~km}^{2}$, abrangendo a região centro-norte do Rio Grande do Sul, quase todo o estado de Santa Catarina, centro-seu e sudoeste do Paraná, sul do Mato Grosso do Sul, e reduzidas áreas em Minas Gerais e São Paulo (Costa, 1995 e Grigoletti Júnior et al., 1997), podendo ser observado na Figura 1.

A erva-mate é um arbusto característico de plantas de sub-bosque, pertencente a um agrupamento vegetal típico do sul do Brasil, conhecido como "formação de araucária”, sendo características de regiões com altitude acima de 400 metros (Costa, 1995 e Andrade et al., 1999).

Pertencente à família Aquifoliaceae o gênero Ilex possui mais de 550 espécies, das quais 60 ocorrem no Brasil, mas apenas cinco delas se prestam ao beneficiamento para consumo (Anuário Brasileiro da Erva-Mate, 1999). As erveiras podem chegar aos 15 metros de altura (Anuário Brasileiro da Erva-Mate, 1999), sendo que a filotaxia das folhas é alterna. Estas são ovais e medem de oito a dez centímetros de comprimento por quatro a cinco centímetros de largura (Costa, 1995).

Pelo grande número de espécies, a erva-mate pode se apresentar tanto com o talo branco como roxo, bem como com as folhas de diversos formatos, como lanceoladas ou denticuladas (Anuário Brasileiro da Erva-Mate, 1999). 


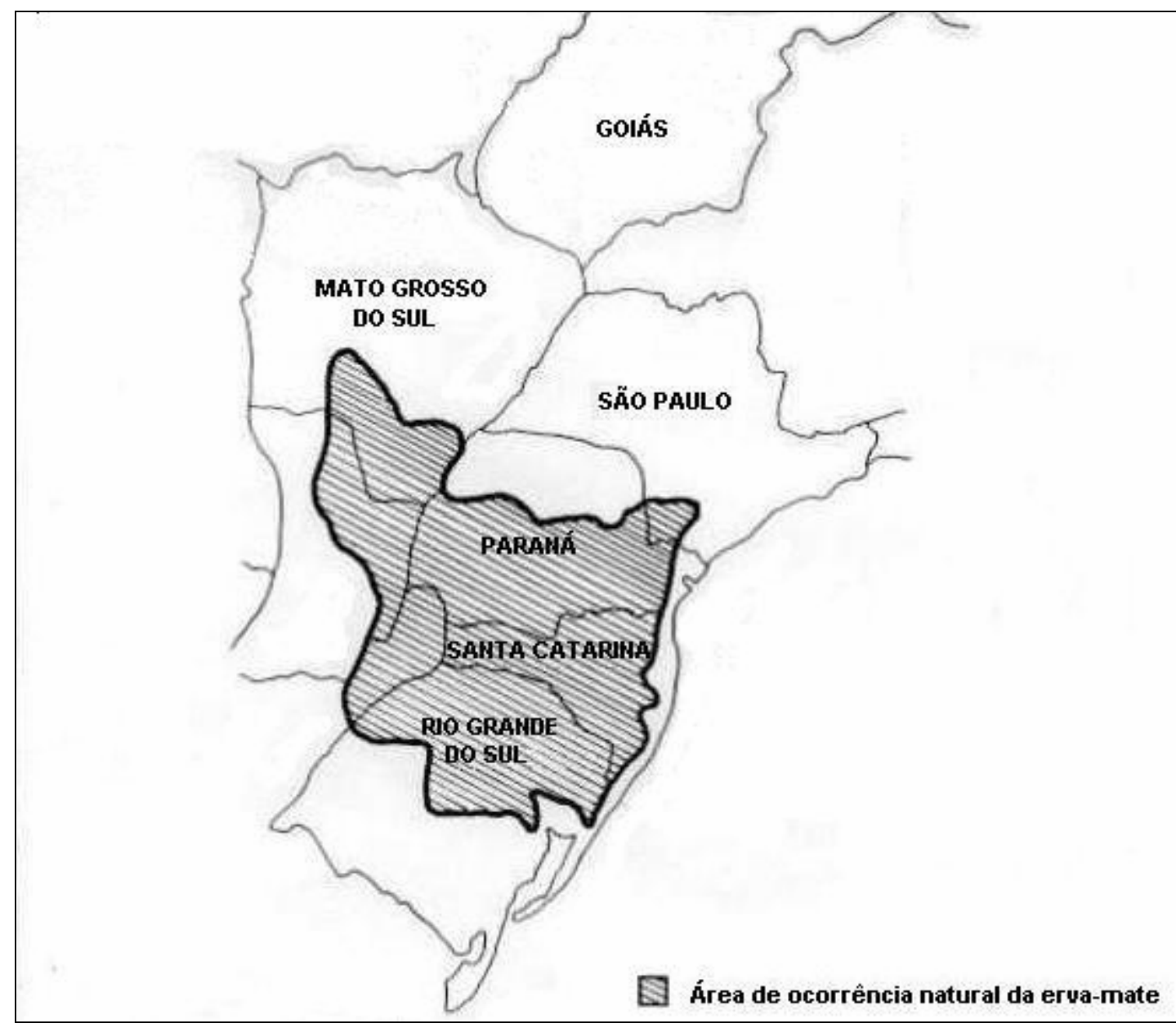

Adaptado de Mazuchowski, Jorge Z. Manual da erva-mate. Curitiba. Emater-PR, 1988.

Figura 1- Mapa da localização geográfica da erva-mate no Brasil

As plantas são dióicas, sendo que cada árvore produz somente flores masculinas ou somente flores femininas e a floração ocorre de setembro a dezembro, predominando em outubro. O amadurecimento dos frutos se dá de janeiro a março (Anuário Brasileiro da Erva-Mate, 1999).

As melhores condições de desenvolvimento, bem como de longevidade, sanidade e produtividade da erva-mate estão intimamente ligadas à fertilidade do solo e à sua exploração racional (Costa, 1995). Ocorrem naturalmente em solos profundos; bem drenados; ácidos ou ligeiramente ácidos; argilosos, argilo-silicosos ou sílico-argilosos, ou parcialmente arenosos (Costa, 1995 e Anuário Brasileiro da Erva-Mate, 1999). A 
umidade e a profundidade são fatores importantes, não devendo haver excesso de água. Embora originalmente floresça como sub-bosque, a erva mate resiste bem a céu aberto, quer em formações nativas, quer em formações cultivadas, e podendo também ser consorciada com diversas culturas anuais, principalmente com milho e feijão (Costa, 1995 e Anuário Brasileiro da Erva-Mate, 1999).

As erveiras, como regra, não temem as geadas, a não ser as recém-podadas e mal enfolhadas; a brotação não suporta, porém fortes geadas (Costa, 1995).

\subsubsection{Pragas da erva-mate; inimigos naturais e equilíbrio ecológico do agroecossistema}

Na cultura da erva-mate, alguns insetos têm sido observados causando danos significativos. Segundo Fernandez Dias (1997); Penteado et al. (2000) e Gallo et al. (2002) foi constatado nesta cultura o ataque das brocas Hedypathes betulinus (broca-daerva-mate ou corintiano) e Isomerida picticalis (broca-dos-ponteiros-da-erva-mate), do psilídeo, Gyropsylla spegazziniana (ampola-da-erva-mate), das lagartas desfolhadoras Thelosia camina e Hylesia sp., Perigona lusca (lagarta-rabuda), da cochonilha Ceroplastis grandis (cochonilha de-cera) e dos ácaros Dichopelmus notus, Polyphagotarsonemus latus e Oligonychus yothersi.

Para algumas das pragas acima citadas, encontramos na literatura especializada inimigos naturais já estudados. Assim, Hedypathes betulinus (broca-da-erva-mate ou corintiano) possui os seguintes inimigos naturais:

Alcaeorrhynchus grandis (Hemiptera: Pentatomidae), Apiomerus sp. (Hemiptera: Reduviidae), Arilus carinatus (Hemiptera: Reduviidae), Brontocerus tabidus (Hemiptera: Pentatomidae), Thynacantha marginata (Hemiptera: Pentatomidae), Eurytoma sp. (Hymenoptera: Eurytomidae), Pheidole sp. (Hymenoptera: Formicidae), Solenopsis sp. (Hymenoptera: Formicidae), segundo Fernandez Diaz (1997), Soares (1998) e Penteado et al. (2000). Podisus sp. (Hemiptera: Pentatomidae), segundo Fernandez Diaz (1997). Labena sp. (Hymenoptera: Ichneumonidae), Guira guira (Anubranco) (Cuculiformes: Cuculidae), Zonotrichia capensis (Tico-tico) (Passeriformes: 
Fringillidae), segundo Soares (1998). Numida meleagris (Galinha-de-Angola) (Galliformes: Numididae) segundo Anuário Brasileiro da Erva-Mate (1999).

Beauveria bassiana, Metarhizium anisopliae, segundo Soares (1998) e Penteado et al (2000).

Para Gyropsylla spegazziniana (ampola-da-erva-mate) encontramos:

Cycloneda sp. (Coleoptera: Coccinellidae), Exochomus jourdani (Coleoptera: Coccinellidae), Hyperaspis munhi (Coleoptera: Coccinellidae), Olla abdominalis (Coleoptera: Coccinellidae), Scymnus argentinicus (Coleoptera: Coccinellidae), Scymnus sp. (Coleoptera: Coccinellidae), Azya luteipes (Coleoptera: Coccinellidae), Largus rufipennis (Hemiptera: Largidae), Podisus connexivus (Hemiptera:Pentatomidae), Crematogaster sp. (Hymenoptera: Formicidae), Procryptocerus sp. (Hymenoptera: Formicidae), Pseudomyrma gracilis (Hymenoptera: Formicidae), Chrysoperla externa (Neuroptera: Chrysopidae), Chrysopodes ogloblini (Neuroptera: Chrysopidae), Ocyptamus erebus (Diptera: Syrphidae), Pseudodorus clavatus (Diptera: Syrphidae), Toxomerus sp. (Diptera: Syrphidae), segundo Fernandez Diaz (1997). Corinus coeruleus (Coleoptera: Coccinellidae), Cycloneda sanguinea (Coleoptera: Coccinellidae), segundo Fernandez Diaz (1997) e Chiaradia et al. (2000). Ocyptamus amplus (Diptera: Syrphidae) Ocyptamus anthiphates (Diptera: Syrphidae), Ocyptamus caldus (Diptera: Syrphidae), Ocyptamus norina (Diptera: Syrphidae) segundo Fernandez Diaz (1997) e Fernandez Diaz et al (2000) Halictophagus sp. (Strepsiptera: Halictophagidae), segundo Fernandez Diaz (1997) e Penteado et al (2000).

Para Perigona lusca (lagarta-rabuda) tem-se:

Bacillus thuringiensis segundo Fernandez Diaz (1997), Baculovírus perigonia conforme Fernandez Diaz (1997) e Alves et al. (2001), Baculovírus, segundo Alves et al. (2001).

Estes são exemplos dos problemas fitossanitários da cultura da erva-mate, que acarretam queda na produtividade e aumento nos custos de produção e de inimigos naturais que podem ajudar a diminuir estes problemas. Segundo Penteado et al. (2000), medidas de controle destas pragas fazem-se necessárias, frente aos aspectos econômicos de mercado e mesmo a sobrevivência da população rural que vive desta atividade. 
Conforme Penteado (1995), em função do aumento da área de plantio de ervamate em povoamentos puros e ervais nativos em sistema de monocultura, tem-se observado um aumento populacional de várias espécies de insetos sobre estas plantas. Em monocultura, o equilíbrio biológico é quebrado porque ocorre a eliminação drástica de espécies de plantas que serviam de abrigo para inimigos naturais de espécies fitófagas. Além disso, a disponibilidade de alimento às espécies fitófagas aumenta e algumas que até então ocorriam em baixos níveis populacionais, tornam-se pragas, provocando vários danos à cultura. Ainda, o uso de agrotóxicos utilizados para combatêlas, apesar de reduzir a população de pragas, muitas vezes elimina o seu inimigo natural.

Através das práticas agrícolas atuais e das suas diversas atividades em relação aos ecossistemas naturais, o ser humano vem modificando o meio ambiente. Assim, ecossistemas são obrigados a suprir estas modificações, transformando-se em agroecossistemas que incluem o campo agrícola de cultivos diversos, áreas ocupadas com vegetação natural e todos os componentes bióticos e abióticos característicos de cada local (Speight et al., 1999). Os componentes principais são os cultivos em sua relação com solo e biota, ervas associadas, pragas com seus fatores de mortalidade natural que incluem entomopatógenos e inimigos naturais, todos condicionados pelo clima e pelas atividades agrícolas do homem (Trujillo, 1995).

É importante notar que os agroecossistemas não são estáveis, estão em constante evolução e, no âmbito das atividades de cultivo do homem, as pragas rompem seu equilíbrio natural, se antecipando aos predadores e parasitos (Speight et al., 1999).

Frente à problemática apresentada, alternativas de controle são mais que necessárias, uma vez que grandes áreas já foram infestadas. Até o momento não existem acaricidas e inseticidas registrados para o uso na cultura da erva-mate e a utilização do controle químico tem agravante de que a matéria prima para os produtos são as folhas que serão utilizadas pelo consumidor como infusão, podendo acarretar riscos de intoxicação aos consumidores (Penteado et al., 2000).

Diante de tais problemas, a necessidade de estudos faz-se necessária. Estudos de comportamento, nível de dano e biologia das pragas e também de igual importância o estudo da biologia dos prováveis inimigos naturais destas pragas, para que se possa 
avaliar posteriormente a capacidade destes inimigos naturais como agentes de controle biológico que possam ser utilizados no manejo integrado (Alves et al., 2000). Mas para tal processo é necessário conhecer, de modo geral, a diversidade da entomofauna da região do erval.

O manejo integrado, definido como seleção, integração e execução de métodos de controle baseados em conseqüências ecológicas, socioecológicas e econômicas, pode viabilizar o controle das pragas. É um sistema adequado para manter a população no nível de danos toleráveis pelo sistema produtivo (Fernandez Dias, 1997 e Soares \& Iede, 1997).

Segundo Wilson \& Huffaker (1976) o controle biológico de pragas, que consiste em controlar as pragas através de seus inimigos naturais, é a técnica mais importante de proteção, é ecologicamente melhor, é em geral de baixo custo, sem efeitos colaterais adversos quando comparado ao controle químico e por isto a importância de estudos desta técnica.

Segundo Hagen (1974), existem cerca de 4000 coccinelídeos descritos, porém conhece-se muito pouco da biologia dos coccinelídeos predadores. O conhecimento da biologia destes organismos poderia proporcionar a criação em massa e a colonização periódica do inimigo natural com a finalidade de corrigir a assincronia com relação à presa. Afinal, os coccinelídeos já têm demonstrado um papel significativo em controle biológico e integrado, e o caso mais famoso de sucesso absoluto foi o da joaninha Rodolia cardinalis, que controlou a cochonilha Icerya purchasi dos citros em cerca de um ano na Califórnia. Foi o primeiro caso de sucesso em controle biológico clássico.

Os coccinelídeos, tanto larvas como adultos, apresentam uma grande diversidade alimentar, sendo predadores de ovos e larvas de primeiro instar de lepidópteros, coleópteros , himenópteros, homópteros e ácaros fitófagos (Hodek, 1973).

Nos citros, segundo Prates (1983) ocorrem diversos coccinelídeos que são predadores de ácaros, pulgões, cochonilhas e moscas brancas. São eles: Cycloneda sanguinea, Olla abdominalis, Coleomegilla maculata, Eriopis conexa, Scymnus spp., Azya luteipes, Pentilia egena, Chilocorus bipustulatus, Stethorus sp. e Delphastus sp. 
Segundo Rott (2000), todas as espécies conhecidas do gênero Stethorus Weise (Coleoptera: Coccinellidae) são predadoras de ácaros e várias espécies foram sugeridas com potencial de agentes de controle biológico do ácaro T. urticae em culturas agrícolas. Assim, McMurtry \& Jhonson (1966), McMurtry et al. (1970) e Rott (2000) concluíram que as espécies do gênero Stethorus são predadoras de ácaros encontrados em alta densidade, e as fêmeas destes predadores necessitam de grandes quantidades de alimento para que ovipositem. Algumas características do Stethorus, indicam seu potencial de biocontrole, pois estes são predadores extremamente vorazes, com adultos de vida longa e são capazes de dispersarem-se efetivamente e hábeis em localizar presas pequenas como os ácaros tetraniquídeos.

Alves et al. (2002) encontraram o coccinelídeo Stethorus histrio Chazeu (Coleoptera:Coccinellidae ) em plantas de erva-mate (Ilex paraguariensis) em Cascavel/PR. O coccinelídeo, quando observado em condições de laboratório exerceu alto índice de predação sobre $O$. yothersi, alimentando-se de ovos, larvas, ninfas e adultos do mesmo.

Os exemplos acima citados apresentam-se como demonstrações de que há alternativas menos drásticas de controle de pragas comparadas àquelas que utilizam-se de produtos químicos e tóxicos, bem como, possibilidades de manejo e manutenção dos agroecossistemas, protegendo e mantendo os inimigos naturais na área considerada, tornando o ambiente mais adequado a eles através de práticas de manejo adequadas. No entanto, segundo os princípios que norteiam o pensamento desta pesquisa, é importante que seja levado em consideração o conhecimento que o produtor rural tem sobre o ambiente em que trabalha, vive e estabelece relações.

Para tal afirmação, baseia-se na perspectiva de valorização de outros saberes ambientais e outras maneiras de conhecimento que é parte da proposta colocada por autores como Gueertz (1997); Morin (2000); Santos (2001); Guzmán (2002) e Leff (2002) que fomentam a expectativa e a concretização de uma nova ciência, baseada também na experiência e no respeito à diversidade. 


\subsubsection{Aspectos culturais, políticos, sociológicos e econômicos da atividade ervateira}

A região Sul do Brasil, assim como outras regiões do país, possui hábitos culturais específicos, como por exemplo, o hábito de tomar chimarrão. Uma bebida quente e estimulante derivada de uma planta já cultivada pelas populações indígenas que habitaram a região antes mesmo da chegada dos europeus, a erva-mate (Ilex paraguariensis) está presente na vida de muitas famílias dos estados do sul (Paraná, Santa Catarina e Rio Grande do Sul) representando, uma herança cultural, histórica e uma fonte de renda importante para muitas delas (Anuário Brasileiro da ervamate,1999).

O produto mais conhecido da erva-mate é o tradicional chimarrão consumido intensamente pelas pessoas que viviam próximas aos afluentes dos rios Paraná, Uruguai e Paraguai, o hábito do chimarrão é ainda hoje cultivando pelos habitantes destas regiões, envolvido por misticismo e significados, sendo a hospitalidade, talvez o mais importante deles (Anuário Brasileiro da Erva-Mate,1999).

De fato, a bebida representa este sentimento de integração, pois assim que chega uma visita na casa, mesmo que seja desconhecida, a primeira coisa que se oferece é o chimarrão, que é posto na roda, anima a conversa e pode transformá-la em amizade, pois matear sozinho é sinônimo de solidão (Anuário Brasileiro da Erva-Mate, 1999).

Segundo Ave - Lallemant (1957, p.136) no Sul do Brasil:

“(...) as mulheres entram em trabalho de parto e passam o tempo de resguardo sorvendo mate e o último olhar do maribundo cai certamente sobre o mate. É o mate a saudação da chegada, o símbolo da hospitalidade, o sinal da reconciliação. Tudo o que em nossa civilização se compreende como amor, amizade, estima e sacrifício, tudo o que é elevado e profundo e bom impulso da alma humana, do coração, está entretecido e entrelaçado com o ato de preparar o mate, servi-lo e tomá-lo em comum. 
A convivência do homem do campo com as plantas, a terra e os animais revelam parte de sua relação com a natureza, ainda que utilitarista. Segundo Brandão (1999), “(...) o lugar natural trabalhado ganha o valor econômico do trabalho”. E é assim que a cultura do mate se difundiu entre as famílias do Sul do Brasil, pois além da expressão dos sentimentos de amizade, o mate se tornou uma fonte de renda importante.

Mesmo passando por várias crises de mercado, a economia ervateira representou o ciclo mais autônomo, prolongado e estável da história do Paraná. A indústria do mate, de 1873 a 1890, absorveu todas as atividades paranaenses, monopolizando capital e trabalho, tornando o mate o principal produto de exportação da província do estado (Costa, 1995 e Andrade et al., 1999).

Diferente do ciclo do café e da madeira, os quais se caracterizam como atividade errante, a atividade ervateira não teve esta característica. Está fixada dentro de sua região ecológica tradicional e o corte da planta não implica na destruição da árvore; é uma poda que a refaz e fortalece. A cultura não esteve sob o controle político de outros estados (Costa, 1995).

Segundo Furtado (1971), a expansão econômica da cultura do mate trouxe benefícios à economia de subsistência constituída de populações transplantadas da Europa. Sendo assim, os colonos do interior puderam dividir seu tempo entre agricultura de subsistência e a extração das folhas da erva-mate, aumentando substancialmente sua renda.

Assim, a erva-mate contribuiu para a fixação dos imigrantes italianos, poloneses e ucranianos no final do século passado, assegurando a sobrevivência de muitas destas famílias, pois o imigrante se fez erveiro, afeiçoado ao uso diário do chimarrão, do churrasco e dos costumes campestres (Costa, 1995).

A atividade agrícola da erva-mate é de grande importância econômica, sociocultural e ambiental, sendo, a principal atividade econômica de muitos municípios gerando cerca de 700 mil empregos diretos e indiretos e movimentando cerca de 180 milhões de recursos por ano. A atividade ervateira está presente em cerca de 180 mil propriedades rurais, sendo na maior parte pequenas e médias empregando a mão-de-obra familiar no campo (Anuário brasileiro da erva-mate, 1999 e Andrade et al., 1999) 
Em áreas cultivadas, o maior rendimento na produção vai depender da localização do erval, dos processos agrícolas adotados, fertilidade do solo e exploração racional. Segundo Mazuchowski (1989), a planta é capaz de viver em estado selvagem algumas dezenas de anos, permitindo colheitas remuneradas, desde que sua exploração seja realizada com cuidado, pois existem indicações de que a produção aumenta gradativamente até os 30 anos de idade.

A região sul do Brasil responde por cerca de 97\% da produção nacional, ficando o restante para o Mato Grosso do Sul. No sul, a maior parte da matéria-prima provém de ervais nativos, em especial no Paraná onde há maior concentração.

O consumo do produto está atrelado à tradição de se tomar chimarrão, chá ou derivado e os estados do Paraná e Rio Grande do Sul são os tradicionais consumidores de chimarrão, cerca de $80 \%$ do consumo é na forma desta bebida, já a região do Mato Grosso do Sul demanda e aprecia mais o chá mate e o tererê (Andrade et al., 1999).

Até 1980, todas as exportações brasileiras de erva-mate destinavam-se ao Uruguai. Porém, a partir de 1988, as exportações passaram a atingir os mercados da Síria, Alemanha, Japão e Estados Unidos. A procura pela erva-mate deu-se principalmente pelo fato de servir como alimento e ser medicinal e, ainda, porque as colônias brasileiras instaladas nestes países possuem o hábito de tomar chimarrão (Andrade et al., 1999).

A partir de 1989 ocorreu uma queda na produção nacional de erva-mate, o que pode ser explicado pela exaustão ocorrida pela exploração contínua e o avanço das áreas de lavouras sobre as matas nativas. Porém, paralelamente a demanda interna e externa aumentou, o que incentivou os plantios comerciais da erva-mate (Andrade et al., 1999).

Quanto às importações brasileiras de erva-mate, segundo Rucker (1996), a economia ervateira tem se mantido ao longo dos anos entre relações comerciais de Brasil e Argentina. O comportamento da demanda pela matéria prima erva-mate, determinou e determina a alternância das importações/exportações entre estes dois países produtores e parceiros comerciais.

\footnotetext{
${ }^{1}$ Diferente do chimarrão que é uma bebida quente, o tererê é uma bebida servida fria, feita com as folhas de erva-mate, menos trituradas, de forma mais grosseira.
} 


\subsubsection{Organização dos agricultores familiares em relação à cultura da erva-mate no Sul do Brasil: possibilidades emergentes}

Tradicionalmente, a cadeia produtiva da erva-mate não é caracterizada por iniciativas associativas. Entretanto, nos últimos tempos tem-se verificado a organização de produtores, especialmente para beneficiar a produção que não conseguem vender.

O setor produtivo da erva-mate é desagregado por várias razões etno-culturais e sociais, existindo poucas atividades associativas em nível de cadeia produtiva. No estado do Paraná apenas três cooperativas estão envolvidas com o setor ervateiro (Rucker, 1997).

Em outros estados, como Santa Catarina, apenas uma cooperativa, em Canoinhas, se dedica a esta área, já no Rio Grande do Sul existe maior número de cooperativas mistas que atuam igualmente na produção e industrialização de erva-mate, dentro de seu objetivo de diversificação (Anuário Brasileiro da Erva-Mate, 2000).

No Rio Grande do Sul existem dois exemplos de organização de produtores de erva-mate que se uniram para superar dificuldades de comercialização. Em Machadinho, desde 1994 os produtores se uniram à Cooperativa Mista Ourense (Camol) e formaram a Associação dos Produtores de Erva-mate (Apromate). Reuniram-se 173 erveiros e organizaram em 1996 a indústria Cambona, construída em mutirão e financiada pela Camol. As operações iniciaram em 1997 no parque industrial da cooperativa que também está presente na venda do produto. Tal iniciativa agrega uma preocupação com a área técnica e, assim, criou-se núcleos de viveiristas e implantação de novos ervais para produtores integrados, com apoio da cooperativa, prefeitura e parceria com a universidade regional (Uni-Erechim) e Embrapa-Colombo/PR. A profissionalização do produtor é sugerida com a realização de cursos de manejo da cultura através de sindicatos rurais da região (Anuário Brasileiro da Erva-Mate, 2000).

No município de Venâncio Aires (RS), em 1997, os erveiros formaram o Departamento de Produtores de Erva-Mate do Sindicato dos Trabalhadores Rurais e em 2000 ativaram uma indústria com 57 matecultores, com apoio da Universidade de Santa 
Cruz do Sul (UNISC), por meio do Pólo de Modernização Tecnológica do Vale do Rio Pardo, bem como da Fundação de Amparo à Pesquisa no Rio Grande do Sul (FAPERGS), Banco Sicredi e Prefeitura (Anuário Brasileiro da Erva-Mate, 2000).

Iniciativas de organização como as citadas acima são necessárias e pertinentes para o estabelecimento e manutenção da cultura da erva-mate no Brasil. O fato da cultura ser praticada em grande parte por pequenos produtores, o agricultor familiar, alerta para o perigo que estes erveiros sofrem com as pressões e instabilidades do mercado com os preços, influenciados por mercados externos, como o da Argentina.

A produção em pequena escala faz com que eles não obtenham o valor do produto de uma forma justa, pois precisam repassá-lo a terceiros. No entanto, se os produtores se organizassem em cooperativas, poderiam industrializar sua própria produção e obter acesso aos lucros de forma mais justa.

\subsection{Das mudanças na agricultura à busca de um novo paradigma}

O modelo agrícola predominante praticado no mundo é um dos principais responsáveis pela degradação dos ecossistemas naturais. Na área de predominância da Mata Atlântica (floresta ombrófila mista) no estado do Paraná, pode-se observar um bom exemplo disso. No interior do estado, as áreas urbanas e as grandes áreas de monocultura agrícola substituíram os ecossistemas naturais, restringindo a ocorrência de florestas a remanescentes isolados, fragmentados e sustentavelmente ameaçados.

Segundo Ehlers (1996) a agricultura entrou na era moderna a partir do século XVIII, com a primeira Revolução Agrícola, e durante três séculos passou por intenso processo de transformações tecnológicas sociais e econômicas que gerou o fim do feudalismo europeu, alicerçou as sociedades européias e o capitalismo.

Em seguida, no século XIX, veio a segunda Revolução Agrícola permeada por grandes descobertas científicas e tecnológicas como: fertilizantes químicos, melhoramento genético de plantas e desenvolvimento de motores de combustão interna. A passagem da primeira revolução para a segunda deu-se às custas de uma ciência mecanicista, fragmentada e simplificadora do ambiente (Ehlers,1996). 
Depois da Segunda Guerra Mundial veio a chamada Revolução Verde caracterizada pela intensa mecanização da agricultura com maquinários específicos para determinadas culturas, a produção de híbridos que requeriam adubos químicos e a tecnologia que passou a ser estudada para aprender tudo isto.

As máquinas eram específicas e então o agricultor precisava se especializar em uma ou duas culturas no máximo, não podiam fazer mais rotação e consorciação de culturas, o que os levou às monoculturas (Primavesi, 1997). Porém, as monoculturas contribuíram para o aumento das pragas e doenças. Assim, para estas criaram-se “defensivos” como os organoclorados DDT, BHC e Aldrin que matavam tudo impiedosamente (Primavesi, 1997).

As monoculturas causam a simplificação do ambiente e o desequilíbrio dos ecossistemas e as pragas sobrepõe-se aos inimigos naturais sendo os danos inevitáveis. Esta necessidade urgente de combate às pragas leva, à aplicação de produtos químicos, os quais normalmente não são seletivos e, além de alterar a qualidade do produto final, acabam eliminando organismos não alvo, como os inimigos naturais (Berti Filho \& Krugner, 1986).

Quando Rachel Carson (1962) publicou seu famoso livro "Primavera Silenciosa”, apresentou aspectos de uma cidade degradada pela ação humana, onde já não havia mais passarinhos para cantar, nem borboletas a voar. As pragas foram se tornando resistentes e a indústria criou os organofosforados, os herbicidas, os dessecantes e assim por diante.

Com a agricultura tecnológica químico-mecânica que, além de cara, se tornou perigosa, os trabalhadores rurais perderam seus empregos sendo que nas últimas décadas, quatro bilhões de pessoas, em termos mundiais migraram para as cidades, amontoando-se em favelas e constituindo-se em mão de obra barata para indústrias multinacionais que surgiram aproveitando-se da miséria (Primavesi, 1997).

No Terceiro Mundo, este sistema não funcionou. Máquinas e adubos vieram do Primeiro Mundo, os subsídios dados inicialmente cessaram, os créditos e insumos ficaram caros e não houve a melhoria das condições socioeconômicas no hemisfério Sul. Atualmente muitos agricultores pequenos estão sendo dizimados pelos juros dos 
financiamentos para custeio de insumos e máquinas e suas terras estão sendo tomadas pelos bancos (Primavesi, 1997).

A Revolução Verde, até hoje traz conseqüências graves, pois dela se originaram vários problemas socioambientais que tendem a se perpetuar caso as práticas agrícolas não sejam revistas e caso a América Latina fique condicionada a aceitar passivamente as políticas de desenvolvimento dos países ricos que não se enquadram nas realidades locais e que são demasiadamente desumanas.

O Brasil tem exemplos de projetos que são incentivados pelo governo e que se intitulam provedores de "desenvolvimento", mas que na realidade causaram grandes desastres ambientais, como é o caso do projeto BR-364, em Rondônia, em que os agricultores, após a abertura da estrada migraram para Rondônia em busca de terras gratuitas, porém muitas terras deste local não são adequadas à agricultura e mesmo assim, foram desmatados, cerca de 20 milhões de hectares na década de 1980, uma ação facilitada através de subsídios do governo e sem estudos de impacto sobre a biodiversidade local (Primack \& Rodrigues, 2001).

Um outro exemplo de erros ambientais e falta de responsabilidade política do governo brasileiro, é a polêmica da "Estrada do Colono" no Paraná, a qual corta em uma extensão de 18 quilômetros o Parque Nacional do Iguaçu, foi reaberta em 1996 e fechada por uma decisão judicial em seguida. A justificativa das comunidades agrícolas da região para a permanência da estrada é que a floresta representa um obstáculo à expansão agrícola econômica da região e a preocupação com a conservação da biodiversidade local é irrelevante (Primack \& Rodrigues, 2001).

A concepção da agricultura moderna industrial não abrange biodiversidade e conservação. Mas perante tal concepção de agricultura, recai, nas últimas décadas uma forte pressão de uma nova linha de pensamento, de um despertar, da emergência de um novo paradigma para a agricultura mundial. Segundo Buttel et al, (1986) essa corrente que, pode ser chamada de agricultura alternativa, vem adicionar aos movimentos agrícolas do passado uma urgente conscientização sobre os aspectos ecológicos da agricultura. 
Tais aspectos ecológicos abrangem a preocupação com a conservação das espécies dos ambientes explorados, bem como a degradação e poluição do habitat e em linhas gerais o manejo, a conservação e o desenvolvimento sustentável das áreas exploradas (Primack \& Rodrigues, 2001).

Entretanto, a busca de uma outra agricultura não se limita apenas a um conjunto de medidas ecológicas, mas sim a um amplo contexto socioambiental, levando em conta as questões pertinentes ao cotidiano do agricultor, para que este seja sujeito deste processo e não um mero desempenhador de tarefas. Para tanto, existem princípios a serem considerados por esta nova expectativa de uma agricultura sustentável.

A homogenização das relações agro-ambientais causada pela agricultura convencional despreza as interações e as várias dimensões envolvidas na questão. As múltiplas diferenças sociais e culturais entre os bilhões de agricultores e camponeses do planeta, não são freqüentemente consideradas. Neste sentido, a uniformização deste modelo agrícola dominante foi constituindo-se em uma das maiores ameaças à sustentabilidade da agricultura e, conseqüentemente, à biodiversidade do planeta (Rosa, 2001)

Sabe-se que os problemas ambientais de hoje são, em grande parte, conseqüências dos processos adotados nas práticas agrícolas no decorrer dos anos. Um dos maiores problemas é a devastação das florestas nativas com espécies florestais de interesse econômico. Muitas delas foram exploradas pelos "colonizadores" e desbravadores”até ficarem próximas à extinção.

Segundo Primack \& Rodrigues (2001) o corte das florestas tropicais está constantemente associado à interesses internacionais dos países industrializados, pelos produtos agrícolas baratos como borracha, óleo, cacau e madeira. Em relação à Mata Atlântica brasileira, esta foi quase que inteiramente devastada para produção de cana-deaçúcar, cacau e café, restando apenas 5\% da floresta original.

Em muitas regiões do Brasil, assim como na região sudoeste do Paraná, as florestas foram eliminadas em troca do aumento de renda promovido pela agricultura industrial moderna e outras atividades econômicas. Os sistemas de produção passaram a contribuir para a degradação ambiental sem nem ao menos elevar a renda do agricultor. 
A agricultura moderna ganhou muito em termos de produção, mas há uma diversidade de impactos negativos que implicam na inviabilidade ecológica, agronômica, econômica e social do modelo a médio prazo, destacando-se: a contaminação dos recursos hídricos, a redução da biodiversidade, as intoxicações de trabalhadores rurais, a contaminação e perda da qualidade dos alimentos cultivados e vários problemas sociais (Paschoal, 1979; Graziano Neto, 1986; Altieri, 1989; Primavesi, 1992; Gliessman, 2000).

Ehlers (1996) considera que a agricultura sustentável tem um objetivo a longo prazo, pois está iniciando-se a transição ambiental, que será uma longa fase e não uma fase de mudanças aceleradas como nas revoluções. A partir desta compreensão, outros autores passam a abordar as discussões sobre as formas e etapas desta transição, ressaltando a importância da agricultura familiar, a qual deve ser fortalecida e incentivada. (Altieri, 1989; Ehlers, 1996).

Conforme Dunlap \& Beus (1990), as duas correntes de agricultura, convencional e alternativa, possuem práticas que são elementos-chave dos paradigmas em conflito na agricultura. Estes, por sua vez são antagônicos, baseados em princípios e valores culturais distintos. Enquanto a agricultura convencional pauta-se em Centralização, Competição, Dependência, Dominação da Natureza, Especialização e Exploração; a agricultura alternativa pauta-se em Descentralização, Independência, Comunidade, Harmonia com a Natureza, Diversidade e Conservação.

O atual modelo agrícola no Brasil, que é baseado nos princípios do convencional já caracterizado anteriormente, é decorrente de um processo histórico de colonização ocidental predatória. Santos ${ }^{2}$ citado por Sposati (2001) fala que no paradigma de capitalexpansionista o capital é visto como derivado do desenvolvimento econômico e neste a natureza é matéria valorizável como condição para a produção, a qual está assentada nos bens de produção. Esta concepção é predatória, autoritária e antidemocrática, pois assinala uma descontinuidade entre a natureza e a sociedade.

\footnotetext{
${ }^{2}$ Santos, Boaventura de Souza. A crítica da razão indolente. Contra o desperdício da experiência. São Paulo, Cortez, 2001.
} 
Essa relação de dominação do ser humano sobre a natureza ou a relação antropocêntrica, levou a humanidade à crise ambiental atual e a emergência de um novo paradigma, o qual Sposati (2001, p.20) baseada em Santos define: "pelo diálogo, pela satisfação das necessidades humanas fundamentais, pela baixa desigualdade e possibilidade de diversidade do padrão efetivo que a sociedade afiança à dignidade humana de todos".

Tanto no contexto urbano quanto no meio rural, o processo de mudança que visa à equidade social não será apreendido facilmente, o caminho a percorrer é o de uma utopia que é criticada pela racionalidade científica, pois a modernidade não capta a diferença e a possibilidade dos pequenos de transformar os seus espaços e o mundo.

\subsection{Estrutura da agricultura familiar do Paraná}

A procura por uma nova agricultura levou vários autores a analisar o lugar da agricultura familiar no processo de modernização, colocando no bojo das discussões a forma como a agricultura familiar foi afetada pelo processo de modernização. Segundo Graziano da Silva (1980), o padrão tecnológico adotado e difundido não foi adequado às necessidades da agricultura familiar, pois a estruturação da agricultura familiar não se enquadra no padrão tecnológico disponível. Isso porque o acesso à moderna tecnologia é limitado pela disponibilidade de terras, pelas condições dessa, pela escassez de recursos para investimentos e por requisitar maior quantidade de mão de obra. Além do fato de que não foram criadas tecnologias que pudessem adaptar-se a pequenas escalas de produção e de que não existem mecanismos políticos que viabilizem o acesso dos agricultores familiares à modernização. Também, o crédito, a pesquisa e a extensão caminharam em direção aos grandes produtores.

O espaço rural paranaense continua sendo marcado pela heterogeneidade estrutural e pela desigualdade social. A produção agropecuária e agroindustrial do estado faz, com que as questões do mundo rural sejam reduzidas a questões agrícolas e variáveis como preços, quantidades, financiamentos e outras. Porém, a pobreza do cenário rural do Paraná tem causas estruturais, ou seja, os problemas do mundo rural ultrapassam as questões agrícolas e inserem-se principalmente em questões agrárias. 
Segundo os dados do Incra $^{3}$ (2000), a agricultura familiar do Paraná detém $86,9 \%$ dos estabelecimentos rurais e $41 \%$ da área, enquanto a chamada agricultura patronal, detém 12\% dos estabelecimentos e 8\% da área.

No entanto, é importante compreender que a agricultura familiar apresenta enorme diversidade interna, como expressão dos diversos processos de reprodução social que condicionam a existência desta população. Fazem parte desta categoria, desde agricultores de subsistência, até aqueles tecnificados e com rendas semelhantes a pequenos empresários rurais (Diagnóstico Social e Econômico, 2000).

Conforme os dados do Diagnóstico Social e Econômico (2000), dentro do segmento familiar podem ser distinguidos mais três segmentos:

O primeiro, menor em termos numéricos ${ }^{4}$, é o mais importante em valor bruto de produção. É tecnologicamente moderno e fortemente articulado às agroindústrias, inclusive em regime de integração, demanda principalmente políticas para garantia de preços que garantam rendas e políticas de crédito diferenciadas que lhes permitam a manutenção e renovação de máquinas e equipamentos produtivos.

O segundo segmento sofre restrições estruturais, como pouca terra, precariedade de instrumentos de trabalho, mas ainda tem na agricultura e na produção agrícola seu elo principal com a sociedade. Demanda tanto políticas produtivas, para aumento de produção e renda, quanto políticas agrárias que melhorem a distribuição da terra.

O terceiro segmento, formado pelos mais pobres, provavelmente mantém-se na zona rural por falta de oportunidade de migração. Para sua permanência no espaço rural são necessárias políticas de desenvolvimento nos níveis locais, municipais,e regionais. A reforma agrária, ao redistribuir riqueza e renda, é um instrumento de promoção do desenvolvimento. Além da reforma agrária, algumas atividades agrícolas podem ser

\footnotetext{
${ }^{3}$ Segundo o Incra, são considerados agricultores familiares aqueles que possuem até 50 hectares de terra. Sendo assim, eles representariam 85,9\% dos estabelecimentos e 27,7\% da área. Ainda, os agricultores familiares seriam responsáveis por $48 \%$ do valor Bruto da Produção (VBP)..

${ }^{4}$ A quantificação desses segmentos da agricultura familiar depende dos critérios adotados para o dimensionamento da renda obtida e para a classificação em renda alta, média e baixa. Para o Incra, já citado, no Paraná os agricultores familiares de rendas maiores, Tipo A, representam 14,3\% dos estabelecimentos, 13,8\% da área e 28,6\% do VBP; os de renda média, Tipo B, detêm 27, $1 \%$ dos estabelecimentos, $12,9 \%$ da área e $12,3 \%$ do VBP; os agricultores de renda baixa e quase sem renda Tipos C e B - respondem por 45,5\% dos estabelecimentos, 14,2\% da área e 7,3\% do VBP.
} 
desenvolvidas em pequenas áreas e produzir rendas condizentes, a exemplo da produção de frutas e olerícolas.

O mercado tem grande influência na estrutura produtiva do estado, tendo uma forte tendência à concentração em commodities agrícolas. Porém, a agricultura estadual ainda apresenta uma razoável diversificação.

Em todas as regiões do estado a agricultura em regime de economia familiar é majoritária quanto ao número de estabelecimentos e de pessoal ocupado. Tomando a média estadual como parâmetro, as mesoregiões com maior presença da agricultura familiar, inclusive em termos de área e de estabelecimentos, são: Sudoeste, Oeste, Sudeste e Metropolitana de Curitiba , conforme pode ser observado na Tabela 1.

Tabela 1. Participação da Agricultura Familiar e da Agricultura Patronal no total de Estabelecimento e da Área, Segundo Mesorregiões - Paraná - 1995

\begin{tabular}{|c|c|c|c|c|c|c|}
\hline \multirow[b]{2}{*}{ Mesoregião } & \multirow[b]{2}{*}{$\mathrm{N}^{\circ}$. Estab. } & \multirow[b]{2}{*}{ Área (ha) } & \multicolumn{2}{|c|}{ Agricultura familiar } & \multicolumn{2}{|c|}{ Agricultura empresarial } \\
\hline & & & $\begin{array}{c}\mathrm{N}^{\circ} \text {. Estab. } \\
\%\end{array}$ & $\begin{array}{c}\text { Área (ha) } \\
\%\end{array}$ & $\begin{array}{c}\mathrm{N}^{\circ} . \text { Estab. } \\
\%\end{array}$ & $\begin{array}{c}\text { Área (ha) } \\
\%\end{array}$ \\
\hline Noroeste Paranaense & 38.835 & 2.248 .698 & 81,9 & 19,7 & 18,0 & 80,3 \\
\hline Centro-Ocidental Paranaense & 24.041 & 1.094 .808 & 83,2 & 25,7 & 16,8 & 74,3 \\
\hline Norte central Paranaense & 52.150 & 2.221 .214 & 83,9 & 27,6 & 16,0 & 72,4 \\
\hline Norte Pioneiro Paranaense & 30.689 & 1.365 .587 & 84,2 & 25,9 & 15,8 & 74,1 \\
\hline Centro Oriental Paranaense & 21.802 & 1.926 .463 & 79,2 & 11,6 & 20,8 & 88,4 \\
\hline Oeste Paranaense & 56.753 & 1.818 .237 & 88,3 & 38,9 & 11,7 & 61,1 \\
\hline Sudoeste Paranaense & 47.277 & 1.031 .602 & 92,8 & 58,1 & 7,2 & 41,9 \\
\hline Centro- Sul Paranaense & 38.660 & 2.141 .634 & 83,5 & 21,8 & 16,5, & 78,2 \\
\hline Sudeste Paranaense & 35.175 & 1.222 .317 & 88,0 & 38,0 & 12,0 & 62,0 \\
\hline Metropolitana de Curitiba & 24.493 & 876.073 & 89,0 & 31,0 & 11,0 & 69,0 \\
\hline Total do Estado & 369.875 & 15.946 .633 & 85,9 & 27,7 & 14,1 & 72,3 \\
\hline
\end{tabular}

Fonte: IBGE - Censo Agropecuário 1995/1996. 


\subsection{Os saberes e os sabores: a importância do etnoconhecimento}

Quando Leff (2002) escreve sobre a perspectiva agroecológica que se contrapõe aos modelos agrícolas da contemporaneidade, não está propondo uma nostalgia pelos tempos passados, mas sim uma contraproposta à homogenização que surge como conseqüência da globalização.

A produção em grande escala à revelia da intervenção da tecnologia na própria vida, na busca da produtividade e do lucro atrai pela aparência e sacia a fome de alguns consumidores, porém não apresenta sabor e, principalmente, não sacia a fome de toda população mundial.

Os pressupostos da agroecologia têm uma natureza social, uma vez que se apóiam em ações coletivas de determinados segmentos da sociedade civil, vinculados ao manejo dos recursos naturais e mediante as distintas formas de conhecimento, respeitando-as e incorporando-as.

Essa nova proposta é trazida pelo modelo referencial teórico proposto por Guzmán (2002).O autor apresenta três perspectivas para a pesquisa agroecológica: distributiva, estrutural e dialética. Conforme o autor, na pesquisa distributiva as variáveis relacionadas a fatores físicos e biológicos são controladas em estação experimental e, a partir daí, gera-se uma solução para o problema que posteriormente será apropriada pelos extensionistas que levarão aos agricultores, aos quais só resta aplicar as soluções técnicas geradas no laboratório.

Neste sentido move-se um discurso tecnológico onde as explicações têm um nível distributivo, em que se articula acervos quantitativos de conhecimento sobre o funcionamento dos recursos naturais. Estes dados são importantes, mas a agroecologia necessita completar os dados a partir da percepção dos produtores, uma vez que pretende-se mover, dentro do processo sociocultural da produção.

A perspectiva estrutural pauta-se na tentativa de explicar as relações existentes entre os fenômenos estudados, de acordo com a percepção dos sujeitos que intervêm nos mesmos, através da análise dos discursos construídos por estes. Assim, se gera uma 
informação qualitativa que dota de sentido sociocultural os processos gerados na realidade, sejam eles naturais ou sociais.

As palavras de Guzmán (2002, p.23) melhor explicam esta perspectiva:

(...) a perspectiva estrutural constitui um elemento central para a agroecologia, surgida como crítica à agricultura convencional, que ignora os sujeitos vinculados ao manejo dos recursos naturais. Essa ignorância é consequência do processo de cientifização a que foi submetido o manejo dos recursos naturais nos últimos anos e que desembocou na construção de um modo industrial de uso dos recursos naturais, que deteriora, gradualmente, tanto estes recursos como a sociedade. De fato, o discurso dos atores vinculados ao manejo dos recursos naturais é incorporado pela agroecologia através do grupo de discussão, da entrevista e das demais técnicas da metodologia qualitativa para mais tarde articular estas técnicas com a metodologia participativa e, ao fazê-lo, começa a construir uma alternativa ao fracassado modelo de agricultura industrializada”.

Assim, continuar ignorando os saberes dos sujeitos na realização das pesquisas precisa parar de acontecer. E quando se pergunta por que é importante valorizar o etnoconhecimento do agricultor, as propostas da agroecologia nos apontam respostas. Quando há um diálogo de saberes entre as comunidades locais e os pesquisadores na busca da solução dos problemas, juntos podem desenvolver métodos internos para soluções de problemas locais.

Guzmán (2002, p.25), afirma que a perspectiva dialética coloca que não se trata somente de conhecer e explicar, mas de intervir e articular-se com o objeto investigado para provocar uma transformação crítica. Conforme o autor, é preciso “dotar os agricultores do poder de participação” Para tanto, é preciso romper as relações de poder da ciência convencional: pesquisador-sujeito -que-sabe frente ao pesquisado-objeto-queignora.

Na busca da melhoria da qualidade de vida das populações rurais, a agroecologia apresenta propostas viáveis na resolução dos problemas e, conforme Leff (2002) 
convoca a um diálogo de saberes e intercâmbio de experiências para potencializar os agricultores, para articular os conhecimentos antropológicos, ecológicos, econômicos e tecnológicos.

\subsection{O ser humano e a natureza: caminhos apontados pela etnociência}

"Antes de tudo trata-se de considerar o homem como uma força da natureza, uma força entre outras. Seu interesse Ihe aconselha a estreitar as ligações, de permitir que as outras forças se desenvolvam, se renovem, em vez de esgotálas numa busca sem fim de energias a explorar e de espécies para destruir, de uma abundância que se transforma continuamente em escassez; de renunciar a esta atitude predatória tão fortemente ancorada nele".

Serge Moscovici

Moscovici ${ }^{5}$ citado por Diegues (2000) afirma que a visão naturalista está se transformando e passando de uma posição reativa e ingênua do mundo natural para uma visão ativa e a afirmação de uma nova relação entre homem e natureza. Para o autor, o que traz problemas não é o fato, mas a maneira como o homem intervém na natureza. A sociedade pertence à natureza, logo é a coletividade e não o indivíduo se relaciona com a natureza.

Dentre os novos conceitos e práticas que estão surgindo em busca de novos paradigmas de ciência não-linear encontra-se a etnociência. Segundo Marques (2001), as práticas da etnociência estão evoluíndo e consolidando-se em um método que emerge de campos interdisciplinares através do cruzamento de saberes que estão gerando novos campos. Assim, a etnociência não restringe-se a uma simples emersão de conhecimentos de várias disciplinas, mas epistemologicamente vem dar uma resposta concreta à crise do paradigma cartesiano de disciplinas que geram disciplinas.

\footnotetext{
${ }^{5}$ Moscovici, S.Hommes domestiques, hommes sauvages. Paris: Col. 10/18. 1974.
} 
A etnociência, no domínio científico, é relativamente nova. Seu surgimento data de cerca de 1950 na Universidade de Yale (EUA) no contexto de um movimento antropológico conhecido também como Antropologia Cognitiva, Nova Etnografia ou Etnografia Semântica (Diegues, 2000 e Costa Neto, 2002).

Lévi-Strauss (1987) foi um dos primeiros antropólogos que iniciaram os estudos na área de etnociência e, no Brasil, fez um estudo analisando o sistema de classificação dos indígenas sobre o uso das plantas na América do Sul Tropical.

A etnociência parte da lingüística para estudar o conhecimento das populações humanas sobre processos naturais (Diegues, 2000). Esta ciência revolucionou a conduta dos trabalhos de campo, pois através de seus métodos de análise se busca entender como o mundo é percebido, conhecido e classificado pelas diversas culturas humanas, procurando descobrir o pensamento e a maneira de ser do nativo. A importância dos estudos etnocientíficos baseia-se na afirmação de que toda sociedade se esforça para compreender o mundo ao seu redor (Costa Neto, 2002)

Mesmo que nas suas raízes a etnociência apresente muitos deslizes etnocêntricos em concepções mais tradicionais, ela tem sido praticada por associações interdisciplinares de pesquisadores e tem tido um papel importante nas etnografias do saber e das técnicas. Está superando abordagens essencialmente classificatórias e abrindo seu campo para pesquisas mais centralizadas na dinâmica das relações "ser humano/natureza”, incluindo abordagens também políticas de questões relativas a saberes e práticas de populações tradicionais e indígenas (Campos, 2002).

A etnociência (ou etnociências) vem exercendo um diálogo importantíssimo entre as ciências naturais e as ciências humanas e sociais, permitindo a criação de técnicas e métodos que contribuam cada vez mais para o avanço das pesquisas etnocientíficas (Marques, 2001).

No Brasil, os estudos do conhecimento tradicional sobre o mundo natural surgiram na década de 50 através da ecologia cultural, conforme descrito por Julian Stewart. Em seguida, por volta da década de 70, passaram a surgir trabalhos de etnociência dentro das diversas linhas e nelas está a subdivisão da Etnobiologia, que, 
segundo Diegues (2000), divide-se em: Etnobotânica, Etnofarmacologia, Etnomatemática, Etnoecologia e outras.

Conforme Marques (2001, p.49) a Etnoecologia é:

"O estudo das interações entre a humanidade e o resto da ecosfera, através da busca da compreensão dos sentimentos, comportamentos, conhecimentos e crenças a respeito da natureza, característicos de uma espécie biológica (Homo sapiens) altamente polimórfica, fenotipicamente plástica e ontogeneticamente dinâmica, cujas novas propriedades emergentes geram-lhe múltiplas descontinuidades com o resto da própria natureza. Sua ênfase, pois, deve ser na diversidade biocultural e o seu objetivo principal, a integração entre o conhecimento ecológico tradicional e o conhecimento ecológico científico”.

Em síntese, segundo Marques (2001) “(...) etnoecologia é o estudo científico do conhecimento ecológico tradicional”.

A diversidade de conceitos e abordagens que se encontram no campo da etnobiologia demonstra o quanto é difícil chegar a um consenso sobre seu universo de estudo. Segundo Posey (1986), a etnobiologia é uma forma ampla que se relaciona com o campo da ecologia humana, enfatizando categorias e conceitos cognitivos utilizados pelos povos em estudo.

Para Marques (2002), um bom praticante da pesquisa etnocientífica precisa ter uma competência múltipla no campo do saber que aparece após o "Etno"; ou seja, se você vai estudar etnoecologia, deve conhecer também de ecologia; se estudar etnozoologia, conhecer zoologia e assim por diante.

Costa-Neto (2002) afirma que a etnobiologia tem o papel de estudar as formas alternativas e marginais de conhecimentos e práticas correspondentes, quebrando o monopólio epistemológico imposto pela ciência moderna.O que afirma Posey (1986, pg.14) em seu artigo sobre etnobiologia, vale também para a etnociência e seus diversos desdobramentos: 
“(..) esta é a força e o objetivo da etnobiologia:promover um arcabouço teórico para integrar os diferentes subsetores das ciências naturais e sociais com outros sistemas científicos. Do ponto de vista filosófico, a etnobiologia serve de mediador entre as diferentes culturas, como uma disciplina dedicada a compreensão e respeito mútuo entre os povos”

Nesse sentido, o emprego da etnobiologia neste trabalho é uma tentativa de resgatar o conhecimento do agricultor/a, produtor de erva-mate, sobre os problemas fitossanitários enfrentados por eles, na perspectiva de indicar soluções norteadas pelo respeito e valorização do etnoconhecimento do agricultor/a.

\subsubsection{Etnoentomologia}

Nesta corrente de derivações da "etno” existe uma sub-área que particularmente interessa a este estudo: a etnoentomologia. Afinal, a entomologia é a ciência que se dedica ao estudo dos insetos e, neste trabalho, a entomologia foi empregada após o prefixo "etno", visando observar o etnoconhecimento do agricultor/a erveiro sobre os insetos, pragas e/ou inimigos naturais.

A Etnoentomologia caracteriza-se como o estudo transdisciplinar ${ }^{6}$ dos conhecimentos, dos comportamentos e crenças que intermediam as relações entre as populações humanas que as possuem e o mundo dos insetos. Os estudos desta área utilizam-se dos conhecimentos desenvolvidos e transmitidos pela tradição oral (Pacheco, 2001; Costa-Neto, 2002).

No campo das investigações etnoentomológicas observam-se pontos importantes: a percepção, os conhecimentos e as classificações dos insetos pelas sociedades humanas,

\footnotetext{
${ }^{6} \mathrm{O}$ conceito de transdisciplinariedade sucede a etapa interdisciplinar, pois neste as interações disciplinares acontecem num espaço sem as fronteiras disciplinares. O paradigma transdisciplinar impõe a necessidade de reconhecer a existência de todas as dimensões disciplinares presentes no processo de investigação (Silva, D. J. da. O Paradigma Transdisciplinar: Uma Perspectiva Metodológica para a Pesquisa Ambiental. In: Philippi Jr, A.; Tucci, C. E. M.; Hogan, D. J.; Navegantes, R. (Org.) Interdisciplinariedade nas Ciências Ambientais. Brasília: Ed PNUMA/MCT, 1999. p.71-107. 120p.
} 
bem como a importância cultural dos insetos incluindo o papel que cumprem em contos, mitos e crenças; a origem, os usos e o valor econômico dos insetos.

Em termos de biomassa, dominância numérica e ecológica os insetos podem ser considerados os principais constituintes dos ecossistemas terrestres desempenhando papéis chaves nos ecossistemas como, por exemplo, ciclagem de nutrientes e fluxo de energia, polinização, dispersão de sementes, regulação de populações de plantas e outros animais, além de representarem importantes fatores de pressão evolutiva (Price, 1984; Majer, 1987).

Os insetos são classificados em organismos invertebrados pertencentes à classe Insecta e caracterizados morfologicamente por apresentarem o corpo dividido em cabeça, tórax e abdome, por possuírem três pares de pernas e um par de antenas (Borror \& Delong, 1969). Constituem cerca de $75 \%$ da vida animal, sendo o maior grupo em número de espécies e abundância de indivíduos. Cerca de 900.000 espécies são conhecidas e há uma estimativa de que podem ser 10 milhões ou até o triplo deste valor (Wilson, 1992).

A conservação dos organismos invertebrados não é uma área que recebe muita atenção atualmente, talvez pelo conhecimento superficial da diversidade deste grupo por parte de biologistas da conservação (Hafernik Junior, 1992). O fato é preocupante porque existe uma enorme complexidade de interações desenvolvidas por estas milhões de espécies de insetos, bem como de artrópodes no geral, que não estão sendo consideradas e que sem as quais a maioria das outras espécies desapareceria da Terra, inclusive a espécie humana (Wilson, 1992).

Ao longo da história da espécie humana, os insetos vem sendo classificados em várias categorias, além das taxonômicas, conforme a relação que se estabelece entre os mesmos e o ser humano no ambiente que se inserem. A maioria destas classificações, dadas aos insetos pelo ser humano estão, baseadas nas relações que cada grupo humano estabelece com os insetos através do uso que faz destes seres vivos ou do modo como estes interferem na sua vida, lhe causando algum malefício ou benefício (Pacheco et al., 1998). 
Na literatura, existem vários trabalhos que tratam de etnoentomologia em populações tradicionais ${ }^{7}$ como Hogue (1987).; Posey (1987 a,b) e Costa Neto (2000); Porém, são escassos os trabalhos com populações ditas não-tradicionais e ainda populações camponesas, como agricultores, por exemplo.

Classificar os insetos como benéficos, maléficos, pragas ou não pragas vem muito desta relação antropocêntrica de dominação da natureza que impera ao longo da história do homem "civilizado", uma vez que rotular o meio ambiente é uma prática comum já que o ser humano não se sente parte integrante do meio.

Costa Neto (2002) coloca que, de modo geral, a visão negativa dos insetos é influenciada pelos meios de comunicação que, freqüentemente, mostram nas campanhas de indústrias de inseticidas que os insetos são organismos que devem ser exterminados indiscriminadamente. Assim, cada vez que a palavra inseto é mencionada, os indivíduos pensam logo em animais desagradáveis.

Kellert (1996) em um estudo sobre percepção ambiental estabeleceu algumas categorias de valores que as pessoas dão ao meio ambiente. $\mathrm{O}$ autor dividiu estas categorias em nove valores básicos: utilitários, naturalistas, ecológico-científicos, estéticos, simbólicos, dominadores, humanísticos, moralistas e negativistas. Segundo o autor, embora estes valores tenham se originado da biologia, eles são formativos, influenciados pela experiência e aprendidos na cultura. Esses valores podem refletir a constante busca do ser humano para filiar-se com a natureza e a vida selvagem.

Assim, atitudes mais positivas em relação aos insetos somente são observadas quando estes representam valores estéticos, utilitários, ecológicos e recreativos (Kellert, 1993).

Os insetos são classificados como pragas quando começam a causar danos a plantações agrícolas e florestais e também quando atingem o meio urbano, como por exemplo, cupins e formigas. Porém, eles se tornam praga porque seu ecossistema foi

\footnotetext{
${ }^{7}$ Populações tradicionais são definidas como populações de pequenos produtores que se constituíram no período colonial, freqüentemente nos interstícios da monocultura e dos ciclos econômicos. Com isolamento relativo, essas populações desenvolveram modos de vida particulares ... (Diegues,A. C. S. O Mito Moderno da Natureza Intocada. São Paulo: Hucitec. 1996.
} 
afetado, o equilíbrio biológico de pragas e inimigos naturais foi quebrado e, normalmente, isto se dá pela ação humana no meio (Berti Filho, 2001).

Assim como as populações tradicionais indígenas e não-indígenas, que vivem em contato mais próximo com a natureza, os camponeses agricultores, que trabalham com a terra, com plantações perenes, semi-perentes e culturas de curto ciclo, também, estabelecem uma relação com os insetos que acabam afetando suas plantações direta ou indiretamente, quando se tornam pragas. Essa relação pode ser positiva ou negativa, dependendo da visão deste agricultor sobre o inseto e da forma como este interferiu na sua produção.

A cultura da erva-mate, praticada em sua maior parte por pequenos e médios produtores rurais, também sofre o ataque de certas pragas, as quais podem causar danos consideráveis dependendo do grau de infestação. Porém, a relação estabelecida entre estes insetos e o produtor de erva-mate não é percebida e nem estudada.

Contudo, um estudo desta natureza poderia trazer soluções norteadas pelo manejo integrado, aliando conhecimento técnico e conhecimento do agricultor que podem contribuir para a preservação da biodiversidade destes invertebrados tão pouco valorizados e também para a manutenção da produção da erva-mate que é tradicionalmente consumida pelos habitantes da região sul e, que se apresenta como uma alternativa de renda para os pequenos e médios produtores rurais. 


\section{METODOLOGIA}

\subsection{O Método}

No instigante debate e nas discussões e questionamentos sobre a ciência e o fazer ciência, em pauta atualmente, critica-se muito a forma reducionista e simplista de perceber e analisar o mundo. Morin (2000) fala da importância de perceber a complexidade do conhecimento que é construído com incertezas e que a busca de verdades passa pela reflexão e integração do observador na observação.

Há algumas décadas os trabalhos antropológicos de campo eram marcados pela busca do exótico em contextos culturais distintos daqueles em que vivemos, porém o interesse etnográfico vem se deslocando para contextos urbanos, surgindo novos olhares e temas associados ao que vem sendo chamado de antropologia das sociedades complexas (Campos, 2002).

Diante da busca de novos caminhos para a ciência encontra-se o desafio de trabalhar as idéias, métodos e ações de forma menos fracionadas e mais relacionadas, captar a complexidade e saber lidar com ela, o que é um caminho que está em construção.

Segundo Minayo (1999), a hegemonia da ciência ocidental de construção da realidade ainda continua sem respostas e soluções para problemas essenciais como fome, miséria e violência. O que nos leva a refletir sobre a normatividade do campo científico das ciências naturais que provocam um embate às pesquisas sociais, questionando-as sobre sua objetividade.

Porém, nos fenômenos e processos sociais existe um sentido subjetivo, pois o objeto das ciências sociais é histórico, com configurações específicas das sociedades 
humanas no passado, presente e futuro. Ressalta-se que nas ciências sociais existe uma identidade entre sujeito e objeto. Trabalhar com seres humanos implica em envolver razões culturais, de classe ou faixa etária que promovem uma identidade entre investigador e investigado (Minayo, 1999).

A presente pesquisa utiliza-se de métodos das ciências sociais e tem um caráter também qualitativo, pois esta envolve a obtenção de dados descritivos do contato direto do pesquisador e a situação estudada. A pesquisa qualitativa caracteriza-se por “(...) trabalhar com o universo de significados, motivos, aspirações, crenças, valores e atitudes, o que corresponde a um espaço mais profundo das relações, dos processos e dos fenômenos que não podem ser reduzidos à operacionalização de vaiáveis” (Minayo, 1999, p.22).

Para Godoy (1995a) citado por Neves (1996), existe um conjunto de características que podem identificar uma pesquisa qualitativa: o ambiente natural como fonte direta de dados e o pesquisador como instrumento fundamental; o caráter descritivo; o significado que as pessoas dão às coisas e à sua vida como preocupação do investigador e o enfoque indutivo.

Em busca do que os números muitas vezes não conseguem dizer, esta pesquisa passa pelos processos qualitativos, acreditando-se no que Stewart (1995) afirma: ”(...) o número é apenas uma das enormes variedades de qualidades matemáticas que nos ajudam a entender e descrever a natureza”. Porém não se tem a intenção de afirmar aqui que o método quantitativo deva ser desprezado, pois se acredita que em certos trabalhos os quanti e quali se complementam e em outros é possível optar-se pelo que melhor se enquadra na pesquisa em uma abordagem equilibrada e responsável.

Duffy (1987, p.131) ${ }^{8}$, citado por Neves (1996) aponta cinco indícios do benefício de empregar métodos qualitativos e quantitativos em uma pesquisa:

\footnotetext{
${ }^{8}$ DUFFY, Mary E., Metthodological triangulation: a vehicle for merning quantitative and qualitative research methods, In Journal of Nursing Scholarship, 19 (3), 1987, pp. 130-133.
} 
1) "Possibilidade de congregar controle dos vieses (pelos métodos quantitativos) com compreensão da perspectiva dos agentes envolvidos no fenômeno (pelos métodos qualitativos);

2) Possibilidade de congregar identificação de variáveis específicas (pelos métodos quantitativos) com uma visão global do fenômeno (pelos métodos qualitativos);

3) Possibilidade de completar um conjunto de fatos e causas associadas ao emprego de metodologia quantitativa com uma visão de natureza dinâmica da realidade;

4) Possibilidade de enriquecer constatações obtidas sob condições controladas com dados obtidos dentro do contexto natural de sua ocorrência;

5) Possibilidade de reafirmar validade e confiabilidade das descobertas pelo emprego de técnicas diferenciadas”.

Silva (2001) apresenta em seu método o conceito de bricolagem, o qual trabalha com um conjunto de ferramentas metodológicas intencionando-se esclarecer os propósitos da pesquisa sobre múltiplas perspectivas, conforme Lapasse (1998).

Becker (1999) afirma que o cientista social deveria sentir-se livre para desenvolver seus próprios métodos e teorias à medida que as circunstâncias da pesquisa exigissem, pois cada pesquisa é muito singular.

Ardoino (1998, p.24), em sua perspectiva da multirreferencialidade propõe que a bricolagem é: uma leitura dos objetos sob diferentes pontos de vista, que implicam tanto visões específicas quanto linguagens apropriadas às descrições exigidas, em função de sistemas de referenciais distintos, considerados, reconhecidos, explicitamente como não redutíveis uns aos outros, ou seja, heterogêneos.

Lapasse (1998, p.136) sugere que a bricolagem seja uma abordagem a partir de perspectivas múltiplas e que "para aprender a pensar de forma multirreferencial, o aprendiz pesquisador deve aprender a bricolar”.

No intuito de aprender a bricolar trabalhou-se com técnicas da metodologia qualitativa, como as entrevistas, a análise documental e as observações livres. Por outro 
lado trabalhou-se também com técnicas utilizadas pela biologia, neste caso, as coletas dos insetos para posterior processamento em laboratório.

A entrevista é um dos métodos mais usuais no trabalho de campo. É uma técnica caracterizada pela comunicação verbal que reforça a importância da linguagem e do significado da fala. Através dela o pesquisador busca informações na fala dos investigados (Nogueira, 1975; Haquette, 1992 e Minayo, 1999).

É precisa a colocação de Macedo (2000, p.165):

“(...) a entrevista apresenta-se como um rico e pertinente recurso metodológico na apreensão dos sentidos e significados e na compreensão das realidades humanas, na medida em que toma como uma premissa irremediável que o real é sempre resultante de uma conceituação; o mundo é aquilo que pode ser dito, é um conjunto ordenado de tudo que tem nome, e as coisas existem através das denominações que lhe são emprestadas”.

De forma geral, as entrevistas podem se estruturadas, onde se trabalha com perguntas previamente formuladas, podem ser também semi-estruturadas, com perguntas pré-elaboradas, mas com a possibilidade de surgirem outras ao longo da conversa, ou ainda, podem ser abertas, onde o informante fala livremente do assunto proposto (Minayo, 1999; Macedo, 2000).

Durante as entrevistas utilizou-se de um recurso de imagem. Esta proposta surgiu das conversas com o pesquisador Carlos Rodrigues Brandão ${ }^{9}$, que ao analisar as perguntas propostas sugeriu que ao perguntar ao informante quais insetos ele conhecia, após sua resposta, lhe mostrasse algumas fotos de outros insetos (pragas e inimigos naturais), e em seguida perguntasse para verificar se os conhecia. Esta técnica assemelha-se aos testes projetivos que são também utilizados em etnopesquisas (Marques, 2001).

${ }^{9}$ Calos Rodrigues Brandão é .professor aposentado da UNICAMP, Pesquisador, antropólogo e profundo conhecedor de populações camponesas, tendo vários livros publicados na área. No ano de 2002 esteve na ESALQ/USP, realizando trabalhos em projeto no laboratório de Educação e Políticas 
Além de entrevistas, outro recurso utilizado para levantamento de dados secundários, foram análise de documentos da Secretaria da Agricultura e EMATER do Município de Salto do Lontra, além de dados da Secretaria da Agricultura do estado do Paraná e dados do Censo Agropecuário do IBGE. Estes são imprescindíveis na descrição do município em relação aos aspectos que circundam a cultura da erva-mate.

Segundo Macedo (2000), a análise de documentos na metodologia da etnopesquisa é um recurso precioso porque pode revelar novos aspectos do assunto ou aprofundar os já conhecidos, além de ser uma fonte de dados relativamente estável na pesquisa.

Fez-se uso, também, de anotações no caderno de campo, em que, na medida do possível, anotavam-se detalhes e frases chave que poderiam posteriormente esclarecer ou gerar uma pergunta sobre o estudo.

\subsubsection{Coleta dos dados Entomológicos}

Assim, quanto à obtenção dos dados entomológicos desta pesquisa, procedeu-se da seguinte maneira:

O experimento foi instalado em dois ervais plantados de propriedade particular, no município de Salto do Lontra-PR. O primeiro erval, denominado de erval 01 tinha sete anos de idade e as árvores apresentavam aproximadamente dois a três metros de altura com um espaçamento, entre as erveiras, de $2 \mathrm{~m}$ x 1,60m. Tal erval já sofreu duas podas, e era bem cuidado, com capinas e roçadas. Era circundado por um capão de mato. Foi selecionada uma área de 0,5 ha.

O segundo erval, denominado erval 02, tinha oito anos de idade e as árvores apresentavam aproximadamente dois a três metros de altura com um espaçamento, entre erveiras, de 2,5m x 1,60m. Este erval encontrava-se em estado de abandono, sofreu duas podas. Foi selecionada uma área de 0,5 ha

Ambientais do Departamento de Ciências Florestais onde tive a oportunidade de conhecê-lo e conversar sobre os aportes metodológicos de minha pesquisa. 
Para acompanhar um pouco da diversidade de insetos (pragas e inimigos naturais) no agroecossistema da erva-mate, foram instaladas nos dois ervais, em parcelas de 0,5 há, em palanques de 1,50 m de altura, 10 armadilhas modelo Gyrotrap 95 em cada erval, distribuídas nas laterais e no centro da parcela. Foram realizadas seis coletas quinzenais, de fevereiro a maio de 2003.

Sobre a escolha da armadilha, Prat Kricun (1986) e Chiaradia \& Milanez, (1997) testaram a utilização de armadilhas com diferentes cores para estudos de flutuação populacional e concluíram que armadilhas de cor amarela e vermelha são mais atrativas e sugeridas para estudos de monitoramento e flutuação populacional. Optou-se então pela confecção da armadilha de cor amarelo-escura

Os insetos coletados foram recolhidos das armadilhas quinzenalmente, acondicionados em frascos de filme fotográfico com álcool 70\% e, posteriormente, enviados ao laboratório onde os mesmos foram separados e identificados até a classificação taxonômica de família.

\subsubsection{O trabalho de campo}

Os caminhos metodológicos deste trabalho passaram pelo método etnográfico da antropologia, pois a etnografia foi empregada como uma maneira de portar-se perante os investigados que tinham sua própria cultura a ser aprendida e respeitada. Porém não se assume a etnografia como método único nesta pesquisa.

Também foram realizadas coletas de material biológico, neste caso de insetos, utilizando armadilhas já descritas anteriormente.

A escolha do município de Salto do Lontra deu-se devido a uma investigação prévia junto às secretarias municipais de agricultura da região e a conversas com técnicos, agrônomos e pessoas da comunidade em geral, no intuito de saber sobre a existência de famílias que tivessem plantações de erva-mate e que se utilizassem dela como uma fonte de renda complementar.

Nesta investigação prévia descobriu-se que neste município a Emater tinha desenvolvido um trabalho de incentivo ao plantio da cultura e à criação de viveiros de 
mudas, a cerca de sete anos atrás. Então, em novembro de 2002 foram feitos os primeiros contatos com a secretaria da Agricultura e a Emater deste município. Obtevese a informação de que muitos produtores no município haviam abandonado a cultura, mas que ainda existiam algumas famílias, cerca de dez a quinze, as quais possuíam ervais em cultivo.

Conseguiu-se então agendar com o agrônomo da Secretaria de Agricultura a ida para o município em fevereiro de 2003. Chegando lá, a recepção foi agradável e todos estavam ansiosos para saber o que se queria pesquisar em seu município. Explicou-se então ao Secretário da Agricultura, ao Gerente da Emater, ao Agrônomo e aos demais o que se queria pesquisar e como isto seria feito. Falou-se sobre as entrevistas com os agricultores e sobre as coletas entomológicas que perdurariam por quatro meses.

Um dos técnicos da Secretaria de Agricultura acompanhou a pesquisadora e foi feita uma listagem de nomes dos agricultores que tinham plantações de erva-mate e localidades que residiam para que pudessem ser visitados. Fez-se um planejamento das visitas que se seguiram nas semanas seguintes.

Intencionava-se ficar na zona rural, porém as distâncias de um local e outro não permitiram o trajeto a pé. Na cidade ficava-se com o veículo da Secretaria parcialmente à disposição.

Visitaram-se então as famílias, as quais distribuíam-se em comunidades rurais, como são agrupadas as populações rurais da região. Passou-se em seis comunidades: São Domingues, Linha Gonçalves, Linha Bernardi, Santa Rita, Nova Sessão e Linha Piscina.

Ao chegar aos sítios, a pesquisadora identificava-se, e, a presença do técnico da Secretaria fez com que os agricultores não se sentissem tão intimidados quanto a presença de um. Em geral, a recepção foi hospitaleira como é de característica das pessoas da zona rural na região.

Visitaram-se dez propriedades que tinham ervais e com autorização dos donos foi-se até a plantação e foram feitas se observações biológicas sobre a presença ou ausência de pragas, a disposição das plantas, o aproveitamento ou não para culturas consorciadas, etc. Em alguns casos percebeu-se o abandono total do erval. 
Foi então solicitado a cada agricultor visitado o agendamento de um dia para a entrevista, pois assim não atrapalharia seus trabalhos na lavoura.

As entrevistas semi-estruturadas foram feitas de fevereiro a março de 2003. Quase todas, com exceção de duas, realizaram-se em seus próprios sítios, nas dependências da sala, cozinha, e/ou varanda entre uma cuia de chimarrão e outra. Apenas uma entrevista não foi registrada em gravador cassete, a família não permitiu. Assim, registraram-se as informações no caderno durante a entrevista. Isto dificultou o andamento da conversa, pois falar, pensar e anotar é um exercício difícil.

Após percorrer seis comunidades e entrevistar 10 famílias de agricultores, optouse por encerrar esta parte da pesquisa, afinal as respostas já se repetiam e o número de famílias que plantam erva-mate no município também diminuía e os informantes não sabiam mais quem indicar. Também foram consideradas pertinentes as informações obtidas através de conversas informais com os técnicos da Secretaria sobre os aspectos que envolvem a cultura da erva-mate no município.

É pertinente registrar aqui as dificuldades de financiamento da pesquisa, as quais limitaram a permanência no campo, impedindo uma observação mais intensa e impossibilitando a observação participante utilizada neste tipo de pesquisa. Porém procurou-se atender os objetivos propostos sem perder o rigor que este tipo de pesquisa implica, trabalhando-se dentro das limitações que os dados apresentam.

Depois de concluídas as entrevistas, foi retornado à Piracicaba para sua transcrição e posterior análise.

Em julho de 2003 retornou-se ao município em busca de mais dados secundários para a melhor caracterização da área e o contexto de estudo.

\subsubsection{A Análise dos Dados}

A opção de análise dos dados qualitativos, obtidos nas entrevistas, foi à categorização do conteúdo das respostas. Segundo Bradley (1993) e Minayo (1999), trabalhar com categorias significa agrupar elementos, idéias ou expressões em torno de um conceito capaz de abranger tudo isso. Conforme Patton (1980), os dados são 
organizados em categorias descritivas e a interpretação envolve a atribuição de significado à análise, explicando os padrões encontrados e procurando por relacionamentos entre as dimensões descritivas.

Nesse sentido, as entrevistas que foram gravadas, foram posteriormente transcritas literalmente e categorizadas, agrupando-se todas as respostas de cada pergunta feita e em seguida, explorando pontos que mais se destacaram na fala dos entrevistados. Convém ressaltar que tal trabalho exigiu uma leitura e muitas outras releituras, mergulhando nas falas e no contexto para que fosse possível aplicar a análise.

As informações obtidas nas entrevistas estão sendo articuladas com as informações de outras conversas, de documentos e de idéias de autores e a este processo chama-se triangulação dos dados que consiste na utilização de várias estratégias de amostragem para que se chegue às interpretações nas especificidades estudadas.

Visando demonstrar um pouco da diversidade biológica de famílias da entomofauna na região de Salto do Lontra, encontradas nos ervais um e dois foi utilizado o Índice de Diversidade (H’) (Magurran, 1988).

$$
H^{\prime}=-\sum_{i=1}^{S}[(n i / n) \ln (n i / n)] \text {; }
$$

Sendo:

$$
\begin{aligned}
& n_{i}=\text { número de insetos } i \\
& n=\text { número total de insetos. }
\end{aligned}
$$

\subsection{Caracterização da área de estudo: o município de Salto do Lontra}

Segundo registros da Prefeitura Municipal (1998), por volta de 1951 chegaram as primeiras famílias que iniciaram a colonização e a fundação da Vila. A origem do nome teria surgiu devido à existência de lontras no rio, perto da vila que ora se iniciava. No mesmo rio há um salto, uma queda d'água, da qual surgiu então o nome "Salto do Lontra”. As primeiras famílias eram: Nicolau Inácio; Benjamim Fabrício; Estevão 
Dorigoni; Helmut Sauer; João Cruz; Danilo Chiamet; Alípio Fabrício; Dorvalino Telles e Júlio Barone.

Atualmente o município é composto por vinte e quatro comunidades rurais, sendo elas: São Sebastião; Sede Luz; São Domingos; Santa Terezinha; Linha Gonçalves; São Jorge; Pinhal da Várzea; Barra do Lontra; Linha Boeira; Linha dos Gaúchos; Nova Sananduva; Nova União; Alto Rio Bandeira; Linha $1^{\circ}$. De Maio São Roque; São João do Cotegipe; Sananduva; Alto Sananduva; São Pedro do Bandeira; São Valentim; Linha Carmélia; Linha Toscan; Cordilheira do Lontra; Pio X (Prefeitura Municipal, 1998)

O município de Salto do Lontra situa-se a $25^{\circ} 46$ ",latitude S e a $55^{\circ} 19^{\prime} 40^{\prime}$, longitude W. Pertence ao estado do Paraná e está localizado na região Sudoeste.

A superfície do município é de $335 \mathrm{Km}^{2}$. Essa área corresponde a 0,2\% da área total do estado.

A população do município é de 15.637 habitantes dividida entre população urbana de 10.437 e rural de 5.200 habitantes, segundo censo demográfico do IBGE, (2000).

Localiza-se a 500 metros acima do nível do mar e a $536 \mathrm{Km}$ da capital. Ao Norte, limita-se com o município de Nova Prata do Iguaçu, ao Oeste com Santa Izabel do Oeste, ao Leste com Dois Vizinhos, ao Sul com Nova Esperança do Sudoeste (Prefeitura Municipal, 1998).

O relevo do município apresenta-se numa percentagem de $6 \%$ plano; $15 \%$ suave ondulado; $40 \%$ ondulado; $25 \%$ acidentado; $9 \%$ montanhoso e $5 \%$ escarpado.

O solo e o subsolo dividem-se da seguinte maneira:

Solos Litálicos - Solos rasos, sem horizonte - encontrado em relevos acidentados, montanhosos e escarpado. Solos Latossolo roxo: Solos profundos; relevo plano; suave e ondulado.

O clima caracteriza-se como clima subtropical Úmido Mesotérmico, com verões quentes e geadas pouco freqüentes e com tendência de concentração das chuvas nos meses de verão, sem estação seca definida. A média das temperaturas nos meses mais quentes é superior a $22^{\circ} \mathrm{C}$ e nos meses mais frios é inferior a $18^{\circ} \mathrm{C}$. 
O município possui os rios Lontra e Jacaratiá com seis afluentes: rio dos micos, rio cortegipe; rio dos porcos; rio mambuco, rio quebra dente; rio bandeira (Prefeitura Municipal, 1998).

Quanto a pluviosidade, a média anual é de $60 \mathrm{~mm}$ com menor precipitação de $25 \mathrm{~mm}$ no mês de agosto e maior precipitação de $150 \mathrm{~mm}$ no mês de outubro (Prefeitura Municipal, 1998).

\subsubsection{Economia do Município}

Assim como a maioria dos municípios da região Sudoeste do Paraná, o município de Salto do Lontra possui uma economia basicamente subsidiada pela agricultura.

Segundo os dados da Secretaria de Agricultura e Abastecimento do Estado do Paraná - SEAB (2003), a produção agrícola do município desde 1994 até o ano de 2002 pode ser expressa na Tabela 2. Observando-se que os principais produtos agrícolas do município são feijão, milho, soja, trigo, sementes e mandioca.

Quanto à situação dos ervateiros da região sudoeste do PR, é semelhante a demais regiões da zona produtora. Os ervais nativos/sombreados produzem um desfrute industrial superior aos ervais cultivados a pleno sol. Também, os atributos sensoriais são diferenciados, em especial o atributo amargor menos suave proveniente dos ervais cultivados a pleno sol.

Além dos preços médios negociados favoráveis aos ervais nativos/sombreados, as indústrias não processaram erva-mate durante a safrinha Dezembro/Janeiro/Fevereiro (2003), o que promoveu a erradicação dos ervais em solos agricultáveis, sendo substituídos por soja e milho, imbatíveis em valor, no mercado externo.

No município de Salto do Lontra, em que a cultura não é uma das principais fontes de renda do setor agrícola, a situação acima citada vem ocorrendo entre os produtores, alguns já abandonaram a cultura trocando-a por outras mais rentáveis economicamente. 
Tabela 2. Produção agrícola do Município de Salto do Lontra nos anos de 1994 a 2002

\begin{tabular}{|c|c|c|c|c|c|c|c|c|}
\hline \multirow{2}{*}{ CULTURA } & \multicolumn{8}{|c|}{ SAFRA AGRÍCOLA } \\
\hline & 1994/1995 & $1995 / 1996$ & 1996/1997 & 1997/1998 & 1998/1999 & $1999 / 2000$ & $2000 / 2001$ & $2001 / 2002$ \\
\hline Abacate* & - & - & - & 20,00 & 40,00 & 40,00 & 40,00 & 40,00 \\
\hline Abóbora* & - & - & - & - & 300,00 & 340,00 & 380,00 & 380,00 \\
\hline Acelga* & - & - & - & - & - & 30,00 & 30,00 & 30,00 \\
\hline Alface* & - & 12,00 & 24,00 & 24,00 & 40,00 & 40,00 & 40,00 & 80,00 \\
\hline Algodão* & 435,00 & 32,00 & - & - & 30,00 & 24,00 & 22,00 & 10,00 \\
\hline Alho* & 12,00 & 12,00 & 9,00 & 9,00 & 9,00 & 9,00 & 9,00 & 6,00 \\
\hline Amendoim* & 11,00 & 11,00 & 11,00 & 8,00 & 8,00 & 12,00 & 78,00 & 8,00 \\
\hline Arroz* & 540,00 & 540,00 & 144,00 & 200,00 & 200,00 & 200,00 & 176,00 & 144,00 \\
\hline Aveia* & 40,00 & 40,00 & 40,00 & 120,00 & 160,00 & 80,00 & 240,00 & 400,00 \\
\hline Banana* & - & - & - & 150,00 & 200,00 & 200,00 & 100,00 & 280,00 \\
\hline Batata* & 78,00 & 78,00 & 78,00 & 78,00 & 78,00 & 78,00 & 78,00 & 78,00 \\
\hline Batata Doce* & 1900,00 & 3520,00 & 3520,00 & 3520,00 & 480,00 & 640,00 & 640,00 & 640,00 \\
\hline Beterraba* & - & - & - & - & - & 60,00 & 60,00 & 60,00 \\
\hline Cana-de-Açúcar* & 2250,00 & 2250,00 & 2250,00 & 2250,00 & 2500,00 & 500,00 & 2500,00 & 2500,00 \\
\hline Caqui* & - & - & - & 7,00 & 25,00 & 30,00 & 30,00 & 30,00 \\
\hline Cebola* & 40,00 & 41,00 & 41,00 & 50,00 & 41,00 & 45,00 & 45,00 & 45,00 \\
\hline Cebolinha Verde* & - & - & - & - & - & 10,00 & 10,00 & 10,00 \\
\hline Cenoura* & - & - & - & 20,00 & 20,00 & 60,00 & 60,00 & 60,00 \\
\hline Chuchu* & - & - & - & - & 30,00 & 40,00 & 40,00 & 40,00 \\
\hline Couve* & - & - & - & - & - & 15,00 & 15,00 & 15,00 \\
\hline Couve-Flor* & - & - & - & - & 20,00 & 80,00 & 80,00 & 80,00 \\
\hline \multicolumn{9}{|l|}{ Erva-Mate (Folhas) } \\
\hline * & 162,00 & 182,52 & 67,75 & 75,00 & 145,00 & 153,50 & 185,48 & 540,00 \\
\hline Feijão* & 16200,00 & 5400,00 & 5810,00 & 4500,00 & 2170,00 & 1604,00 & 2290,00 & 1080,00 \\
\hline Feno de Alfafa* & - & - & - & - & - & 20,00 & 20,00 & 20,00 \\
\hline Figo* & - & - & - & 10,00 & 16,00 & 16,00 & 16,00 & 16,00 \\
\hline Forragem Verde* & - & - & - & - & 5800,00 & 9000,00 & 11500,00 & 15000,00 \\
\hline Fumo* & 98,00 & 310,00 & 310,00 & 387,00 & 501,00 & 630,00 & 633,00 & 901,00 \\
\hline Laranja* & 240,00 & 120,00 & 250,00 & 280,00 & 285,00 & 290,00 & 290,00 & 290,00 \\
\hline Limão* & - & - & 30,00 & 60,00 & 60,00 & 60,00 & 60,00 & 60,00 \\
\hline
\end{tabular}


Tabela 2. Produção agrícola do Município de Salto do Lontra nos anos de 1994 a 2002.

\begin{tabular}{|c|c|c|c|c|c|c|c|c|}
\hline Madeira*** & 26255,00 & 26130,00 & 21087,00 & 19577,00 & 20102,00 & 23155,00 & 26135,00 & 37574,00 \\
\hline Mamão* & - & - & 40,00 & 30,00 & 100,00 & 100,00 & 50,00 & 50,00 \\
\hline Mandioca* & 8500,00 & 8500,00 & 13750,00 & 12500,00 & 18750,00 & 18750,00 & 20250,00 & 11000,00 \\
\hline Maracujá* & - & - & - & - & - & 40,00 & 8,00 & 8,00 \\
\hline Melancia* & 300,00 & 300,00 & 286,00 & 660,00 & 660,00 & 750,00 & 900,00 & 900,00 \\
\hline Melão* & 4,00 & 3,00 & 4,00 & 4,00 & 6,00 & 16,00 & 20,00 & 20,00 \\
\hline Milho* & 57400,00 & 35200,00 & 25200,00 & 21250,00 & 33000,00 & 32700,00 & 45612,00 & 23862,00 \\
\hline Moranga* & - & - & - & - & - & 100,00 & 100,00 & 100,00 \\
\hline Morango* & - & 2,00 & 4,00 & - & - & 6,00 & 8,00 & 16,00 \\
\hline Mudas (Outras)** & 13000,00 & 17000,00 & 62490,00 & 363887,00 & 116930,00 & 95815,00 & 99947,00 & 142844,00 \\
\hline Mudas De Erva & & & & & - & - & - & - \\
\hline Mate** & 180000,00 & 305000,00 & 513000,00 & 12800,00 & & & & \\
\hline Noz Pecan* & - & - & - & - & - & 5,00 & 5,00 & 5,00 \\
\hline Ornamentais** & - & - & - & - & - & 10000,00 & - & - \\
\hline Pepino* & - & - & - & - & 30,00 & 100,00 & 100,00 & 100,00 \\
\hline Pêra* & - & - & - & 20,00 & 25,00 & 25,00 & 25,00 & 25,00 \\
\hline Pêssego* & 21,00 & 16,00 & 24,00 & 30,00 & 30,00 & 30,00 & 30,00 & 30,00 \\
\hline Pimentão* & - & - & - & - & - & 15,00 & 15,00 & 15,00 \\
\hline Repolho* & 40,00 & 95,00 & 114,00 & 114,00 & 120,00 & 240,00 & 400,00 & 400,00 \\
\hline Salsa* & - & - & - & - & - & 10,00 & 10,00 & 10,00 \\
\hline Sementes* & - & 640,00 & 62,00 & 143,00 & 740,00 & 1090,00 & 503,00 & 2057,00 \\
\hline Soja* & 5600,00 & 8360,00 & 10738,00 & 12000,00 & 8400,00 & 7800,00 & 9972,00 & 16720,00 \\
\hline Sorgo* & - & - & - & - & - & - & - & 300,00 \\
\hline Tangerina Ponkan* & - & 36,00 & 72,00 & 50,00 & 48,00 & 48,00 & 50,00 & 50,00 \\
\hline Tomate* & 40,00 & 20,00 & 20,00 & 20,00 & 20,00 & 30,00 & 31,00 & 32,00 \\
\hline Trigo* & 960,00 & 4000,00 & 960,00 & 700,00 & 650,00 & 1200,00 & 1820,00 & 1930,00 \\
\hline Triticale* & 400,00 & - & - & - & - & - & 15,00 & 68,00 \\
\hline Uva* & 82,00 & 75,00 & 82,00 & 150,00 & 150,00 & 150,00 & 150,00 & 160,00 \\
\hline Vassoura* & - & - & - & - & - & 50,00 & 52,00 & 55,00 \\
\hline
\end{tabular}

Fonte: SEAB/DERAL, 2003.

*Valores em toneladas; **Valores em unidades; ***Valores em metros cúbicos $\left(\mathrm{m}^{3}\right)$ 


\subsubsection{Estrutura fundiária}

Segundo os dados do IBGE, fornecidos pela Secretaria de Agricultura e Abastecimento do Estado do Paraná, a estrutura fundiária do município pode ser representada na Tabela 3:

Tabela 3. Estrutura fundiária do Município de Salto do Lontra

\begin{tabular}{|c|c|c|c|c|c|c|c|c|c|c|}
\hline 0 a 5 & 5 a 10 & 10 a 20 & 20 a 50 & 50 a 100 & 100 a 200 & 200 a 500 & 500 & 1000 & & AL \\
\hline ha & ha & $\mathrm{n}^{0}$ & $\mathrm{n}^{\mathbf{0}}$ & $\mathrm{n}^{\mathrm{o}}$ & $\mathrm{n}^{\mathrm{o}}$ & $\mathrm{n}^{0}$ & $\mathrm{n}^{\mathrm{o}}$ & ha & $\mathrm{n}^{\mathrm{o}}$ & Há \\
\hline 1572 & 3557 & 7065 & $303 \quad 8787$ & 4016 & 2793 & 518 & 2 & 1486 & 1866 & 29794 \\
\hline
\end{tabular}

Fonte: IBGE - Censo Agropecuário 1995/1996

$\mathrm{n}^{\mathrm{o}}$ : Número de estabelecimentos

ha: Área em hectares

\subsection{Caracterização dos sujeitos da pesquisa}

Para apresentar os sujeitos desta pesquisa, os/as agricultores/as entrevistados/as, optou-se pela não utilização do nome verdadeiro destes, preservando sua identidade.

Em virtude dos aspectos etnoentomológicos deste trabalho denominou-se cada agricultor/a com o nome popular de insetos que foram citados por eles nas entrevistas. As informações apresentadas a seguir foram fornecidas pelos próprios entrevistados. Assim:

Pulgão: Sexo masculino, tem 45 anos de idade, casado, tem três.filhos, sua propriedade fica na linha São Domingues e tem cerca de 40ha.

Besouro: Sexo masculino, casado, tem 52 anos.de idade, dois.filhos, sua propriedade fica na linha São Domingues e tem aproximadamente 35ha

Vespa: sexo masculino, tem 57. anos de idade, casado, quatro.filhos, sua propriedade fica na Linha Gonçalves e tem cerca de .20ha.

Louva-deus: Sexo masculino, casado, cinco.filhos, 60 anos.de idade, sua propriedade fica na Linha Bernardi e possui cerca de 50ha. 
Fede-fede: Sexo masculino, solteiro, sem filhos, tem quatro.irmãos, mora com os pais, tem 28 anos, a propriedade de sua família fica na Linha Piscina e tem aproximadamente 26ha.

Bicudo: Sexo masculino, casado, três.filhos, 45 anos de idade, sua propriedade fica na comunidade Santa Rita e tem cerca de 32ha.

Borboleta: Sexo masculino, casado, tem três filhos, sua propriedade fica na comunidade Nova Sessão e tem cerca de .28ha.

Abelha: Sexo masculino, casado, dois filhos, 40.anos de idade, sua propriedade fica na Linha Piscina e tem cerca de 25 ha

Formiga: Sexo masculino, casado, quatro filhos, 43.anos, sua propriedade fica na comunidade Nova Sessão e tem cerca de 32 ha..

Joaninha: Sexo feminino, 45anos de idade, casada, três filhos, sua propriedade fica na comunidade São Domingues.e tem aproximadamente 31ha.

Lagarta: Sexo masculino, casado, 70.anos de idade, oito filhos, sua propriedade fica na comunidade São Domingues e tem cerca de 31 ha. 


\section{RESULTADOS E DISCUSSÃO}

Neste capítulo apresentam-se os resultados e discussões sobre o etnoconhecimento do agricultor/a, produtor de erva-mate, em relação aos insetos associados ou não com a erva, com base na interpretação das falas dos entrevistados.

Apresentam-se também os aspectos ecológicos e socioeconômicos dianosticados ao longo deste trabalho, nas coletas entomológicas, nas observações livres e nas entrevistas. Busca-se a compreensão da situação local com o auxílio de autores que contribuíram na realização deste estudo subsidiando as análises.

\subsection{Aspectos etnoentomológicos}

\subsection{Otnoconhecimento do agricultor erveiro em relação aos insetos praga e inimigos naturais}

Percebe-se pelos dados apresentados na Tabela 4 que os agricultores citam vários insetos que são comuns em seu dia-a-dia no campo, como lagartas, vaquinhas pecevejos, libélulas e lembram-se de algumas pragas da erva-mate como a ampola, pragas de outras culturas como soja, milho e mandioca. Porém não apresentam maiores detalhes sobre os insetos em todas as falas, apenas naquelas situações em que o inseto lhe causou algum dano maior como o "besouro agrimensor e a ampola", por exemplo. Assim o desenvolvimento da cognição feita pelo agricultor em relação ao inseto não é forte e nem estruturado o suficiente para afirmar que ele conhece profundamente o que está falando, ao menos que o inseto tenha lhe prejudicado, atacando suas plantações.

Os agricultores ao olharem as fotos dos insetos mostradas durante a entrevista conseguem fazer cognições mais refinadas apresentando então maiores detalhes dos insetos que conhecem. Falam sobre o inseto e algumas características corroboram com as citadas na literatura consultada conforme se observa na Tabela 5. 
Tabela 4. Comparações entre o conhecimento popular dos agricultores sobre os insetos associados ou não com a erva-mate com a taxonomia e características apresentadas pela literatura

\begin{tabular}{ccc}
\hline $\begin{array}{c}\text { Nome popular ou } \\
\text { característica atribuída a um } \\
\begin{array}{c}\text { inseto pelo agricultor na } \\
\text { entrevista. }\end{array}\end{array}$ & Taxonomia & Características do inseto apresentada na literatura consultada \\
\hline o bicudo da soja & $\begin{array}{l}\text { Sternechus subsignatus } \\
\text { (bicudo da soja) }\end{array}$ & $\begin{array}{l}\text { Tanto adultos como larvas atacam a haste principal da soja, desfiam o tecido resultando em anelamento } \\
\text { característico, onde realizam a postura, as larvas desenvolven-se no interior da haste broqueada, } \\
\text { provocando enfraquecimento das plantas (Gallo et al., 2002). }\end{array}$
\end{tabular}

“eu tenho uma criação de abelha Apis mellifera que elas gosta muito da flor”.

"Eu vi inseto na erva depois que Gyropsylla spegazziniana comecei a plantar muda, ela forma assim, tipo dum negócio que arrepia a folha (ingruma) e ali dentro nasce um inseto".

“Olha, eu não sei o nome, mas é um negocinho branco assim que sai nos primeiros broto da erva e até hoje ainda tem”.” também dá essa pestinha da ampola que teve uns ano que atacou bastante...”.
Inseto útil, devido à produção do mel e alimentos naturais com alto valor energético. A perspectiva brasileira com essa atividade é bastante promissora devido ao fato de nossa flora ser uma das maiores e mais ricas do mundo, associada à condições climáticas propícias”(Gallo et al., 2002).

São conhecidos como ampola-da-erva-mate, por formarem cecídeas em suas folhas. São insetos pequenos que sugam seiva dos ramos da erva-mate, e suas formas jovens atacam as folhas, onde causam deformações, ficando essas folhas fechadas. No interior das ampolas encontra-se as formas jovens que são ápteras e sugam continuamente a seiva do local. Atacam tanto no viveiro quanto no campo. Deformam as brotações e impedem seu desenvolvimento obrigando a planta a emitir novas brotações” (Penteado et al., 2000 e Gallo et al., 2002). 
Tabela 4. Comparações entre o conhecimento popular dos agricultores sobre os insetos associados ou não com a erva-mate com a taxonomia e características apresentadas pela literatura

"tem o fede-fede”. "Tem percevejo“ Nezara viridula percevejo São percevejos que medem cerca de 13 a 17 mm de comprimento, apresentam coloração verde, verde ou fede-fede com a face ventral verde clara e antenas avermelhadas. As formas jovens têm o hábito de aglomerar-se sobre as plantas. Desde que nascem alimentan-se da seiva, introduzindo seu aparelho bucal nos tecidos das folhas, hastes e frutos, provocam retenção foliar, devido a toxinas que injetam, as folhas não caem normalmente e dificultam a colheita mecânica (Gallo et al., 2002)

"vaquinha, e lagarta* são vários Cerotoma tipos”.

arcuatus São besouros de 5 a $6 \mathrm{~mm}$ de comprimento, de coloração amarela com manchas pretas nos élitros. Atacam de preferência as folhas mais tenras, nas quais abrem grande número de pequenos orifícios. Quando o ataque é muito intenso, observa-se um atraso no desenvolvimento das plantas. Pode atacar vagens de soja (Gallo et al., 2002).

“Faz um ano ou dois tinha surgido Lagarta-rabuda uma lagarta na folha da erva, uma lusca lagarta meio grossinha de uns 3 ou Sphingidae) $4 \mathrm{~cm}$ de comprimento que eu matei”.

“ O nome do inseto eu não sei, mas eu olho muito aquele bisoro que corta muito bem, ele é um agrimensor” tem a lagarta*...
Perigonia São lagartas que medem até 60mm de comprimento. Têm coloração verde-amarelada, com faixa (Lepidoptera: dorsal longitudinal branca ou escura e áreas laterais com finas listras amareladas. Apresentam, no oitavo segmento abdominal, um prolongamento de coloração avermelhada. Empupam no solo, na área de projeção da copa. Os adultos são acinzentados, com faixas escuras nas asas anteriores e com uma mancha amarela na asa posterior. Os adultos surgem principalmente na primavera e são de hábito noturno e desenvolvem-se pelo menos duas gerações anuais durante a primavera e verão, podendo ser observada uma terceira no outono. (Fernandez Diaz, 1997; Penteado et al, 2000; Alves, 2001 e Gallo et al, 2002).

Coleoptera: Cerambycidae. São chamados longicórnios, mas o nome mais comum é serra-paus. A maioria das espécies ultrapassa 20mm, vivem em geral junto às plantas onde se criam, alimentando-se de pólen ou frutos já abertos. A maioria não é nociva na fase adulta, a não ser espécies denominadas serradoras que preparam os ramos para a postura (Gallo et al, 2002). 
Tabela 4. Comparações entre o conhecimento popular dos agricultores sobre os insetos associados ou não com a erva-mate com a taxonomia e características apresentadas pela literatura

" libélula”. $\quad$ Ordem Odonata $\quad$ Reúne os insetos conhecidos vulgarmente por libélulas. Corpo alongado com cerca de 20 a 160mm de comprimento..Alimentan-se de outras espécies de insetos caçando suas presas durante o vôo, com grande voracidade. A postura é feita na água mas pode ser no interior das plantas ou sobre as plantas. (Gallo et al, 2002).

“tem lagarta da mandioca”

Mandarová Erinnyis ello

É a principal praga da mandioca, sendo conhecida também por gervão. Suas mariposas são grandes, de coloração cinza com faixas pretas no abdome. Suas lagartas têm coloração variando de verde, marrom a preta e atingem até $100 \mathrm{~mm}$ de comprimento. Atacam as folhas de todas as idades, desfolham as plantas podendo destruir também os ramos mais finos (Gallo et al, 2002).

“Cigarrinha”**

“Tem ruga do fumo”*

*Lagarta é o estagio de larva dos insetos da Ordem Lepidoptera, mais conhecidas por borboletas e mariposas. Existem vários tipos de lagartas, por isto é impossível saber de qual lagarta eles/as estão se referindo na fala. "Ruga” é um nome dado pelos agricultores/as às lagartas.

**Cigarrinhas são insetos da ordem Hemiptera, subordens Auchaenorryncha e Sternorryncha. Existem também vários tipos de cigarrinhas, sendo impossível saber de qual espécie os agricultores/as estão falando. 
Tabela 5. Comparação entre citações dos agricultores sobre os insetos (pragas e inimigos naturais) apresentados a eles pelas fotos e as considerações da literatura a respeito.

Citações das entrevistas com agricultores Informações da literatura consultada "Essa é a joaninha, a gente sabe, se virar a folha ela aparece”. "Ela Cicloneda sanguinea (Coleoptera: Coccinellidae)

come pulgão, ácaro também”.

Pertencente à família Coccinellidae, conhecidas por joaninhas. Corpo geralmente arredondado. Vivem geralmente sobre as plantas onde colocam seus ovos. Caminham e voam bem e caem no solo quando tocadas. Alimentan-se de pulgões e cochonilhas, existe entretanto, espécies fitófagas. Cycloneda sanguínea, de cor vermelha é predadora de pulgões” (Gallo et al, 2002).

“Este aqui eu já vi, parece aquele louva-deus mas não é, é este tem por aqui”.

Chrysoperla sp. (Neuroptera: Chrysopidae)

"Este aqui não é tipo de uma borboleta, é aquela que tem as asinhas Corpo delicado, tendo 10 a 15mm de comprimento, em geral de coloração verde. Colocam cerca assim, ela tem as asas bem branca”

predadores importantes alimentando-se de pulgões” (Gallo et al, 2002).

“Acho que deu em uns pé de erva meu, desse tipo aí dá umas Ácaro-vermelho - Oligonychus yothersi (Acari: Tetranychidae) teiarada”.

São ácaros de corpo globoso e com diversos pêlos simples distribuídos pelo corpo, sendo que a

"Isso não é aquele pulgão que dá nos citros nas laranjas que é só com binóculo para enxergar?”

extremidade posterior do corpo é mais afilada nos machos que nas fêmeas. Os adultos são de coloração avermelhada, com quatro pares de pernas e as larvas são amarelas, com apenas três pares de pernas. A reprodução é arrenótoca e as fêmeas depositam seus ovos nas folhas da erveira, protegendo-os com fios de seda que tecem. A colônia também se prolifera nas folhas protegida por estas teias. Atacam também abacateiro, mangueira, cafeeiro e nogueira (Penteado et al, 2000 e Gallo et al, 2002). Dois picos populacionais anuais são verificados nos meses de setembro e janeiro, coincidindo com os menores índices pluviométricos do ano e com a ocorrência de folhas maduras no campo, respectivamente (Alves et al, 2001). Com seus estiletes, perfuram as folhas, extravasando e sugando o conteúdo das células. Atacam em reboleiras e provocam o bronzeamento das folhas, prejudicando sua qualidade e podendo acarretar sua queda (Penteado et al, 2000 e Gallo et al, 2002). 
Tabela 5 Comparação entre citações dos agricultores sobre os insetos (pragas e inimigos naturais) apresentados a eles pelas fotos e as considerações da literatura a respeito.

\begin{abstract}
“Às vezes no mato a gente vê algum assim”. $\quad$ Lagarta-rabuda - Perigonia lusca (Lepidoptera: Sphingidae)
“A lagarta tem bastante”. S São lagartas que medem até 60mm de comprimento. Têm coloração verde-amarelada, com faixa

"Essa lagarta foi tipo aquela que encontrei três anos atrás assim meio dorsal longitudinal branca ou escura e áreas laterais com finas listras amareladas. Apresentam, grossinha igual esta”. no oitavo segmento abdominal, um prolongamento de coloração avermelhada. Empupam no ”Essa aparece bastante, só que aparecia mais quando era só erva- solo, na área de projeção da copa. Os adultos são acinzentados, com faixas escuras nas asas mate. A medida que você vai crescendo os pinheiro no meio, outras anteriores e com uma mancha amarela na asa posterior. Os adultos surgem principalmente na árvore vai eliminando isso aí”. primavera e são de hábito noturno e desenvolvem-se pelo menos duas gerações anuais durante a "Essa lagarta aqui sim, inclusive morreu uns pé lá, acho que por primavera e verão, podendo ser observada uma terceira no outono. Podem desfolhar causa disso aí”. completamente os ramos. Pela sua coloração críptica, geralmente só é notada tardiamente (Fernandez Diaz, 1997; Penteado et al, 2000; Alves et al, 2001 e Gallo et al, 2002).
\end{abstract}

“Esse aqui é quase tipo do fede-fede, a gente vê, mas é pouca coisa”. "Esse já vi, é o que fura o tronco, a lagarta dele né”.

Broca-da-erva-mate ou Corintiano - Hedypathes betulinus (Coleoptera: Cerambycidae) "Parece o corta galho, já assisti pela televisão, mas aqui na minha propriedade não tem”.

São besouros de coloração branca, com muitas manchas pretas nos élitros e protórax. Antenas

"Eu conheço este dali, mas aqui no Paraná não vi ainda, lá em Santa Catarina tinha”.

"Corintiano tem bastante”.

$25 \mathrm{~mm}$ de comprimento. As larvas são do tipo cerambiciforme, brancas e ápodas. Após o acasalamento, as fêmeas depositam os ovos isoladamente em fendas na casca dos ramos, sendo geralmente um ovo por galho, na região do colo (Fernandez Diaz, 1997; Penteado et al, 2000 e Gallo et al, 2002). Encontram-se presentes no campo o ano todo, com elevados níveis populacionais de outubro a maio, sendo o pico observado entre fevereiro e março (Soares, 1998). É a principal praga da erva-mate no Brasil.

As larvas, ao eclodirem, iniciam a abertura de galerias nos ramos, perfurando-os internamente. Por ocasião da perfuração dos ramos, prejudicam a circulação da seiva, além de destruírem os demais tecidos. Os ramos atacados secam, reduzindo a produção e depauperando a planta. Os adultos alimentam-se da casca dos ramos, não causando grandes prejuízos (Fernandez Diaz, 1997; Penteado et al, 2000 e Gallo et al, 2002). 
Tabela 5. Comparação entre citações dos agricultores sobre os insetos (pragas e inimigos naturais) apresentados a eles pelas fotos e as considerações da literatura a respeito

“Já vi desta vespa, não bem igual, mas já vi deste tipo por aí, a gente que mora na Vespa - Xanthopimpla stemator (Hymenoptera: Vespidae)

roça conhece os bichinho”.

Estes insetos vivem em sociedade, divididos em castas. Na fase adulta nutrem-se de

"Vespa a gente vê bastante".

"Essa tem por aí, é parecida com a vespinha que come o pulgão”. substâncias açucaradas como sucos, néctar, etc. Mas são também predadoras capturando e alimentando-se principalmente de lagartas de lepidópteros. Os parasitóides mais importantes estão dentro da ordem Hymenoptera (Gallo et al, 2002). 


\subsubsection{Relação estabelecida pelo agricultor com os insetos e a cultura da erva- mate}

Quanto mais se age de forma constante com o meio, começa-se a perceber detalhes dele que antes passavam desapercebidos. Nesse sentido, os agricultores estão constantemente relacionando-se com o ambiente em que vivem, pois trabalham nele, podendo ocorrer uma interação maior com determinados organismos, como os insetos, por exemplo.

Conforme Posey (1986), no caso dos índios Kayapó, os seus mitos relatam histórias de parentesco e afinidade com formigas, cupins e vespas, falando do comportamento destes e descrevendo como se deve agir com as formigas para defender as roças, num manejo do ecossistema. O conhecimento que possuem sobre as formigas nas roças faz com que dêem mais atenção aos detalhes que os cercam.

Assim, quanto aos entrevistados observou-se que a percepção deles em relação aos insetos é maior quando estes os afetam diretamente, como no caso dos insetos pragas, que causam danos em seus cultivos, como pode ser observado nas falas abaixo.

"O que prejudica mais é a lagarta que corta né, aquela lagartinha que prejudica mesmo a agricultura né. E a abelha é um bichinho que não estraga nada né, ela só junta o mel e a agüinha da flor né. Então o que dá estrago mesmo é a lagarta e a formiga cortadeira, essa é que estraga a lavoura de qualquer plantação" (Entrevistado Abelha)

“(...) mas, essa lagarta do corintiano, ela causa dano até razoável, porque ela seca muitos pés né, ela fura, quebra, lasca." (Entrevistado Fede-fede)

Perguntou-se aos agricultores se, dentre os insetos que conheciam todos eram maléficos ou se existiam insetos benéficos e, neste ponto, percebeu-se que a 
categorização de bom ou mau que fizeram está atrelada ao dano ou benefício que o inseto causou nas suas plantações. Também se percebeu que a classificação negativa atribuída aos insetos deriva do processo educacional, como por exemplo, as denominações de animal "nocivo” que é encontrada ainda hoje em cartilhas escolares.

“Haaaaa! Mais tem né, que nem este pulgão da soja ele prejudica né, e agora este outro aí da erva que eu fiquei conhecendo, o ácaro. Causam bastante dano”. (Entrevistado Borboleta)

"Eu acho que não, que não é todos que fazem mau, acho que uns até fazem bem, porque como a gente diz...eles vão se alimentando de uns para.. então derrepente pra um tipo de cultura ele é bom, outra prejudica, mas acho que não seriam assim nocivos todos ele”. (Entrevistada Joaninha)

"Eu acho que todos, todos não, maus a maioria acho que estraga”. (Entrevistado Pulgão)

Sabe-se que nos ecossistemas existem as cadeias alimentares e diferentes níveis de organização, conforme Odum (1988), e que, cada organismo tem seu inimigo natural. Assim sendo, no mundo dos insetos estas relações são bem evidentes e já estudadas em muitos grupos, sendo alguns exemplos apresentados nas páginas 16-20 deste trabalho. Representando possibilidades mais ecológicas e menos drásticas do que os produtos químicos no controle de pragas em agroecossistemas.

Os agricultores entrevistados sabem que muitos insetos passaram a se tornar pragas com o aumento no uso dos “venenos" e mesmo não sabendo o nome que a comunidade científica atribui às relações entre os indivíduos, sabem dessas relações que envolvem predação e controle biológico natural. Tal fato pode ser percebido nos discursos abaixo. 
“Acho que não né. Algumas joaninhas comem ácaros. Come também pulgão né“ (Entrevistado Fede-fede).

“Pois é, nós precisávamos ter a vespinha aqui para distrair muitos bichos, ao invés de passar veneno tinha que ter a vespinha para matar o bichinho que prejudica plantação, $e$ não tem“ (Entrevistado Lagarta).

“É um pouco, acho que a gente usa muito inseticida, herbicida e acaba até aquele e daí o mau aumenta e prejudica né” (Entrevistado Louva-deus).

“(...) o inseto ele começou assim de ter demais depois que começou usar o “veneno".Por que antes o inseto se comia um com o outro, se destruía né. Então agora o veneno destrói um tipo que destruía o outro. Mas eu pra mim inseto sempre dá prejuízo, se não é uma coisa é outra, porque coisa boa o inseto nunca ele pode se” (Entrevistado Vespa).

"Eu acho que tem muitos inseto que a gente acha que é prejudicial e que no final ele tem a parte benéfica, porque muitas vezes a gente só vê a ruindade deles, ma muitas vezes eles tem alguma coisa de bom também. Porque faz parte da natureza, tanto é que formiga demais a gente tem que combater né, mais tem certas formiguinhas aí que tão ali comendo. Aranha mesmo, eu não mato aranha porque eu acho que ela come muitos insetos”(Entrevistado Besouro). 
Segundo Mercante (2000), quanto mais um povo, um grupo utiliza-se de um determinado recurso, mais este recurso é alvo de estudo e maiores são as observações a respeito do assunto.

No caso da cultura da erva-mate, esta, apesar de estar presente na vida dos agricultores estudados, não é intensamente difundida e praticada, visto que, é considerada alternativa. Caso fosse um estudo com uma cultura agrícola principal, como o milho, por exemplo, que é um recurso que eles exploram com intensidade, talvez as observações dos agricultores/as sobre os aspectos que o envolvem, fossem mais elaboradas.

Assim sendo, os agricultores/as não percebem com tantos detalhes os elementos associados à erva-mate, como os insetos. E outro fator observado é que no município, as pragas da erva-mate não representaram grandes perdas aos erveiros e sendo assim eles não tiveram tanto contato com estes insetos.

O modo como o ambiente é percebido por estes agricultores/as influencia diretamente no modo como estes agem in locu. É explicitamente percebido que a relação homem-inseto seria mais expressiva, caso fosse uma cultura que sofresse danos relevantes pelos insetos, isto faria com que, os agricultores tivessem maior interesse ou necessidade de voltarem sua percepção para tais, pois a necessidade de um controle os instigaria a tanto.

"São de dar prejuízo sim, que nem do soja, do milho, os prejuízos são grandes. Não sei como se diz... aquela lagartinha do cartucho, essa ataca e dá prejuízo" (Entrevistado Borboleta).

Ao serem indagados sobre o uso ou não de inseticidas na cultura da erva-mate, nove, dos onze entrevistados disseram que nunca utilizaram nenhum produto químico na cultura. Isto é bom em termos ambientais, mas o fato é que, não utilizaram porque não foi necessário, não porque eles quiseram preservar o meio ambiente. Afinal precisam ter lucros e quando há problemas em outras culturas que dão lucros maiores, utiliza-se de 
inseticidas. Por isto que há a influência do fator econômico. Também, no sentido cultural, já é antropocentricamente determinado que inseto é mau e precisa ser eliminado e assim o fazem quando acham necessário.

Perguntou-se se estariam dispostos a utilizarem o controle biológico, criando inimigos naturais para combater as pragas, sendo que todos afirmaram que sim, mas com a ressalva de ter lucro. A preocupação maior não foi conservar o ambiente, apesar desta ter aparecido em alguns pronunciamentos aqui apresentados:

“A não! Se for preciso e a gente vê que dá o lucro a gente pode até criar e soltar e daí é um lucro pra gente também”(Entrevistado Abelha).

“Aqui quando foi plantada teve esse problema e aí passei um veneno, mas não me recordo mais qual era, tinha aí nas veterinárias. Passei só uma vez e hoje não tem mais isso. Eles me disseram que isso dá até que é novo, depois não dá mais” (Entrevistado Louva-deus).

"Só catei aquela vez as lagartas. Não, não usei nenhum produto químico e se ele fosse fácil de criar, claro que criaria. Que nem a vespinha do piolho, eu acho que não é difícil para criar aquilo lá” (Entrevistado Vespa).

“(...) Se era para o bem acho que sim né, porque no fumo assim até a gente coloca bem pouco veneno, até esse ano foi colocado um que o Rubi que sabe o nome.. .que nem fazia antigamente com a soja, com a própria ruga eles faziam....esse foi passado, mesmo atacando bastante a gente passava e resolvia “(Entrevistada Joaninha). 
“Eu teria. Teria por que não tem nada de gasto né. Você não está passando veneno, se intoxicando ou intoxicando a própria erva-mate e é um controle natural. Isso aí eu acho viável que nem a vespinha do trigo” (Entrevistado Besouro).

"Com certeza, acho que criaria por que no caso ele iria controlar as outras pragas né, então acho que sim." (Entrevistado Formiga).

"Não sei. Nunca notamos, não tem interesse por falta de lucro.” (Entrevistado Bicudo).

Buscando observar o conhecimento etnoentomológico do agricultor/a erveiro de Salto do Lontra chegou-se a conclusão de que a relação agricultor/a erveiro/inseto seria mais próxima se os insetos fossem um problema maior para eles na cultura do mate ou se estes lhes trouxessem benefícios de alguma forma.

Conforme Kellert (1996) os valores utilitários que o ser humano vê na natureza refletem-se em bens materiais, na satisfação das necessidades humanas, a medicina e a agricultura representam bem o campo de exploração utilitária da natureza nos últimos tempos. Quanto aos valores estéticos, estes refletem preferências individuais de cada pessoa e certos animais e paisagens refletem respostas das pessoas extremamente variadas dependendo da circunstância cultural e geográfica. Muitas das respostas estéticas das pessoas tendem a destacar grandes organismos, como mamíferos e aves, em contraste com a perspectiva ecológico-científica, que valoriza o estudo dos pequenos animais e microorganismos e enfatiza a interdependência entre as espécies em seus habitats.

Os insetos, por serem invertebrados de pequeno porte, apesar de algumas espécies apresentarem um tamanho maior, passam quase que despercebidos no dia-a-dia da maioria das pessoas, são estudados pela comunidade científica pela sua relevância 
ecológica e econômica, mas apenas são considerados pela comunidade em geral quando estão trazendo danos ao ser humano, nas suas plantações, no caso de agricultores.

Mesmo assim há um saber entre os agricultores/as, ainda que restrito sobre os insetos que habitam suas plantações e acredita-se que este saber não deva ser desprezado. Percebe-se que os agricultores/as citaram em suas falas vários tipos de insetos que percebem em sua rotina no campo e que necessariamente não estão associados à erva-mate, mas que podem estar em outros ambientes atuando como inimigos naturais ou mesmo pragas de outras culturas mais trabalhadas por eles, como o milho, feijão, soja e outras.

\subsection{Aspectos Ecológicos}

\subsubsection{Ervais nativos, ervais plantados e sistemas ecologicamente sustentáveis}

Atualmente, no estado do Paraná cerca de $64,4 \%$ dos produtores preservam ervais nativos e $35,6 \%$ realiza o adensamento e/ou plantio de ervais. Os ervais nativos concentram-se na Região Centro-Sul do Estado. A situação faz parecer que os produtores paranaenses estão preocupados com a conservação de áreas naturais (Andrade et al., 1999).

No município de Salto do Lontra e nos arredores não ocorre erva-mate nativa e a erva-mate existente é plantada. Os agricultores entrevistados atribuem o aumento de ervais plantados ao fator desmatamento e a uma exploração econômica mais intensa do produto nas últimas décadas. De fato, a exploração econômica aumentou em consequiência das pesquisas na indústria, aumentando a variabilidade de produtos feitos a partir da erva-mate. O desmatamento também é um fator que influenciou bastante a procura pelo plantio da erva-mate, como planta nativa da Mata Atlântica sofreu as conseqüências da exploração desta. Assim, os discursos abaixo reafirmam esta questão:

"É que aqui quase nem tinha nativa. Aqui no Salto do Lontra nativa era só alguns pés, era raro e então o pessoal passou 
porque aquela história, a doença (febre) da erva-mate, a promessa que ia valer dinheiro, ia valer bastante, nunca alguém tem uma bola de cristal para ver o que vai acontecer pra frente né“ (Entrevistado Besouro).

"Acho que é porque o pessoal começou a explorar ela mais economicamente e então passou a cultivar, aí facilitou a exploração" (Entrevistado Fede-fede).

"É que a maioria daquela erva-mate nativa foi destruída porque não tinha muita saída e derepente começou a ter saída e aí foram plantar de novo. Por que eu conhecia Palmeira das Missões no Rio Grande do Sul, que era ervamate nativa pura, pura erva e hoje vai lá ver não tem um pé de erva” (Entrevistado Lagarta).

A instabilidade econômica relacionada aos preços dos produtos agrícolas tradicionais como milho, soja, feijão e outros, também faz com que o agricultor esteja sempre buscando outras culturas como fonte de renda para o sustento de sua família. Neste sentido, a cultura do mate apresenta-se como uma alternativa. A reduzida fração de terra de muitos pequenos agricultores também os fazem optar por uma cultura ou outra.

Pode-se observar tal fato no depoimento de um agricultor:

“(..) é que a agricultura a um tempo atrás não ia muito bem por causa que defasou muito de preço de produto; outros com pouca terra também, então cada um procurou algo. Porco já ultimamente deu umas quedas então deixei do porco e resolvi plantar erva e frutas porque o porco há 8 anos atrás não tinha mais jeito porque criar dava prejuízo. Então começou lida com a erva, porque a erva, ela é um produto que quem 
pode plantar, quanto mais a frente os anos vão passando, mais ela vai se formando e se fosse plantar ela de 3 em 3 metros de distância, quando ela fecha isso ali, o cara tem meia quarta de erva formada, não 'sua' a moringa, pois ele vive muito bem tranqüilo só com a erva. Porque muitos dizem de plantar só de metro a erva, mas de metro viu, eu não acho muito vantagem por que os 'tarefero' viu, os dono do Barbaqua, eles não querem erva muito nova, porque a erva assim nativa ela é mais cara. Agora eu não sei se a nossa ali vai ter o mesmo preço, porque a nossa é orgânica, eu não uso produto químico. Não sei se vão pagar o mesmo.” (Entrevistado Vespa).

Nas décadas de 1960/1970 as fronteiras agrícolas do Paraná estavam se expandindo, ocorrendo a ocupação e novas frentes agrícolas em regiões novas, como a soja e o trigo no extremo Oeste e Sudoeste do estado, conforme afirma Costa (1995). A este fato pode-se atribuir a destruição das florestas nativas, pois assim abriram-se as fronteiras agrícolas nos anos 1960/1970 e tal fato, obviamente diminuiu ou extingui em alguns locais de menor densidade a espécie da erva-mate. Por isto também, mais tarde, foi preciso plantá-la, como é o caso do município de Salto do Lontra e região.

A agricultura moderna e tecnológica contribuiu muito para o estabelecimento das monoculturas e conseqüentemente para o aumento dos problemas ecológicos e socioeconômicos. Assim, a erva-mate também foi prejudicada neste contexto.

No entanto, a nova corrente de agricultura, chamada por Dunlap e Beus (1990) de alternativa, e por Leff (2002) e Guzmán (2002) de agroecológica está baseadas em valores culturais distintos e com pressupostos sociais. Acredita-se que a cultura da ervamate possa ser encarada dentro desta perspectiva pelos agricultores familiares no sentido de contribuir para aumentar sua renda, ao mesmo tempo em que, ocorra um manejo adequado deste recurso natural. 
Conforme Guzmán (2002) a agroecologia apresenta sua crítica mais forte à agricultura convencional quando a mesma ignora as pessoas vinculadas ao manejo dos recursos naturais. $\mathrm{O}$ autor coloca que os pesquisadores precisam dialogar com os pesquisados para que as ações levem a uma transformação crítica e as populações rurais se sintam valorizadas e potentes para resolver seus problemas locais. Nesse sentido concorda-se com o autor, afinal os produtores de erva-mate enfrentam problemas ocasionados pelos erros da agricultura convencional há muito tempo e uma saída de forma sustentável seria o intercâmbio dos saberes entre as pessoas envolvidas com a cultura, a troca de informações e ações conjuntas para que o produto deles melhore a qualidade e seja mais bem aceito no mercado.

Todavia, os agricultores têm consciência de que a erva nativa é mais valorizada na hora da venda e sabem que existem possibilidades de melhorar o erval e tornar o ambiente o mais semelhante possível das condições naturais da planta. $\mathrm{Na}$ fala de Besouro isto fica claro.

“(...) e outra coisa é o seguinte: eles dão mais valor pra erva nativa porque dá um sabor melhor e essas erva plantada ali (...) por isso que eu digo que vale a pena ter bastante árvore no meio. Eu tinha um pedaço lá que muitas vezes os cara levavam e eu dizia pros cortador olha isso aí é que nem erva nativa, é erva boa. É porque tinha bastante árvore associada no meio e então ela volta a um estilo de erva nativa né. O grande passo da erva- mate é a araucária, o pinheiro nosso brasileiro, mesmo no meio, uns pé meio ralo, ele eu acho que elimina muitas doença. Essa ampola que enrola a folha com os bichinho que fica casinha dentro e então ela fica mais o natural dela”.

A erva-mate quando consorciada a outras espécies florestais e mesmo agrícolas diminui a incidência dos problemas fitossanitários. O sistema de cultivo em monoculturas, em geral, tende a apresentarem problemas maiores com pragas que 
atacam as culturas, ao contrário do sistema de plantios consorciados que ajudam a oferecer refúgios biológicos a estas espécies. Tal fato é observado pelo agricultor, conforme o próximo registro:

“(...) eu gosto da erva-mate, eu tenho uns pedaços onde tem uns pinheiros no meio, uns coqueiros, alguns pés de fruta do mato, guabiroba é bom ter porque aí sempre senta passarinho, a gente sempre vê lá papagaio destes grandes grudado no coqueiro comendo frutinha, então acho que só a erva-mate não é interessante. Se tiver alguma espécie de fruteira no meio é muito, muito bom por que é um reflorestamento, mantém o ambiente, tem passarinho $e$ tudo"(Entrevistado Besouro).

Mesmo que a prioridade seja obter um lucro considerável da cultura, há uma preocupação ou uma sensibilidade para com a conservação do ambiente no agroecossistema da erva-mate. Tal fato advém de uma correlação com a erva-mate nativa, caracterizada por estar associada, em ambiente natural a outras espécies da Mata Atlântica, como as araucárias, por exemplo. Essa relação é percebida quando ao agricultores/as falam que a erva-mate convive bem com determinadas plantas associadas, na tentativa de tornar a erva plantada o mais semelhante possível com a erva nativa, em aspectos como sabor e qualidade.

“(...) é geralmente a erva nativa dá debaixo dos pinheiro e então ela não pega muito sol e é por isso que ela é mais saborosa do que esta outra que está no relento do sol. Eu se fosse plantar mais erva-mate e até onde está meio rala, vou plantar no meio alguns pinheiros, só que o pinheiro não se dá onde tem pedras né, mais alguns pés de pinheiro nem que não dê madeira, mas eles impedem muitas doenças na erva-mate. 
E de preferência plantar consorciada, se tiver algum mato ou árvore deixe., os galhos ficam por cima da erva e vai desbastando os galhos próximos a ela, a erva não se incomoda. Ela não gosta assim de um sinamão ou aquelas plantas que matam o que tiver embaixo né. Então uns coqueiros, umas frutas vai bem, faz bem até para os passarinhos né" (Entrevistado Besouro).

A conservação da biodiversidade e o manejo sustentável são assuntos em pauta nas últimas décadas, as populações humanas têm ocupado quase todos os ecossistemas terrestres como caçadores, pescadores, agricultores e extratores. A busca por sistemas mais sustentáveis de exploração dos recursos naturais também utiliza como uma das estratégias, os sistemas agroflorestais, em que o ser humano retira seus produtos e ao mesmo tempo conserva as espécies locais, tais processos podem ser observados em várias sociedades tradicionais de todo o mundo (Primack \& Rodrigues, 2001).

Segundo Medrado (2000), nos últimos anos tem aumentado significativamente as áreas de ervais plantados e o sistema predominante tem sido a exploração em consórcio com culturas anuais de inverno (trigo, aveia e coberturas verdes) e de verão (soja, milho e feijão).

É interessante notar o conhecimento do agricultor erveiro sobre o sistema de manejo da cultura. Sabe que a planta oferece um produto preferido pelos compradores quando, em estado nativo e sombreada por outras árvores, conforme coloca Mazuchowski (2000) corroborando com as falas dos agricultores/as:

"Ela é melhor, a erva nativa, do mato, pra chimarrão ela é mais gostosa, a erva plantada, ela dá um tipo...um amargo a mais... a gente fazia erva né...” (Entrevistado Pulgão).

“(...) então o corte mesmo da erva tem que ser de dois em dois ano e de um e um ano ela fica amarguenta por causa do 
broto. A maior parte da erva que a gente compra por aí é tudo de broto que fica amarga e aí é tudo a força da raíz do pé da água fica no broto. E de 2 em 2 ano ela vai criando galho, ficando madeira e fica mais boa né” (Entrevistado Abelha).

Também, o sistema de consorciamento possibilita que o agricultor tenha outras fontes de renda, e do ponto de vista ecológico, tenha menos problemas com pragas, já que estas terão mais inimigos naturais, por causa da maior diversidade da flora local, bem como a possibilidade de recuperação de terras marginais degradadas.

Do ponto de vista ambiental, a cultura da erva-mate em ervais plantados constituindo sistemas agroflorestais, apresenta-se plenamente viável. Baggio et al. (1982) e Montoya \& Mazuchowski (1994) descrevem os sistemas agroflorestais mais utilizados na região Sul do Brasil e destacam a importância do sistema agroflorestal da erva-mate, dado o seu potencial socioeconômico e ambiental e a atenção dada por parte de técnicos e pesquisadores para elaborar estudos que fortaleçam seu desenvolvimento de forma sustentável.

Devido à diversidade dos sistemas agroflorestais, como: unidades produtivas pequenas e diversificadas, inclusão de plantações de longo prazo no meio de outras de curto prazo, espaçamentos diferentes, dificuldades de acompanhar sistematicamente os sistemas que incluem variáveis e interações numerosas, e as informações econômicas escassas, estes sistemas são pouco difundidos. Entretanto, os autores (op. cit.) concluem que, mesmo havendo falta de informação sobre o sistema, as propriedades podem beneficiar-se da erva-mate associada com cultivos anuais.

Nos ervais visitados em Salto do Lontra o sistema agroflorestal foi observado apenas em três propriedades. Havia outras culturas como milho e mandioca e ainda araucárias plantadas entre as erveiras. Enquanto nos outros ervais visitados não havia este tipo de consorciamento, estando estes plantados a pleno sol. 


\subsubsection{Diversidade da entomofauna em dois ervais plantados no município de Salto do Lontra}

Outro aspecto, em relação à biodiversidade do agroecossistema da erva-mate foi observado no município de Salto do Lontra. Nas coletas entomológicas realizadas nos em dois ervais locais foi possível observar uma ampla diversidade de famílias de insetos. No erval 01 foram identificadas 35 famílias de insetos e no erval 02 tivemos 33 famílias. Para expressar melhor a diversidade da entomofauna local foi aplicado o índice de diversidade (H'), o qual pode ser observado na Tabela 4.

Observa-se na tabela acima que o índice de diversidade obtido foi de 1,32 para o erval 01 e 1,28 para o erval 02. Mesmo o erval 01 estando em melhores condições quanto à limpeza e manejo, tendo um capão de mato próximo a ele, não foi discrepante a diversidade de sua entomofauna associada em relação ao erval 02 que se encontra em estado de abandono, e está em processo de sucessão ecológica. Segundo Fernandez Diaz et al., (2000) ao surgirem novas associações de erva-mate com espécies herbácias, estas proporcionam refúgios a espécies de insetos que cumprem a função de controlar as populações de insetos prejudiciais. Acredita-se que a diversidade da entomofauna no erval 01 tem influência da mata próxima e a do erval 02 tem influência das plantas associadas ao erval que está abandonado.

Neste ponto foi observado que a entomofauna do erval é maior ou menor de acordo com as associações deste erval com outras plantas. E, que uma alta diversidade de entomofauna pode indicar um estágio de equilíbrio biológico, demonstrando que, quando há interesse na produção, um sistema de manejo pode funcionar sem problemas com pragas. 
Tabela 4. Famílias de insetos coletadas nos dois ervais plantados no município de Salto do Lontra, PR. N= número de famílias de insetos, $\mathrm{H}^{\prime}=$ índice de diversidade de Shannon

\begin{tabular}{lcclcc}
\hline ERVAL 01 & Ocorrência & O\% & ERVAL 02 & Ocorrência & O\% \\
\hline Alleculidae & 2 & 22,30 & Alleculidae & 1 & 0,93 \\
Apidae & 3 & 3,45 & Anthocoridae & 1 & 0,93 \\
Aradidae & 1 & 1,15 & Apidae & 5 & 4,67 \\
Bastrichidae & 1 & 1,15 & Blatellidae & 2 & 1,87 \\
Cantharidae & 8 & 9,20 & Braconidae & 1 & 0,93 \\
Carabidae & 1 & 1,15 & Calchidoidae & 2 & 1,87 \\
Chelisochidae & 1 & 1,15 & Cantharidae & 18 & 16,82 \\
Cicadellidae & 8 & 9,20 & Carabidae & 2 & 1,87 \\
Cicadidae & 1 & 1,15 & Cicadellidae & 2 & 1,87 \\
Coccinellidae & 1 & 1,15 & Coccinellidae & 10 & 9,35 \\
Crysomelidae & 3 & 3,45 & Coreidae & 2 & 1,87 \\
Curculionidae & 1 & 1,15 & Dictyopharidae & 2 & 1,87 \\
Erothilidae & 1 & 1,15 & Dolichopodydae & 1 & 0,93 \\
Formicidae & 5 & 5,75 & Formicidae & 18 & 16,82 \\
Halictidae & 1 & 1,15 & Halictidae & 2 & 1,87 \\
Lygaeidae & 1 & 1,15 & Lygaeidae & 3 & 2,80 \\
Melirydae & 14 & 16,09 & Melyridae & 2 & 1,87 \\
Membracidae & 9 & 10,34 & Membracidae & 3 & 2,80 \\
Miridae & 4 & 4,60 & Miridae & 3 & 2,80 \\
Mordellidae & 2 & 2,30 & Mordelidae & 4 & 3,74 \\
Mutillidae & 1 & 1,15 & Mutillidae & 1 & 0,93 \\
Pentatomidae & 4 & 4,60 & Nitidulidae & 1 & 0,93 \\
Psyllidae & 1 & 1,15 & Pentatomidae & 3 & 2,80 \\
Rhopalidae & 1 & 1,15 & Psilidae & 1 & 0,93 \\
Scarabaeidae & 2 & 2,30 & Reduviidae & 2 & 1,87 \\
Scutelleridae & 2 & 2,30 & Scarabaeidae & 2 & 1,87 \\
Silphidae & 1 & 1,15 & Scutelleridae & 2 & 1,87 \\
Tachinidae & 1 & 1,15 & Staphylinidae & 5 & 4,67 \\
Tenebrionidae & 1 & 1,15 & Tachinidae & 3 & 2,80 \\
Tephritidae & 2 & 2,30 & Vespidae & 3 & 2,80 \\
Tettigoniidae & 1 & 1,15 & & & \\
Vespidae & 2 & 2,30 & & 33 & 100 \\
N & 35 & 100 & & & 1,28 \\
H' & & 1,32 & & & \\
\hline & & & & & \\
\hline
\end{tabular}




\subsection{Aspectos Socioeconômicos}

\subsubsection{O município de Salto do Lontra e a cultura da erva-mate: como tudo começou}

O início da ocupação do município data de 1951 e, segundo dados obtidos em documentos municipais e principalmente em conversas informais, as primeiras atividades dos agricultores foram a criação de suínos e o plantio de feijão. Depois, com a revolução agrícola das décadas de 1960/1970 passou-se a plantar outras culturas como milho e soja.

A cultura da erva-mate é relativamente nova no município, nenhum dos entrevistados começou a plantar erva-mate há mais de dez anos. A forma como os agricultores começaram a trabalhar com a cultura não diferiu muito entre os entrevistados. Alguns trabalhavam com a cultura antes mesmo de virem morar no município de Salto do Lontra e foram influenciados por suas tradições familiares passadas de pai para filho, vindas de outros locais do Estado do Paraná ou mesmo de outros Estados. Isto foi observado nos depoimentos seguintes:

"Eu afinal me criei em Pato Branco e então lá, meu pai trabalhava com a erva nativa, todo ano a gente tirava lá, canchava, feito aqueles carijo e vendia pro soque" (Entrevistado Louva-deus).

“Olha... isso aí viu, a gente sabia que lá em Santa Catarina nós já trabalhávamos com ela e lá era assim aquela do mato né”. “...é, e sempre dava um lucrinho mais ou menos né. Então quando vim pra cá que larguei de trabalhar com os porco, então resolvi de plantar a erva” (Entrevistado Vespa). 
Porém, chamou a atenção o fato de os entrevistados mencionarem que houve uma espécie de incentivo da Emater local divulgando que a cultura traria lucros:

”A gente começou através da Emater né. O pessoal começou a falar e a gente resolveu plantar um pouco..." (Entrevistado Fede-fede).

"Foi tirado a semente, o Valdir da Emater trouxe a semente e a muda foi produzida aqui. Comecei há uns 5 a 6 anos...” (Entrevistado Bicudo).

De fato, no ano de 1997, a Emater de Salto do Lontra iniciou um trabalho com a cultura da erva-mate. Segundo os relatos do técnico local, foi realizado um curso de um ano, dividido em várias etapas, sobre o plantio e cultivo de mudas de erva-mate. O curso agregou cerca de 30 participantes. As primeiras sementes da planta vieram de Venâncio Ayres, no Rio Grande do Sul, e deste grupo de pessoas que se interessaram pelo curso, saíram grupos para a formação de 24 viveiros espalhados pelas comunidades rurais. No entanto, estes grupos não perduraram, apenas dois grupos fizeram o viveiro e começaram a cultivar as mudas. Atualmente, estes viveiros não existem mais, os donos desistiram do negócio e nem moram mais no município de Salto do Lontra. Segundo relatos dos técnicos da Secretaria de Agricultura Municipal e da Emater local, estes agricultores não alcançaram os lucros desejados com os viveiros e tiveram que abandoná-los; pois a oferta de mudas foi muito maior que a procura por elas.

"Nós começamos com a erva-mate porque começaram incentivar um pouco a plantar a erva-mate e então aí surgiu a oportunidade e nós tinhamos um viveirista aqui bem pertinho que fazia muda e aí a gente se empolgou e plantou um pouquinho" (Entrevistado Lagarta). 
"Nós começamos meio que por acaso, porque tinha um plantador de erva.. .e daí passando lá onde ele fazia as mudas me interessei pelo plantio e daí vi os canteiros bonitos e também porque ouvi falar que podia ser uma cultura que fosse trazerbenefício, renda pra gente"(Entrevistado Formiga).

Fica evidente pela fala dos agricultores que o programa da Emater em desenvolver viveiros locais de mudas de erva-mate foi um fator importante na época, para que se iniciassem novos cultivos plantados de erva-mate no município.

Outros aspectos levantados pelos produtores que explicariam seu interesse pela cultura é em relação ao aproveitamento da terra, o reflorestamento e a alternativa de fonte de renda que a cultura representa, conforme é colocado nas falas:

“(...) eu até já cheguei até plantar alguns lugarzinhos mecanizados, mas antigamente não se mexia com plantio direto e então o mecanizado tinha algumas pedras e dava muito problema de quebra de máquina, arado... .então a gente assim até onde tinha alguma veradinha que não era própria para o mecanizado a gente plantou erva-mate" (Entrevistado Besouro).

"Meu interesse em plantar a erva-mate lá foi porque eu reflorestei todo meu terreno e como eu plantei eucalipto, pinus e erva- japão então eu resolvi de plantar erva-mate também porque já tinha construído uns 4 a 5 pés de erva velha que dá média de 300 a 400Kg e daí depois plantei uns 6 ou 7 pé mas sem sorte não pegou e daí eu continuei depois resolvi e plantei 
mais uns 250 pé, só que tudo não pega, sempre morre.” (Entrevistado Abelha).

"Isso aí antigamente existia uma certa influência que a ervamate dava dinheiro ...vamos dizer aí um pé de erva, o preço que era, dava no mínimo cinqüenta centavos a $R \$ 1,50$ o pé de 4 a 5 anos de idade ela produzia para dar isso e hoje não compensa ... Depois que eu vim morar aqui no Salto eu não lutava com erva-mate, mas com o tempo, com aquela influência que existia, então comecei a plantar e achava que podia uma hora a gente ter uma renda mais fácil né” (Entrevistado Louva-deus).

“(..) por que a erva é um produto que depois de formada já há 8 a 10 anos pra frente, uma família já digo de 3 ou 4 que vive na casa, com 2 alqueires pode viver muito bem só com a erva. Se quer cortar de 2 em 2 anos, ou então cortar metade agora e a outra metade em outro ano. Então eu acho que pra mim a erva, ela tem é significativa, porque um dia vai ter uma renda”(Entrevistado Vespa).

\subsubsection{A erva-mate como alternativa de renda}

Para os agricultores entrevistados, a erva-mate é uma cultura secundária, e que não necessita de muito cuidado. Portanto, não é uma fonte de renda primária para a família na atual situação.

A região é caracterizada pelo cultivo de soja, milho, feijão, fumo, trigo, mandioca e outras atividades como a pecuária, a suinocultura e a avicultura. Estas atividades são citadas pelos agricultores entrevistados como sua fonte de renda mais 
importante. No entanto, percebe-se que há uma coerência de que a cultura pode representar uma fonte de renda alternativa, conforme eles mesmos dizem:

“(..) é um dinheirinho extra que entra, mas não é algo que a gente tenha que se dedicar, acho que não vale a pena, hoje não” (Entrevistada Joaninha).

“(..) a erva era um complemento”(Entrevistado Besouro).

O principal problema levantado em relação à cultura para que ela represente uma fonte de renda real e constante, é a difícil comercialização do produto pelos agricultores na região. Quando tocavam neste ponto sentia-se a desilusão e desânimo deles em relação ao comércio da erva-mate, confirmado nos pronunciamentos dos entrevistados:

(...) o comércio aqui não tem...tem Cascavel, Realeza, mas esses soques aí não pagam a pena.”

(Entrevistado Borboleta).

“(..) porque não tem saída pra gente vender, fazer uma colheita para fazer o dinheiro e então por enquanto não tenho renda" (Entrevistado Abelha).

Diante de tal fato, observa-se que a cultura da erva-mate no município é secundária porque não há uma forma de saída do produto para a comercialização. As cidades maiores e mais próximas ao município são Cascavel e Francisco Beltrão e as empresas de ervateiras não se disponibilizam a recolher pouca quantidade do produto, pois não é viável à elas economicamente.

Durante o trabalho, alguns agricultores e mesmo os técnicos da Secretaria da Agricultura Municipal falaram sobre um soque (ou local de beneficiamento da matéria prima erva-mate) que havia no município, o qual foi destruído por um incêndio. Sendo 
assim, os produtores de Salto do Lontra ficaram desamparados na hora da comercialização.

Nesse sentido, dentro de um plano de reestruturação e manejo da cultura da erva-mate no município, haveria a necessidade de implementação de um soque local, ou mesmo em uma cidade mais próxima, como Dois Vizinhos ou Nova Prata, por exemplo, pois assim beneficiaria não somente os produtores de Salto do Lontra, bem como os de outras cidades vizinhas que enfrentam problemas semelhantes.

\subsubsection{A assistência técnica no campo e a organização dos agricultores}

"Quem esclarecia assim digamos para a gente cuidar um pouco era o próprio Clodoaldo né, que ele fornecia as muda pra gente e daí ele que dizia vocês têm que fazer assim $e$ assim... mas de fora não tinha ninguém" (Entrevistada Joaninha).

“Nós não tínhamos orientação nenhuma para o plantio, que distância entre linhas, entre pés, nada disso, nós plantamos assim a rumo" (Entrevistado Lagarta).

"Recebi até fazer a muda. Depois que plantou, ninguém mais apareceu pra ensinar nada" (Entrevistado Bicudo).

A atuação dos técnicos na extensão rural tem sido caracterizada pelo autoritarismo, a pretensão do domínio do saber, de receitas prontas e descontextualizadas da realidade daquele produtor, que é considerado muitas vezes ignorante. O grande ponto é que os técnicos são considerados pessoas de fora, que vem para dar ordens, dizer como se faz, ensinar. E não há um ponto em que se compartilhe o conhecimento e se faça ouvidos às necessidades reais do agricultor, em que se possa 
criar uma identidade, porque ela está distanciada pelo domínio do saber técnico e o total desprezo ao senso comum.

Freire (1971) faz uma crítica ao trabalho do extensionista que impõe o conhecimento técnico ao agricultor argumentando que o agricultor tem uma outra percepção do seu mundo diferente daquela aprendida na academia e que ninguém aprende nada através da domesticação. Segundo o autor (op.cit., p.26):

“Conhecer, na dimensão humana que aqui nos interessa, qualquer que seja o nível em que se dê não é o ato através do qual um sujeito, transformado em objeto, recebe, dócil e passivamente, os conteúdos que outro lhe dá ou impõe. O conhecimento pelo contrário, exige uma presença curiosa do sujeito em face do mundo. Requer sua ação transformadora sobre a realidade”.

A respeito disso, Geertz (1999) faz uma crítica às desqualificações de outros saberes por aqueles que crêem fundamentados na ciência oficial de que o conhecimento é unilateral. Os agricultores conseguem trocar informações entre eles porque se identificam culturalmente, o que os difere na relação com os técnicos.

No contexto estudado observou-se que a atuação dos técnicos restringiu-se ao meio agrícola. Segundo Carvalho (2001), mesmo que a proposta do trabalho de extensão rural seja de uma transição ambiental, uma mudança orientando a ecologização das práticas agrícolas no manejo dos agroecossistemas, necessita-se expandir os ideários ambientais aliando-se a um conjunto de práticas sociais e culturais no mundo rural, não necessariamente agrícola. A produção não pode ser o único fim, ela precisa gerar uma qualidade de vida ao homem do campo.

Ouvir outros saberes, outras verdades, experiências de solidariedade e produção não capitalista que estão dando certo mundo afora, no mundo considerado atrasado pela modernidade ocidental, faz-se necessário para que criemos e esperemos um novo mundo, emancipado e feliz (Santos, 2003) ${ }^{10}$.

\footnotetext{
${ }^{10}$ Boaventura de Sousa Santos em conferência proferida no congresso de Sociologia da UNICAMP no dia 08/09/2003.
} 
Traçando um paralelo com Leff (2002) quando defende a perspectiva agroecológica para a agricultura, assume-se que a consolidação deste processo depende do fortalecimento da capacidade organizativa das próprias comunidades, para desenvolver alternativas produtivas que permitam melhorar suas condições de vida e aproveitar seus recursos de forma sustentável.

Dentre o conjunto de práticas para a melhoria da qualidade de vida dos agricultores pode estar o sistema de cooperativismo.

Os agricultores erveiros de Salto do Lontra não possuem uma cooperativa que se dedique a auxiliá-los com a cultura do mate e este tipo de sistema é pouco difundido entre os erveiros, conforme já mencionado na p.24. Eles têm as mesmas dificuldades enfrentadas pelos produtores do Rio Grande do Sul e Santa Catarina, a respeito, principalmente, da comercialização de seu produto. Reclamam do preço e da falta de acesso aos compradores, que não se interessam por pequenas quantidades, como eles próprios reconhecem:

“(...) também não adianta o agricultor que vai plantar lá um pedacinho de uns 200, 300 ,500 pé de erva-mate a não ser que tenha outros vizinho que plante se não na hora de vender ninguém quer nem dado. Aqui acontece muito isso, o agricultor tem pouquinha coisa plantada e aí fica difícil de vender e ai os caras ficam uns anos e terminam tirando fora a erva-mate “ (Entrevistado Besouro).

A saída encontrada pelos produtores do Rio Grande do Sul, o caminho das organizações através de associações, sindicatos e cooperativas fez com que eles não abandonassem a cultura, pois através da união dos pequenos produtores eles conseguiram formar um conjunto maior que se tornou competitivo no mercado.

Mas, para que o conjunto cresça é preciso estabelecer parcerias com os sindicatos, associações e universidades. O conjunto crescendo, a divisão precisará ser, pautada em alguns princípios e sobre estes cabe salientar o que diz Bitencourt (2000, 
p.194) sobre as cooperativas, colocando que um dos princípios deste é que "ele deve ser constituído por muitas pequenas cooperativas, dirigidas, controladas e a serviço de muitos” e não em grandes cooperativas controladas e a serviço de poucos como ocorreu na maioria dos casos no Brasil.

Essas grandes cooperativas mistas já existem na região e nos moldes que se apresentam não abrigam as necessidades dos produtores de erva-mate, pois privilegiam a comercialização de outros produtos agrícolas como soja e milho, por exemplo, que são cultivadas em sua maioria, pelos grandes agricultores.

As organizações sindicais e associações de produtores familiares têm obtido melhorias nas políticas públicas como o PRONAF (Programa Nacional de Fortalecimento da Agricultura Familiar) e pequenos avanços na reforma agrária. Porém, as políticas de crédito agrícola apresentam muitas dificuldades à maioria destes agricultores. Na busca de alternativas de crédito à pequenos agricultores, organizaram-se associações de agricultores familiares criando o Sistema Cresol de Cooperativas de Crédito Rural.

A experiência no Sul do Brasil com este sistema de crédito ao pequeno produtor tem dado certo. Visando a solução de um conjunto de problemas, o sistema Cresol é articulado e vinculado a diversas organizações que têm como eixo de atuação a promoção da agricultura familiar. Neste sentido, articula-se com associações, pequenas agroindústrias, casas familiares rurais, escolas comunitárias agrícolas, cooperativas, organizações não-governamentais e sindicatos rurais (Bittencourt, 2000).

As políticas econômicas contemporâneas não deixam muitas alternativas aos pequenos trabalhadores e isto tem feito com que o cooperativismo e outras formas de produção solidária venham surgindo na tecitura social brasileira.

Singer (2002) aponta o caminho da Economia Solidária como alternativa de melhoria das condições de vida dos pequenos. Para o autor, a empresa solidária não separa trabalho a posse dos meios de produção, ao contrário da base capitalista. A empresa solidária pertence aos trabalhadores que nela trabalham, a empresa capitalista pertence aos investidores. A finalidade básica da empresa solidária não é maximizar o 
lucro, mas a quantidade e a qualidade do trabalho. As "sobras" da cooperativa são destinadas conforme a decisão dos trabalhadores.

Mesmo parecendo utópico, estas formas de organização existem no Brasil e também em outros países e se apresentam como formas alternativas de produção emancipadoras, as quais segundo Santos (2002), estão baseadas em valores e princípios não capitalistas. O cooperativismo considera que o mercado promove um dos seus valores centrais, a autonomia das iniciativas coletivas e os objetivos de descentralização e eficiência econômica que não são acolhidos pelos sistemas econômicos centralizados.

Os caminhos da cultura do mate no Sul do Brasil, talvez encontrem no cooperativismo uma saída promissora frente aos problemas enfrentados pelo do setor ervateiro nos últimos anos. A organização dos produtores pode levá-los a valorizar mais a cultura como uma fonte de renda alternativa para suas famílias.

\subsubsection{Os produtos derivados da erva-mate}

Segundo os agricultores entrevistados, o principal uso da erva-mate, feito por eles, é a bebida do chimarrão, o qual é característico da região Sul do Brasil e é tradicionalmente consumido pelas gerações que se seguem.

De fato, o consumo da erva-mate no Brasil ainda é, na maior parte, em forma de chimarrão, cerca de 97\% da produção nacional (Tormen, 1995).

Porém, segundo Andrade et al (1999) a erva-mate é rica em alcalóides como a cafeína, taninos como ácido fólico, sais minerais, ferro, fósforo e alumínio, além de glicídios, sacarinas, lipídios e outros. Assim, ela poderia ser considerada um alimento quase completo, contento quase todos os nutrientes necessários ao nosso organismo.

O botânico Renato Kaspari citado pelo Anuário Brasileiro da Erva-mate (1999) salienta que a erva-mate destaca-se por sua atividade estimulante física e mental atuando beneficamente sobre os nervos e eliminando a fadiga. Uma vantagem da erva-mate sobre o café, por exemplo, é que ela tem uma ação estimulante mais prolongada e não deixa efeitos colaterais como a irritabilidade e a insônia.

Além do chimarrão, foram citadas pelos entrevistados, outras utilidades do produto, como tinta, chá, cola, tererê, madeira, medicamentos e exportação, as quais 
retirando a madeira e a exportação, estão relacionadas na tabela de industrialização abaixo. O que isto demonstra, é que o conhecimento deles neste aspecto de usos alternativos da erva-mate é restrito frente às inúmeras possibilidades apresentadas na Figura 4.

O desconhecimento do produtor, conforme observa-se na fala abaixo, sobre as derivações do produto que ele planta na sua propriedade, pode deixá-lo alienado frente à situações de mercado. Neste ponto, se a assistência técnica fosse eficiente e mais comprometida, poderia mostrar, de forma simples estas informações ao produtor e auxiliá-lo em suas dificuldades.

\section{"A gente nunca teve uma orientação, talvez a gente tinha plantado mais erva“ (Entrevistado Lagarta).}

Segundo os dados da Emater (1995) a erva-mate tem aplicações industriais para usos alternativos que podem ser observados no quadro a seguir:

\begin{tabular}{|c|c|c|}
\hline Aplicação Industrial & Sub-Produtos Comerciais & Forma de Consumo \\
\hline \multirow[t]{2}{*}{ Bebidas } & $\begin{array}{l}\text { Chimarrão, tererê, chá-mate: queimado, } \\
\text { verde/cozido, solúvel }\end{array}$ & Infusão quente ou fria \\
\hline & Refrigerantes, sucos, cerveja, vinho & Extrato de folhas diluído \\
\hline \multirow[b]{2}{*}{ Insumos de alimentos } & $\begin{array}{l}\text { corante natural } \\
\text { conservante alimentar }\end{array}$ & \multirow[b]{2}{*}{ Clorofila e óleo essencial } \\
\hline & $\begin{array}{l}\text { sorvete } \\
\text { balas, bombons e caramelos } \\
\text { chicletes e gomas }\end{array}$ & \\
\hline \multirow{2}{*}{ Medicamentos } & estimulante do sistema nervoso central & $\begin{array}{c}\text { Extrato de cafeína e } \\
\text { teobromina }\end{array}$ \\
\hline & $\begin{array}{lccc}\text { compostos para } & \text { tratamento } & \text { de } \\
\text { hipertensão, bronquite e pneumonia } & \end{array}$ & Extratos de flavonóides \\
\hline \multirow[t]{2}{*}{ Higiene Geral } & $\begin{array}{l}\text { bactericida e antioxidante hospitalar e } \\
\text { doméstico } \\
\text { esterilizante } \\
\text { emulsificante }\end{array}$ & \multirow[t]{2}{*}{$\begin{array}{c}\text { Extrato de saponinas e óleo } \\
\text { essencial }\end{array}$} \\
\hline & $\begin{array}{l}\text { tratamento de esgoto } \\
\text { reciclagem de lixo urbano }\end{array}$ & \\
\hline Produtos de uso pessoal & $\begin{array}{l}\text { Perfumes, desodorantes, cosméticos, } \\
\text { sabonetes }\end{array}$ & $\begin{array}{l}\text { Extrato de folhas seletivo e } \\
\text { clorofila }\end{array}$ \\
\hline
\end{tabular}

Figura 2- Aplicações industriais e usos alternativos para a erva-mate.

Fonte: EMATER - Paraná, 1995. 
No entanto, estas informações acerca das propriedades da erva-mate são desconhecidas pela maioria das pessoas e percebeu-se que isto não é diferente entre os entrevistados, pois estes “ouviram falar”, mas a informação está distante, é algo ainda desconhecido por eles. As informações sobre os produtos derivados da cultura não chegam a todos os produtores e as que chegam, são através dos meios de comunicação como a televisão.

\footnotetext{
"Mas existe para vários tipos, eu já escutei uma reportagem, é para várias utilidades a erva"(Entrevistada Joaninha).
}

\subsubsection{O trabalho familiar no campo}

O trabalho no campo, o cuidado em geral, como serviço de capina e roçada é feito na maioria das vezes pela própria família, os pais e os filhos, e, quando necessário, por peões contratados temporariamente. O serviço da poda é normalmente atribuído aos empregados da empresa que compra a erva. A agricultura praticada é predominantemente no sistema familiar, na cooperação do trabalho entre eles. É muito comum nestas comunidades rurais que os agricultores troquem ajuda de serviços na lavoura, uma família ajuda a outra.

O grupamento rural que é chamado de comunidade neste trabalho, foi chamado por Candido (2001) de bairro rural. O trabalho do autor, um estudo sobre a formação caipira do interior do estado de São Paulo, descreve que na sociedade caipira, a manifestação mais importante é o mutirão, ou seja, o agrupamento dos vizinhos de um determinado bairro para ajudar nas roçadas e plantações. Assim, é solucionado o problema da mão-de-obra, suprindo as limitações da atividade individual ou familiar.

As observações livres feitas neste trabalho e a experiência da pesquisadora como agricultora da região estudada, morando no campo até seus dezoito anos, levam a perceber a semelhança dos caipiras do Rio Bonito, estudados por Candido (2001) com os colonos (agricultores) do Sudoeste do Paraná. Estes, assim como aqueles, reúnem os vizinhos para ajudar nos trabalhos da lavoura, sem remuneração, apenas com o compromisso moral de retribuir quando o outro precisar e, o trabalho encerra-se com 
alimento e festa oferecidos por quem convocou o mutirão. No caso de Salto do lontra pode-se admitir que há um exercício, ainda que tímido, dos princípios de solidariedade e participação nestas comunidades rurais.

"Era eu mesmo, fui eu que fiz o plantio com ajuda dos filhos do vizinho" (Entrevistado Formiga).

“Aí nóis tudo trabalhemo né” (Entrevistado Lagarta).

“Toda família (...) é que depois para roçar eu sempre pago um pra roçar né, Por que é só roçada né. Dá uma roçada por ano" (Entrevistado Vespa).

“A família né, envolvia a família, a gente envolvia a família desde o plantio, depois pra limpar e daí acho que umas 2 vezes também fomos nós mesmo que podamos com alguns peões né e daí depois de um tempo prá cá que vem estas firma de fora que daí eles empreitam e a gente troca né, a erva em folha pela erva seca” (Entrevistada Joaninha).

A porção do trabalho que a maioria dos agricultores/as não realizam é a poda do erval. Esta é feita normalmente por terceiros, pessoas contratadas pelas empresas para fazer o serviço, mas, geralmente, a forma de realização da poda é inadequada, pois eles utilizam instrumentos como facão e foice que danificam a planta tornando o sistema predatório.

"A gente faz a limpeza e tal, mas sempre o pessoal que a gente vende é que faz a poda” (Entrevistado Fede-fede).

Conforme Andrade et al. (1999) e Mazuchowiski (1989), antigamente, retiravase $100 \%$ das folhas da planta na poda, tornando as plantas predispostas a alterações 
climáticas como geadas, chuvas e calor, causando ataque de microorganismos, sendo uma das causas de exaustão e redução das erveiras nativas. Atualmente, recomenda-se que a poda mais adequada deve ser feita com tesoura e serrotinho, pois a técnica da poda é importantíssima na produção total do erval e pode torná-lo improdutivo se for aplicada de forma predatória.

Nesse aspecto, pode-se concluir que os produtores de erva-mate de Salto do Lontra estão sendo prejudicados pelas podas realizadas por terceiros. Afinal, segundo relatos de um técnico da Emater, os próprios empreiteiros, aqueles que são contratados pelo comprador para cortar a erva-mate, não fazem uma poda de forma correta e assim, o erval acaba diminuindo a produção.

Em um plano de manejo para a cultura, caberia a realização de ações que habilitassem o próprio produtor de erva-mate para que ele mesmo pudesse fazer a poda do erval, juntamente com sua família.

\subsubsection{Perspectivas do agricultor sobre o futuro da erva-mate}

Fez-se questão de colocar a fala de todos os entrevistados para que se observe um dos aspectos que mais apareceu durante todas as entrevistas. Os agricultores de Salto do Lontra estão enfrentando sérios problemas com a questão econômica, o preço de mercado do produto erva-mate não agrada o agricultor e ele se sente desestimulado.

"Não é que eu parei. Está lá, mas se eu não aproveito, os filho, os netos aproveitam (...) Não, ele deve melhorar (o preço) porque eu tenho informa ali em (...) pra cá de Curitiba, Prudentópolis. A 7/8 anos atrás eles colhiam 80 milhões de Kg por ano de erva-mate nativa e hoje eles não colhe 20 milhões, então eles cortam demais, não é só judiar, tirar, tirar. Então eu acho que pode ainda valorizar... mais de uma poda por ano não. Todo mundo me fala: se fosse você 
arrancava e eu falo: não. Gastei, investi e agora deixo lá." (Entrevistado Louva-deus).

“A erva é um produto que dá futuro viu.. .porque muito em vez de deixar a terra em capoeira, planta erva, eucalipto, pinus (...) agora, acho que depois do erval formado é até melhorar um erval do que qualquer pinheiro ou eucalipto né. Porque depois de formado, de 2 em 2 anos dá produção e é uma planta que nunca termina, pois sempre tem como vender e as vezes a pessoa desiste porque não sabe, viu um ou outro falar que não tem saída e vão na onda né. Eu nunca precisei sair de casa para vender a erva, sempre vieram aqui." (Entrevistado Vespa).

“O erval não está exatamente parado, mas economicamente não compensa investir" (Entrevistado Fede-fede).

“Parada, parada, assim não, a gente continua, quando é época de cortar vem alguém de fora e a gente corta e troca né, mas não foi parado assim de destruir. O que nós plantamos naquela época está ali nos pés. E agora tem mais ali pra cima nos pinheiros que nasceu bastante, a gente vai deixar né, não é que liquidamos assim, só que a gente não se dedicou né porque aí tem que cuidar melhor (...)” (Entrevistada Joaninha).

“É, se tivesse um preço melhor, mas não chegamos a $R \$ 1,00$ a arroba...” (Entrevistado Borboleta). 
"Eu não parei. Mudei de sítio e destoquei umas partes. tem uns 2 alqueires de erva-mate, e onde for rala vou repovoar, vou plantar pinheiro no meio, alguma árvore e até frutífera por que daí aproveita a terra né. Se bem que a gente devia ter parado porque com a erva-mate porque de uns 4 a 5 anos pra cá a gente não tira a limpa dela, tá sem preço, só que se tirá, amanhã depois todo mundo tá tirando, ela vai voltar a ter preço.... Na minha opinião quem for plantar erva-mate precisa pega uma erva nativa né, ver da procedência, de onde vem a muda. O certo seria, porque depois o comprador quer uma erva boa. E de preferência plantar consorciada, se tiver algum mato ou árvore, deixe. Árvore, os galhos ficam por cima da erva e vai desbastando os galhos próximos a ela, a erva não se incomoda. Ela não gosta assim de um sinamão ou aquelas planta que mata o que tiver embaixo né. Então uns coqueiros, umas frutas vai bem, faz bem até para os passarinhos né” (Entrevistado Besouro).

"Eu parei porque não tem retorno, então ninguém compra, inclusive tá meio abandonado, eu devo Ter lá uns 2500 pés, mas tá no meio do mato (...) estou esperando melhorar mesmo porque, não sei se é verdade ou não, diz que a erva é bom deixar no meio do mato, então aproveitei... ah!ah!ah! não dá retorno, então a gente não tem como investir em cima. Eu andei cuidando uns dois três anos, era caprichado, mas depois que eu vi que não dava retorno eu abandonei. Agora faz uns dois anos que eu não podo mais... Eu quero dizer que acho que devia ter mais incentivo e lugar para vender esta erva, para ter um lucrinho a mais. Aqui no nosso município muita gente plantou e tá até arrancando por que não tem 
mercado pra erva. Se tivesse um mercado, vamos dizer que fosse 2 reais cada pé, com 2500 pé, são 5 mil, já dá uma rendinha boa...mas a gente oferece, os cara fala que vem buscar e nem vem. Eles perguntam se é nativa ou plantada, $e$ plantada eles não têm interesse. Mesmo aqui, tinha aquele viveiro que era uma maravilha, o cara produzia $500 \mathrm{mil}$ mudas por ano e aí ele acabou vendendo a propriedade, indo embora e acabou tudo. É uma pena, era um viveiro bem cuidado, produzia boas mudas.. .então aqui tá mais pra zero a procura da erva."(Entrevistado Formiga).

"É uma coisa que é economicamente inviável, são 50 centavos a arroba, não vale nada... Primeiro, uns ano atrais, a pessoa ficava em volta do pé de erva alisando e hoje não paga a pena nem a pessoa plantar um pé de erva." (Entrevistado Borboleta).

Ocorrem problemas de comercialização do produto, pois as empresas que compram a erva-mate em folha preferem a erva-mate nativa e não se disponibilizam a recolher pouca quantidade de erva-mate, Assim, se o agricultor tiver poucos quilos para vender, não conseguirá atrais os compradores, o transporte se torna caro demais.

Porém, mesmo assim aparecem, nos registros das entrevistas, esperanças de que a situação melhore:

“(...) Então não vale a pena né (...) mas, derrepente, quem sabe tem algum incentivo de alguma autoridade que a gente vê assim que vale a pena plantar mais, a gente até pode futuramente voltar a se dedicar com isso. Mas tem que ter incentivo da autoridade, dos nossos governantes né" (Entrevistada Joaninha) 
“(...) todas as coisas, ela é uma árvore que eles industrializa e acho que uma hora ela melhora. Às vezes eu acho que ainda vai ser um bom negócio. Eu acho que quem tem terra e plantar, eles não se arrepende não. Acho que amanhã, depois vai dar dinheiro."( Entrevistado Pulgão).

Os problemas de comercialização e preço da erva-mate não se restringem ao município de Salto do Lontra e há outros fatores que contribuem para a decadência da erva-mate na região.

Segundo Maccari Júnior. et al. (2003), os trabalhos de pesquisa e extensão visando a sustentabilidade para a atividade ervateira devem considerar o perfil do setor ervateiro, suas características e suas dimensões, levando em consideração características do setor em cada região e as especificidades de cada município. O autor faz uma colocação importante: como dimensionar recursos financeiros, físicos e humanos, para dar atendimento às comunidades e empresas que trabalham com erva-mate se não se sabe sua precisa localização, dimensão e reais necessidades?

Na Argentina, a produção de erva-mate sempre superou a demanda interna pelo produto, levando uma oferta de erva-mate excedente, pois os ervais argentinos plantados a pleno sol têm uma produtividade maior que os ervais plantados no Brasil nas mesmas condições. Fato que se dá pelo maior profissionalismo dos produtores e também aos subsídios dados pelo governo.

Mas mesmo assim, havia uma disparidade muito grande entre o peso argentino e o dólar, tornando o produto argentino muito caro para o mercado brasileiro. Entretanto, com a crise da Argentina em 2002 e fatores associados, tal paridade desapareceu e o produto argentino ganhou os mercados brasileiros, fazendo com que o produto nacional passasse a ser comercializado em menor volume e a preços inferiores aos anos anteriores. A questão é problemática no setor, as dificuldades são de cunho econômico, mas também de caráter tecnológico na questão do manejo dos ervais pelos produtores. 


\title{
5 CONSIDERAÇÕES FINAIS
}

\begin{abstract}
"Um dos melhores caminhos é re-aprender o conhecimento ecológico e os princípios sustentáveis que nossa sociedade perdeu. Isto pode se tornar realidade ao ouvir os povos do planeta que ainda sabem quando os pássaros fazem ninhos, os peixes migram, formigas aglomeram-se, girinos desenvolvem pernas, o solo sofre com a erosão e plantas raras produzem sementes e cujas as visões mundiais manifestam as ecologias e éticas da sustentabilidade".
\end{abstract}

Darrel Posey

No início deste trabalho, a hipótese principal era de que os problemas dos agricultores de Salto do Lontra com a erva-mate estavam ocorrendo porque haviam implicações de ordem fitossanitárias. No entanto, no decorrer do trabalho pode-se perceber com clareza que, neste município, as pragas da cultura causam baixíssimo impacto na produção, não há grandes perdas e não é por isto que os produtores estão deixando a cultura. A gama de aspectos que circundam o problema é bem mais ampla do que se imaginava.

O produtor de erva-mate observa, no seu dia-a-dia, a presença de insetos em suas plantações de erva-mate e em outras também, conhece alguns insetos que causam danos à erva-mate e outros que não afetam suas plantações. Isso foi observado quando comparado o conhecimento dos/as agricultores/as sobre os insetos com a literatura a respeito. 
Nas coletas realizadas observou-se a presença de 68 famílias de insetos nos ervais onde foram colocadas as armadilhas e, muitos destes insetos podem apresentar-se como pragas, enquanto outros podem mostrar-se como inimigos naturais.

A maioria dos entrevistados vê nos insetos uma imagem negativa, defendendo a sua eliminação. Entretanto, alguns agricultores demonstram um conhecimento mais amplo destes organismos observando sua relevância no ambiente de uma forma mais positiva.

Em linhas gerais, partiu-se de um problema fitossanitário com insetos praga, para chegar a um problema econômico. Quando aparece um problema de ordem econômica, antes aparecem os fatores que o causam. Para que um produto seja bem aceito no mercado pelo consumidor, ele precisa ter garantia de qualidade. E este é um problema da erva-mate plantada no Brasil.

Não é possível generalizar a situação e dizer que todos os ervais plantados são mal cuidados, mas no caso dos ervais de Salto do Lontra, PR, observou-se que o manejo da cultura é inadequado e precário devido ao restrito conhecimento do produtor sobre o assunto. Falta apoio das entidades locais como a Secretaria de Agricultura e a Emater.

Para compreender a atuação das políticas públicas do estado do Paraná no município de Salto do Lontra seria necessário um amplo estudo que compreendesse tanto intervenções realizadas pelo governo como também pelas ONGs e entidades do setor privado que se destinem a atender objetivos públicos.

No caso da erva-mate, no município de Salto do Lontra, o discurso da extensão rural não se concretizou na prática, porém isto não significa que o mesmo acontece em todos os projetos de extensão e políticas públicas no estado do Paraná. Os programas de incentivo à agricultura familiar no Paraná são bastante difundidos, como é o caso dos laticínios na região sudoeste e mais recentemente os produtos orgânicos. Para avaliar a efetiva ação destes projetos na melhoria da qualidade de vida do agricultor e como formas sustentáveis de produção, será necessária uma análise mais complexa e a longo prazo destes projetos.

Um programa de política pública para a cultura da erva-mate como alternativa de desenvolvimento rural local poderia seguir os mesmos passos abordados por uma equipe 
de pesquisadores da UFRJ com apoio do PRONEX em um plano de políticas públicas para o município de Rebouças no Paraná. Tais passos seriam: levantar indicadores e variáveis referentes aos componentes do sistema, à base técnica, à economia do sistema, às condições de vida dos agricultores/as, aos interesses atuais e expectativas futuras destes agricultores/as, conforme descreve Costa et al, (1999).

Outro problema local é o da comercialização do produto na região. Problema agravado pelo fato dos produtores trabalharem isoladamente, não havendo o mínimo de organização entre eles, apenas algumas trocas de serviços. Na hora de plantar e de vender, ocorrem ações isoladas e isto não fortalece a atividade. Como já mencionado neste texto, produtores do Rio Grande do Sul passaram pelos mesmos problemas e encontraram soluções se agregando, principalmente em cooperativas.

A Região Sudoeste do Paraná possui cooperativa agrícola mista, a qual não comercializa e não tem nenhuma atividade ligada à erva-mate. A prioridade regional são as grandes monoculturas, principalmente soja e milho e mesmo os pequenos e médios produtores, com pouca terra, que acabam aderindo a estes cultivos.

As vantagens que a erva-mate tem em termos ecológicos e também socioeconômicos precisam ser consideradas. Sabendo que cerca de 92,8\% do número de estabelecimentos rurais da Região Sudoeste do Paraná encontram-se em regime de agricultura familiar é inaceitável que se deixe perder a oportunidade de oferecer a estas famílias uma fonte de renda alternativa como a erva-mate.

O agroecosssitema da erva-mate apresenta vantagens ecológicas em relação à outras culturas, pois é possível implantar sistemas diversificados como o consorciamento de culturas agrícolas com a erva, aproveitando o espaço e contribuíndo para recuperação de terras marginais degradadas. Com a vantagem de não ser possível utilizar produtos químicos, garantido maior qualidade ao produto e à própria vida dos agricultores e do consumidor, bem como a conservação do ambiente de forma sustentável.

Mais do que conservar o ambiente de forma sustentável, é preciso fomentar a construção de uma sociedade sustentável na inclusão social,. Segundo Sorrentino (s/d) as políticas públicas devem fornecer o apoio necessário à valorização e a capacitação das 
iniciativas locais, optando por produtos e processos produtivos a serem fomentados para ocuparem o mercado interno e externo.

Se estas políticas fomentassem a atividade local dos produtores de erva-mate, estes teriam melhores condições de competir no mercado.

Porém, não será impondo ao agricultor um plano de manejo para a cultura que o problema se resolverá. O agricultor não é um receptor de informações, é alguém que pensa, que tem sua opinião e se ele não se sentir estimulado com as propostas, nada vai mudar. Por isto, acredita-se que o trabalho deva começar pela base, valorizando o conhecimento que ele tem do assunto e suas necessidades locais.

Quando os agricultores de Salto do Lontra falam sobre falta de incentivo, sentese a urgência de que alguém ou algum setor precisa desencadear uma ação local, para que não sejam eliminados os ervais e não se perca a oportunidade de proporcionar uma qualidade de vida melhor a estas famílias. Há um desejo implícito na fala deles e na expressão do olhar, um sentimento de angústia por ter investido em algo que não deu retorno financeiro. Mas como fazer e por onde começar para tentar resolver a situação, ainda não está bem claro.

Acredita-se que as contribuições etnoentomológicas podem auxiliar no plano de manejo, dentro da perspectiva da agroecologia, na qual a cultura da erva-mate se encaixa, no sentido de valorização e aproveitamento do etnoconhecimento, aliado ao conhecimento técnico para que os problemas enfrentados sejam resolvidos através do diálogo dos saberes e práticas. 


\section{REFERÊNCIAS BIBLIOGRÁFICAS}

ALtIERI, M. A. Agroecologia: as bases científicas da agricultura alternativa. Trad. de P. Vaz. Rio de Janeiro: PTA/FASE, 1989. 240p.

ALVES, L.F.A.; . BRANCALHÃO, R.M.C.; SANTANA, D.L.Q. Ocorrência de Baculovírus em lagartas de Perigonia lusca (Fabr.) (Lep., Sphingidae) no Brasil. Neotropical Entomology, v.30, n.3, p.493-494, set. 2001.

ALVES, L.F.A.; SANTANA, D.L.Q.; NEVES, P.M.O.J.; OLIVEIRA, R.C. Ácaros Fitófagos da erva-mate: Situação atual e perspectivas de controle. In: CONGRESSO SUL-AMERICANO DA ERVA-MATE, 2.; REUNIÃO TÉCNICA DA ERVAMATE, 3., Encantado, 2000. Anais. Porto Alegre: Ed. UFRGS, 2000. p. 39-42.

ALVES, L. F. A.; SILVA, E. R. L.; GASSEM, M. H.; ALVES, V. S.; GUZZO, E. C.; ROHDE, C. Ocorrência de Stethorus histrio (Coleoptera: Coccinellidae), predador do ácaro vermelho da erva-mate. In: CONGRESSO BRASILEIRO DE ZOOLOGIA 24. Itajaí, 2002. Anais (Compact disc). Itajaí: Ed. URI, 2002.

ANDRADE, F. M.; LINO, F. C.; SOMÕES, L.L. Diagnóstico da cadeia produtiva da Ilex paraguariensis St. Hill Erva-mate. http://www.unicamp/nipe/rbma/ervamate.html (18 junho 2003).

ANUÁRIO BRASILEIRO DA ERVA-MATE. Santa Cruz do Sul. Editora Gazeta, 1999. 64p. 
ANUÁRIO BRASILEIRO DA ERVA-MATE. Santa Cruz do Sul. Editora Gazeta, 2000. 79p.

ARDOINO, J. Abordagem multirreferencial (plural) das situações educativas e formativas. In: Barbosa, j. (Org.). Multirreferencialidade nas ciências e na educação. São Carlos, UFSCar, 1998. p.24-41.

AVÉ-LALLEMANT, R. Viagem pelo Sul do Brasil no ano de 1858. Trad. De Teodoro Cabral. Rio de Janeiro: Ed. Instituto do Livro. 1953, v.1, 152p.

BAGGIO, A. J.; STURION, J. A.; SCHREINER, H. G.; LAVIGNE, M. de. Consorciamento das culturas de erva-mate (Ilex paraguarienses a. St. Hilaire) e feijão (Phaseolus vulgaris L.) no sul do Paraná. Boletim de Pesquisa Florestal, n.4, p. 75-90, jun, 1982.

BECKER, H. S. Métodos de Pesquisa em ciências sociais. 2.ed. São Paulo: Hucitec, 1999.178p.

BERTI FILHO, E. Controle biológico dos insetos. Apostila da disciplina de controle biológico. Piracicaba: Departamento de entomologia e zoologia agrícola, curso de pós-graduação em entomologia. 2001.80p.

BERTI FILHO, E.; KRUGNER, T.L. Manejo integrado de pragas e doenças em povoamentos de Eucalyptus no Brasil. Silvicultura, v.41, p.41-43, 1986.

BITTENCOURT, G. A. Sistema cresol de cooperativas de crédito rural: uma experiência de economia solidária entre os agricultores familiares. In: SINGER P.; SOUZA, A. R. (Org.). A economia solidária no Brasil: a autogestão como resposta ao desemprego. São Paulo: Contexto. 2000. p193-216. 
BORROR, D. J., DELONG, D. M. Introdução ao estudo dos insetos. São Paulo: Edgar Blucher. 1969. 653p.

BRADLEY, J. Methodological issues and practices in qualitative research. Library Quarterly, v.63, n. 4, p. 431-449, oct. 1993

BRANDÃO, C. R. O afeto da terra. Campinas: Unicamp, 1999. 175p.

BUTTEL, F. H., G. W. GILLESPIE, JUNIOR., R. JANKE, B. CALDWELL, M. SARRANTONIO. Reduced-input agricultural systems: rationale and prospects. Journal of Alternative Agriculture, v. 1, p. 58-64, 1986.

CANDIDO, A. Os Parceiros do Rio Bonito. 9. ed. São Paulo: Ed. 34, 2001, 376p. (Coleção Espírito Crítico).

CAMPOS, M. D. Etnociência ou etnografia de saberes, técnicas e práticas?. In: AMOROZO, M. C. M, MING, L. C., SILVA, S. M. P DA (Ed). MÉTODOS DE COLETA E ANÁLISE DE DADOS EM ETNOBIOLOGIA, ETNOECOLOGIA E DISCIPLINAS CORRELATAS. Rio Claro: UNESP, 2002. Anais. p 47-92.

CARSON, R. Primavera Silenciosa. Rio de Janeiro: Melhoramentos, 1962. 305p.

CARVALHO, I. C. de M. Qual Educação Ambiental? Elementos para um debate sobre educação ambiental popular e extensão rural. Revista Agroecologia e Desenvolvimento Rural Sustentável, v.2, n.2, p.43-51. abr/jun. 2001.

CHIARADIA, L. A.; MILANEZ, J. M. Atratividade de armadilhas coloridas a Gyropsylla spegazziniana (LIZER, 1917) (HOMOPTERA, PASYLLIDAE). Pesquisa Agropecuária Gaúcha, v.3, n.2, p. 183-185, 1997. 
CHIARADIA, L.A.; MILANEZ, J.M.; SABEDOT, S.M. Caracterização e Danos da Ampola-da-erva-mate. Agropecuária Catarinense, v.13, n.1, p.50-53, mar. 2000.

COSTA NETO, E. M. Introdução à Etnoentomologia: considerações metodológicas e estudo de caso. Feira de Santana: UEFS, 2000.1v.

COSTA NETO, E. M. Manual de etnoentomología. Feira de Santana: Zaragoza, 2002. v.4. 104p.

COSTA, S.G.da. A Erva-Mate. Curitiba: Coleção Farol do Saber, 1995. 132p.

COSTA, L. F. de C; MOREIRA, R. J.; BRUNO, R (Ed.). Mundo Rural e Tempo Presente. Rio de Janeiro: Mauad, 1999. 352p.

DE COLI, O.R.; SAINI, E.D. Insectos y acaros prejudiciales al cultivo de la yerba mate em la República Argentina. Montecarlo: INTA, 1992. 48p.

DIAGNÓSTICO SOCIAL E ECONÔMICO 2003. Instituto Paranaense de Desenvolvimento Econômico e Social. http://www.pr.gov.br/ipardes/pdf/diagnóstico_relatório.pdf (22 abril 2003)

DIEGUES, A. C. (Org.) Etnoconservação, novos rumos para a proteção da natureza nos trópicos. São Paulo: Hucitec, 2000. p.2-46. 290p.

DUNLAP; R. E.; BEUS, C. E. (Trad.) de BUENO, A. R. S. Agricultura convencional versus Alternativa: as raízes Paradigmáticas do Debate. 1990.1v. 
EHLERS, E. Agricultura sustentável: origem e perspectiva de um novo paradigma. São Paulo: Livros da Terra Editora, 1996.178p.

FERNANDEZ DIAZ, C.Y. Perspectivas del manejo integrado de plagas em yerba mate. In: CONGRESSO SUL-AMERICANO DA ERVA-MATE, 1. REUNIÃO TÉCNICA DA ERVA-MATE, 2., CURITIBA, 1997. Anais. Curitiba: Ed. UFPR, 1997. p. 371-390.

FERNANDEZ DÍAZ, C. I.; TRICIO, A E.; MORAWICKI, P. M. Insectos asociados al cultivo de yerba mate (Ilex paraguariensis, A. ST. HILL.). In: CONGRESSO SULAMERICANO DA ERVA-MATE, 2.; REUNIÃO TÉCNICA DA ERVA-MATE, 3., Encantado, 2000. Anais. Porto Alegre: Ed. UFRGS, 2000. p 46-49.

FLECHTMANN, C.H.W. Ácaros de importância agrícola. 5.ed. São Paulo: Nobel, 1985. 189p.

FREIRE, P. Extensão ou comunicação. Rio de Janeiro: Paz e Terra. 1971. 93p. (Série Ciência e Informação, 6)

FURTADO, C. M Formação Econômica do Brasil. 11 ed. São Paulo: Nacional, 1971. 248p.

GALLO, D.; NAKANO, O.; SILVEIRA NETO, S.; CARVALHO, R.P.L.; BAPTISTA, G.C. de; BERTI FILHO, E.; PARRA, J.R.P.; ZUCCHI, R.A.; ALVES, S.B.; VENDRAMIM, J.D.; MARCHINI, L.C.; LOPES, J.R.S.; OMOTO, C. Entomologia Agrícola. Piracicaba: FEALQ, 2002. 930p.

GEERTZ, C. O saber local, novos ensaios em antropologia interpretativa. 3. ed. Petrópolis: Vozes, 1997. 366p. 
GLIESSMAN, S. R. Agroecologia: processos ecológicos em agricultura sustentável. Porto Alegre: Ed. Universidade/UFRGS, 2000. 653p.

GRAZIANO DA SILVA, J. Estrutura agrária e produção de subsistência na agricultura brasileira. São Paulo: Hucitec, 1980. 240p.

GRAZIANO NETO, F. Questão agrária e ecologia, crítica da moderna agricultura. São Paulo: Brasiliensis, 1986. 154p.

GRIGOLETTI JÚNIOR, A.; SANTOS, A.F.dos; AUER, C.G.. Doenças da erva-mate no Brasil. In: CONGRESSO SUL-AMERICANO DA ERVA-MATE, 1; REUNIÃO TÉCNICA DA ERVA-MATE, 2. Curitiba, 1997. Anais. Curitiba: Ed. UFPR, 1997. p.359-369.

GUZMÁN, E.S. A perspectiva sociológica em Agroecologia: uma sistematização de seus métodos e técnicas. Revista Agroecologia e Desenvolvimento Rural Sustentável, v.3. n.1, p.18-28, jan/mar. 2002.

HAFERNIK JUNIOR., J. E. Tretas to invertebrat biodiversity: inplications for conservation strategies. In: FIEDLER,P. L.; AND, K, J.; SUBODH (Ed). Conservation biology- The teori ens practice of nature conservation and managment. New Cork: Chapman and may, 1992. p. 171-195.

HAGEN, K.S. The significance of predaceous Coccinellidae in biological and integrated control of insects. New York: Academic Press, 1974. p.25-44.

HAGUETTE, T. M. Metodologias qualitativas na Sociologia. Rio de Janeiro: Vozes, 1992. p.52-92. 
HOGUE, C. L. Cultural entomology. Annual Review of Entomology, v.32. p.181-199, 1987.

HODEK, I. Biology of Coccinellidae. Prague: Academic of Sciences, 1973. 260p.

IBGE. Censo Agropecuário 1995/1996. http://www.ibge.br. (12 maio 2003)

KELLERT, S. R. Values and perceptions of invertebrates. Conservation Biology, v. 7, n.4: p.845-853, 1993

KELLERT, S. R. The value of life. Irland Press: Shearwater Books, 1996. p.9-33.

LAPASSE, G. Da multirreferencialidade como "bricolagem". In: BARBOSA, J.G. (Org.). Multirreferencialidade nas ciências e na educação. São Carlos: UFSCar. 1998. p.126-148.

LEFF, E. Agroecologia e saber ambiental. Revista Agroecologia e Desenvolvimento Rural Sustentável, v.3, n.1,.p.36-51, jan/mar, 2002.

LÉVI-STRAUSS, C. O uso das plantas silvestres da América do sul tropical. In: RIBEIRO, B.G. (Ed.). Suma etnológica brasileira. 1. Etnobiologia. Petrópolis: Vozes/FINEP, 1987, p. 18-41.

LINHARES, T. História econômica do mate. Rio de Janeiro: José Olympio: Editora. Coleção documentos brasileiro, 1969.522p.

MACCARI JUNIOR, A.; MZUCHOWSKI, J. Z.; QUEIROZ, M. R. ; RUCKER, N. G. A. Sustentabilidade da atividade ervateira - a necessidade de caracterização do setor industrial ervateiro paranaense. www.pr.gov.br/colepar/seab (20 abril 2003). 
MACEDO, S. M. A etnopesquisa crítica e multirreferencial nas ciências humanas e na educação. Salvador: EDUFBA, 2000. 297p.

MAGURRAM, A. E. Ecological diversity and its measurement. New Jersey: Princiton University, 1988. 179p.

MAJER, J. D. The conservation and study of invertebrates in remnantes of native vegetation. In: SAUNDERS, D. A.; G. W. ARNOLD, A. A.; BURBIDGE, A. J. M. HOPKINS (Ed.). Nature conservation: the role of remnants of native vegetation. Sydney: Surrey Beaty, 1987. p.333-335.

MARQUES, J. G.W. Pescando Pescadores: Ciência e Etnociência em uma perspectiva Ecológica. 2 ed. São Paulo: Ed. NUPAUN-USP, 2001 258p.

MARQUES, J. G. W. O olhar (des) multiplicado. O papel do interdisciplinar e do qualitativo na pesquisa etnobiológica e etnoecológica. In: AMOROZO, M. C. M, MING, L. C., SILVA, S. M. P DA (Ed). MÉTODOS DE COLETA E ANÁLISE DE DADOS EM ETNOBIOLOGIA, ETNOECOLOGIA E DISCIPLINAS CORRELATAS. Rio Claro: UNESP, 2002. Anais. p.31-45.

MAZUCHOWSKI, J.Z. Manual da erva-mate. Curitiba: EMATER. 1989. 104p.

MAZUCHOWSKI, J. Z. Alternativas para o incremento da produtividade de ervais nativos. In: CONGRESSO SUL-AMERICANO DA ERVA-MATE, 2.; REUNIÃO TÉCNICA DA ERVA-MATE, 3., Encantado, 2000. Anais. Porto Alegre: Ed. UFRGS, 2000. p. 6-9.

MAZUCHOWSKI, J.Z.; RUCKER, N.G. de A. Diagnóstico e alternativas para a erva-mate Ilex paraguariensis. Curitiba: Secretaria de Estado da Agricultura e do Abastecimento do Paraná. Departamento de Economia Rural, 1993. 141 p. 
MEDRADO, M. J. S.; LOURENÇO, R. S.; MOSELE, S. H.; WACZUK, A. J. Sistema de poda de formação da produtividade da erva-mate (Ilex paraguariensis) ST. HIL.), no município de áurea, RS. Revista Perspectiva, v. 24, n.88, p.63-66. 2000.

MERCANTE, M. S. A interconexão entre saberes, práticas e percepções: o mediador entre cultura e natureza http://www.trabalhodeteoria.etno.htm (01 maio 2002).

MINAYO, M.C.S. (Org.). Pesquisa Social - teoria, método e criatividade. 14.ed. Petropolis:Ed. Vozes, 1999. 80p.

MOHAN, S.; KARUPPUCHAMY, P.A. Potential predator for sorghum mite, Oligonychus indicus (Hist). Current Science, v.56, n.10, p.845-846,1987.

McMURTRY, J.A.; JHONSON, H.G. An ecological study of the spider mite Oligonychus punicae (Hirst) and its natural enemies. Hilgardia, v.37, n.11, p.363402, 1966.

McMURTRY, J.; HUFFAKER, C.B.; VAN DE VRIE, M. Tetranychid enemies: Their biological characteres and the impact of spray practices. Hilgardia, v.40, n.11, p.351-357, 1970.

MONTOYA, L. J. V.; MAZUCHOWSKI, J. Z. Estado da arte dos SAF's na Região Sul do Brasil. In: CONGRESSO BRASILEIRO SOBRE SISTEMAS AGROFLORESTAIS. Porto Velho-RO, 1994. Anais. Colombo: EMBRAPA. 1994. p.77-96.

MORIN, E. Os sete saberes necessários à educação do futuro. São Paulo: UNESCO. 2000. 118p. 
NEVES, J. L. Pesquisa qualitativa-características, usos, possibilidades. Caderno de Pesquisas em Administração, v.1, n.3, p.1-5, 1996.

NOGUEIRA, D. Pesquisa Social: introdução às suas técnicas. São Paulo: ed. Nacional, 1975. p.111-136.

ODUM, E. P. Ecologia. Rio de Janeiro: Ed. Guanabara. 1988. 438p.

PACHECO, J. M. Etnoentomologia: o que é um inseto? Informativo da Sociedade Entomológica do Brasil, v.26, n.2, 2001. p.1-5.

PACHECO,J. M.; SCATOLINI, D. GONÇALVES, P. A. DE S. Percepção dos insetos pelos pós-graduandos da UFSCar. São Carlos: Universidade Federal de São Carlos, 1998.1v.

PASCHOAL, A. D. Pragas, praguicidas e a crise ambiental: problemas e soluções. Rio de Janeiro: FVG, 1979. 210p.

PATTON, M. Qualitative evaluation methodos. Beverly Hills, CA: Sage, 1980. 381p.

PENTEADO, S.R.C. Principais pragas da erva-mate e medidas alternativas para o seu controle. In: WINGER, H.; FERREIRA, A.G.; MARIATH, J.E.A.; TARASCONI, L.C. Erva-mate: Biologia e cultura no Cone Sul. Porto Alegre: Ed. UFRGS, 1995. p.109-120.

PENTEADO, S.R.C.; IEDE, E.T.; LEITE, M.S.P. Pragas da erva-mate: perspectivas de controle. In: CONGRESSO SUL-AMERICANO DA ERVA-MATE, 2.; REUNIÃO TÉCNICA DA ERVA-MATE, 3., Encantado, 2000. Anais. Porto Alegre: Ed. UFRGS, 2000. p. 27-34. 
POSEY, D. A. Etnobiologia: teoria e prática. In: RIBEIRO, B. G. (Ed.) Suma etnológica brasileira. 1. Etnobiologia. Petrópolis: Vozes/FINEP, 1986 .p.2-15.

POSEY, D. A. Etnoentomologia de tribos indígenas da Amazônia. In: RIBEIRO, D. Ed. Suma etnológica brasileira. 1. Etnobiologia. Petrópolis: Vozes/FINEP. 251-272p. 1987a.

POSEY, D. A. .Etnobiologia e Ciência de Folk: sua importância para a Amazônia. Tübinger Geographische Studien, v.94, p.95-108, 1987b.

PRATES, H.S. Ácaros-pragas em citros e seu controle. Correio Agrícola, v.2, p.553554, 1983.

PRAT KRICUN, S. D. (Coord.) Informe sobre investigaciones realizadas no período de 1984-85. Missiones: INTA, 1986. 36p. (Miscelania,15).

PREFEITURA MUNICIPAL. Relatório Procaxias. Salto do Lontra. v.1, 1998. 17p.

PRIMAVESI, A. Agroecologia: ecosfera, tecnosfera e Agricultura. São Paulo: Nobel. 1997.199p

PRIMACK, R. B.; RODRIGUES E. Biologia da Conservação. Londrina: Ed. Midiograf, 2001. 328p.

PRICE, P. W. Insect Ecology. New York: John Wiley, 1984.1v.

RAWORTH, D.A. Development, larval voracity, and greenhouse releases of Stethorus punctillum (Coleoptera: coccinellidae). The Canadian Entomologist, v.133, p.721724, 2001. 
ROSA, V. Abordando as relações agricultura e meio ambiente no ensino formal, através da educação ambiental - considerações a partir de um caso. Piracicaba, 2001. 260p. Dissertação (Mestrado) - Escola Superior de Agricultura “Luiz de Queiroz”, Universidade de São Paulo.

ROTT, A.S.; PONSONBY, D.J. The effects of temperature, relative humidity and host plant on the behaviour of Stethorus punctillum as a predator of the two-spotted spider mite, Tetranychus urticae. BioControl, v.45, p.155-164, 2000.

RUCKER, N. G. de A. Análise do agronegócio da erva-mate Curitiba: Secretaria de Estado da Agricultura e do Abastecimento do Paraná. Departamento de Economia Rural, 1997, 38 p.

RUCKER, N.G.A.; MACARI JR. A.; ROCHA JR. W.F. Agronegócio da erva-mate no estado do Paraná: diagnóstico e perspectivas para 2003. Secretaria da Agricultura e Abastecimento do Estado do Paraná. www.pr.gov.br/colepar/seab/ (15 maio 2003).

SANTOS. B. S. Para um novo senso comum: a ciência, o direto e a política na transição paradigmática. A crítica da razão indolente: contra o desperdício da experiência. 3 ed. São Paulo: Cortez. 2001. v.2, 415p.

SANTOS, B. S. (Org.) Reinventar a emancipação social: novos manifestos. Produzir para viver: os caminhos da produção não capitalista. Rio de Janeiro: Civilização Brasileira, 2002. v.2, 514p.

SINGER, P. A recente ressureição da economia solidária no Brasil, p 83-129. In: SANTOS, B. S. (Org.) Reinventar a emancipação social: novos manifestos. Produzir para viver: os caminhos da produção não capitalista. Rio de Janeiro: Civilização Brasileira, 2002. v.2, 514p. 
SILVA, M. R. A sensibilização e o envolvimento em trabalhos com agroecossistemas biodiversos orientados pela sucessão natural no município de Barra do Turvo/SP Um estudo de caso. Relatório de qualificação (Mestrado).Universidade de São Paulo, 2001.155p.

SOARES, C.M.S. Flutuação Populacional, Aspectos Comportamentais e Levantamento de Inimigos Naturais de Hedypathes betulinus (Klug, 1825) (Coleoptera: Cerambycidae) em um Povoamento Puro de Erva-Mate (Ilex paraguariensis St. Hil.). Curitiba: 1998. 71p. Tese (Doutorado). Universidade Federal do Paraná.

SOARES, C.M.S.; IEDE, E.T. Perspectivas para o controle da broca-da-erva-mate Hedyphates betulinus (Klug, 1825) (Coleoptera: Cerambycidae). In: CONGRESSO SUL AMERICANO DA ERVA-MATE, 1.; REUNIÃO TÉCNICA DO CONE SUL SOBRE A CULTURA DA ERVA-MATE, 2., Curitiba, 1997. Anais. Colombo: EMBRAPA, CNPF, 1997. p.391-400.

SORRENTINO, M. Desenvolvimento sustentável e participação: algumas reflexões em voz alta. Piracicaba. (s.d). 4p.

SPEIGHT, M.R.; HUNTER, M.D.; WATT, A.D. Ecology of insects: Concepts and Applications. Ne York: Blackwell Science, 1999. p.227-294.

SPOSATI, A. Movimentos utópicos da contemporaneidade. In: SORRENTINO, M. Ambientalismo e participação na contemporaneidade. São Paulo: EDUC/FAPESP, 2001, p. 11-40.215p.

STEWART, I. A realidade irreal da imaginação matemática. Os números da natureza. Rio de janeiro: Rocco, 1995. 
TORMEN, M. J. Economia ervateira brasileira. In: WINGE, H.; FERREIRA, A.G.; MARIATH, J.E.; TARASCONI, L.C. Erva-Mate: biologia e cultura no Cone-sul. Porto Alegre: Ed. Universidade/UFRGS, 1995.p.27-40.

TRUJILLO, M.R. Agroecosistema yerbatero de alta densidad: plagas y enemigos naturales. In: WINGE, H.; FERREIRA, A.G.; MARIATH, J.E.; TARASCONI, L.C. Erva-mate: biologia e cultura no Cone Sul. Porto Alegre: Ed. UFRGS, 1995. p.129134.

WILSON, E. O. Diversidade da vida. São Paulo: Companhia das letras, 1992. 447p. 